$$
\begin{gathered}
\text { UNIVERSIDADE DE SÃO PAULO } \\
\text { INSTITUTO DE FÍSICA DE SÄO CARLOS } \\
\text { DEPARTAMENTO DE FISICA E INFORMÁTICA }
\end{gathered}
$$

\title{
ELABORAÇÃO DE UM MATERIAL PARADIDÁTICO DE FÍSICA: TEXTOS E EXPERIMENTOS
}

Alessandra Riposati Arantes

Dissertação apresentada ao Instituto de Física de São Carlos, da Universidade de São Paulo, para obtenção do título de Mestre em Ciências: Física Aplicada.

USPIIFSC/SBI

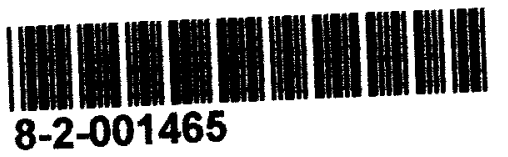

Orientador: Prof. Dr. Luiz Antonio de Oliveira Nunes 
Arantes, Alessandra Riposati

Elaboração de um material paradidático de física: Textos e Experimentos/Alessandra Riposati Arantes.-São Carlos, 2002.

$108 p$.

Tese (Mestrado) - Instituto de Física de São Carlos, 2002.

Orientador: Prof. Dr. Luiz Antonio de Oliveira Nunes

1.Ensino de Física. 2. Livros. I. Título 
MEMBROS DA COMISSÃO JULGADORA DA DISSERTAÇÃO DE MESTRADO DE ALESSANDRA RIPOSATI ARANTES, APRESENTADA AO PROGRAMA DE PÓS-GRADUAÇÃO EM FÍSICA, ÁREA DE CONCENTRAÇÃO FÍSICA APLICADA, DA UNIVERSIDADE DE SÃO PAULO, EM 15/03/2002.

\section{O M I S S Ã O J U L G A D O R A:}

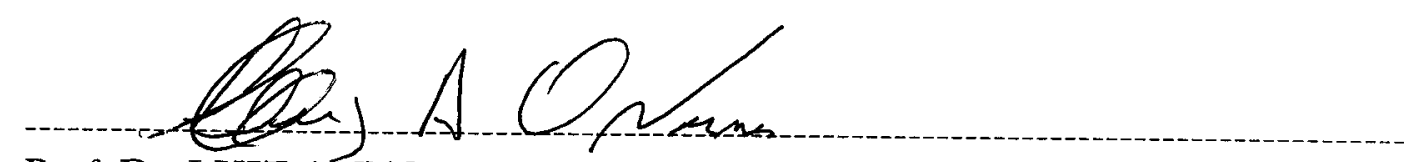

Prof. Dr. LUIZ ANTONIO DE OLIVEIRA NUNES(Orientador) - IFSC/USP

$\frac{\text { Qeatin Rharem }}{\text { Profa. Dra. BEATRIZ ALVARENGA - UFMG }}$

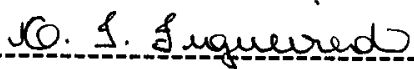

Profa. Dra. MARIANGELA TASSINARI DE FIGUEIREDO - IFSC/USP 
Dedico este trabalho aos meus pais

Américo e Ima. 


\section{Agradecimentos}

Quero agradecer aqui às pessoas que muito me ajudaram neste trabalho. Pelo apoio, paciência e orientação, sou grata ao meu orientador Luiz Antônio, a Glaucia Costa pelo auxílio incondicional, ao professor Tito Bonagamba, Josimar Sartori, Thaís e à Renata Siqueira pela elaboração da editoração dos livros.

Aos amigos de toda hora que tornaram essa fase da minha vida mais amena: Tânia, Daniel, Acácio, Sandro, Luiz Fernando (Feto), Andressa, Gercina, Marcel Godoy, Thaís Gonçalves, Andréa, Cynthia e Luciara.

A Capes pelo apoio financeiro.

E por fim, à minha familia que sempre me incentivou e apoiou em todos os momentos. 


\section{ÍNDICE}

RESUMO.

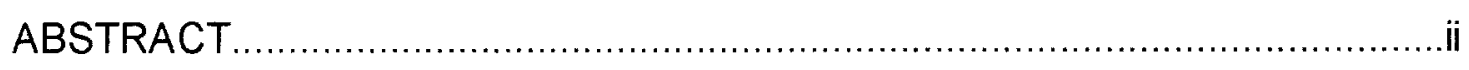

1 - INTRODUÇÃO

2 - O TRABALHO

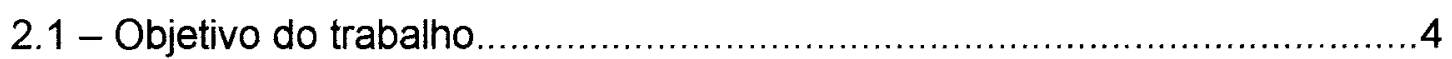

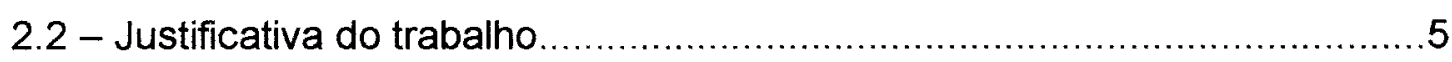

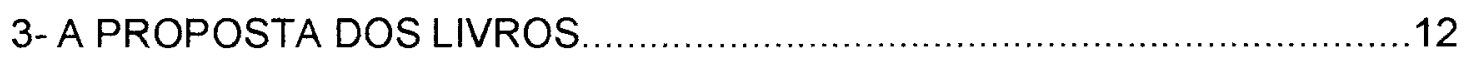

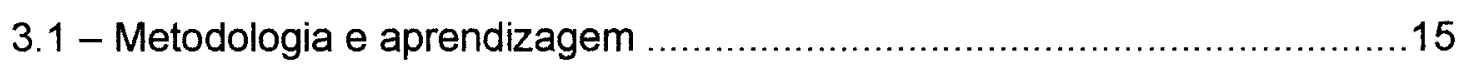

4- DESCRIÇÃO DOS LIVROS

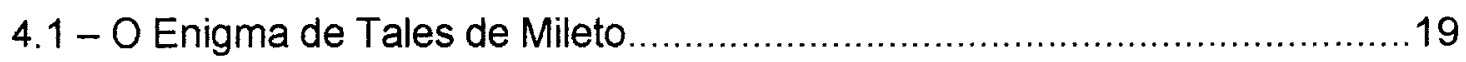

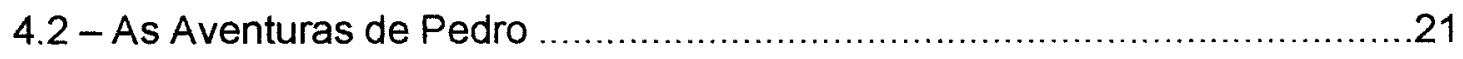

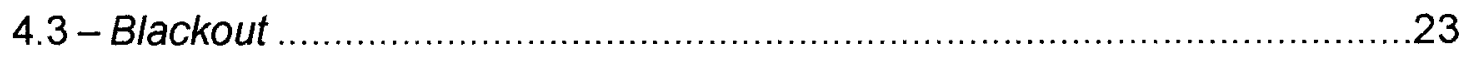

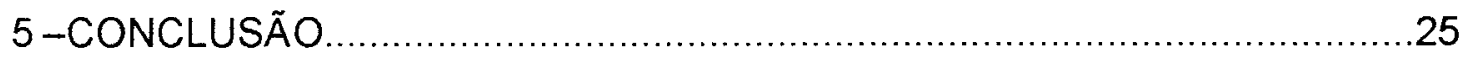

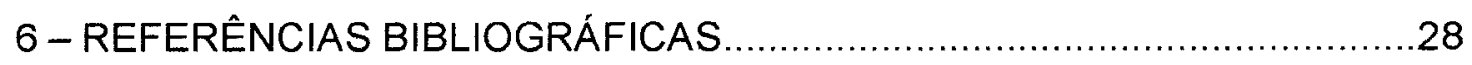

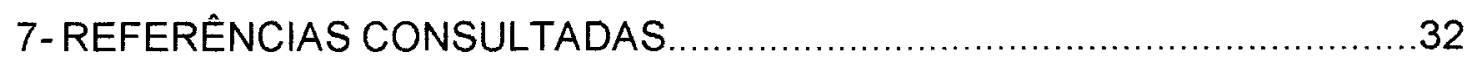

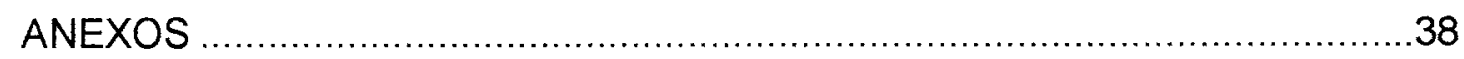




\section{RESUMO}

Este trabalho consiste na elaboração de três livros paradidáticos e, tem como público alvo pessoas interessadas em conhecer um pouco de ciência. Vale mencionar que os livros em questão servem como suporte aos livros didáticos.

O conteúdo da obra é apresentado por meios de questionamentos acerca de fenômenos físicos que quatro adolescentes fazem entre si. Quando não conseguem esclarecer esses fenômenos por si só, as personagens procuram um site, o qual conduzirá toda a trama, sempre respondendo o necessário e propondo atividades com as quais serão esclarecidas todas as dúvidas. No decorrer da narrativa são inseridos dados históricos pelas próprias personagens. Uma outra preocupação foi a de apresentar atividades que foram rigorosamente testadas, de forma que qualquer pessoa que se disponha a realizar algum experimento não se frustre com resultados absurdos. Todas as atividades são propostas com materiais simples e de baixo custo, tornando-se mais acessiveis.

Nessa dissertação serão apresentados livros cujos temas são: eletrostática; eletricidade dinâmica e eletromagnetismo.

Para comprovar a viabilidade desses materiais, os livros foram apresentados a adolescentes e adultos com o intuito de reproduzirem sozinhos as experiências, atividade que nos proporcionou a reformulação de alguns dados e, assim, a obtenção de resultados positivos. 


\begin{abstract}
This work is based on the confection of three paradidactic books dedicated to people interested in learning a little more about science. In this sense, it is worth noting that such books give support to didactic ones. The books' contents are presented by the questioning of physical phenomena by four adolescents. The idea is that whenever the adolescents are not able to clarify the concepts by themselves, they consult an internet site, which leads them to the right ideas and concepts by proposing activities or directly answering questions. As the narrative is done, characters present historical data pertinent to the topics. During the development of the work, a major concern of the authors was to present rigorously tested activities so that any person willing to realize the experiments doesn't get frustrated by absurd results. The activities are proposed with simple and inexpensive materials, which are easily accessible. The themes of the books are: electrostatic, dynamic electricity and electromagnetism and to prove the effectiveness of the collection, the books were presented to adolescents and adults which were encouraged to reproduce the experiments. By analyzing the results of such contact to the public, the quality of the work was enhanced.
\end{abstract}




\section{1- INTRODUÇÃO}

A história tem nos mostrado que o homem sempre procurou aprimorar os seus meios de comunicação. Tal anseio reflete a necessidade do ser humano em procurar informações e compartilhá-las com seus semelhantes. Por essa razão, entramos no século XXI dominados pelos meios de comunicação como: a televisão, o livro, o rádio e a internet. Nesse contexto, ainda perdura a extrema importância e eficácia do livro como destaque na formação do intelecto das pessoas, pela vantagem de guardar lembranças que o tempo não destrói, por divulgar informações a pessoas separadas no espaço e no tempo, e pela flexibilidade de ser transportado para todos os lugares.

$\mathrm{Na}$ época em que vivemos, os livros encontrados para o ensino de ciências podem ser analisados sob os aspectos didáticos ou paradidáticos. Os primeiros são utilizados como guia pelos professores, sendo ainda empregados como principal instrumento para as atividades desenvolvidas em sala de aula. Os profissionais da área o selecionam como um livro que contém o conteúdo básico desejável para ministrar a disciplina a que se propõe oferecer. Já os alunos o acompanham como fonte essencial para seus estudos. Portanto, não é exagero defini-los, como PAIVA (2001) o faz de, "manual do conhecimento". Quanto aos livros paradidáticos, estes são utilizados como apoio aos livros didáticos, explorando temas de maneira aprazivel e aprofundada, visto que, o conhecimento a ser transferido normalmente não emprega 
um formalismo matemático e sim, a discussão dos conceitos. É provável que esse motivo, seja responsável pela grande procura que vêm despertando, como nos demonstra a reportagem da folha de São Paulo, segundo a qual "Eles têm sido muito utilizados por alunos do ensino médio, até mesmo na preparação para o vestibular" (SILVA, 2001).

O presente trabalho tem como objetivo mostrar uma proposta para o livro paradidático de física, não muito comum. O trabalho é apresentado por meio de uma narrativa ficcional, na qual estão inseridos experimentos simples e de baixo custo, onde foram priorizadas as interpretações dos fenômenos físicos ocorridos nos mesmos.

Para a elaboração dessa obra, tivemos como motivação a carência desse material no mercado, assim como freqüentes deficiências observadas em alguns dos trabalhos já publicados. No capítulo 2, fazemos uma análise de alguns livros paradidáticos de ciências apontando algumas deficiências percebidas por nós. As críticas são fundamentadas nos Critérios de avaliação dos livros didáticos em trabalho, elaborados pela Secretaria de Ensino Fundamental do Ministério da Educação e do Desporto, no Programa Nacional do Livro Didático (BRASIL, 1998), os quais encontram-se anexados no capítulo em questão.

A nossa proposta para os livros paradidáticos de física estão descritas integralmente no capítulo 3 , ressaltando a metodologia utilizada.

No capítulo 4 são colocadas as descrições dos três livros que nós propusemos a elaborar, bem como, o conteúdo explorado em suas páginas.

No capítulo 5 mostramos uma avaliação qualitativa do material feita com alguns adultos, adolescentes e crianças os quais demonstraram-se favoráveis mediante a leitura dos livros. 
Introdução - 3

E por fim, colocamos os três livros em anexos. 


\section{2- O TRABALHO}

\section{1- Objetivo do Trabalho}

O presente trabalho pretende apresentar três livros paradidáticos que ressaltam alguns dos fascínios da física para leitores com idade a partir de 12 anos.

Nosso objetivo consiste em propor livros cujo conteúdo seja colocado de forma que o leitor reconstrua verdades que na maioria das vezes são apenas transmitidas (PIAGET, 1984). Para tanto, o assunto abordado em cada livro é apresentado a partir de problemas do dia a dia, com os quais são envolvidos alguns conceitos científicos.

Outro aspecto que nos objetivou foi o desenvolvimento de livros que pudessem ser compreendidos sem a necessidade do acompanhamento de um profissional da área. Por essa razão, os experimentos contidos na obra são relativamente simples e foram rigorosamente testados. Procuramos também, fornecer explicações dos conceitos físicos envolvidos nas atividades sugeridas, com o intuito de estimular o leitor. 
Tivemos, como principal preocupação, desenvolver um texto estimulador da compreensão, e não somente da memorização. Além disso, privilegiamos sempre que possível, a conexão entre ciência e tecnologia atual.

Considerando todos os aspectos citados acima, esperamos que a leitura dos livros de física em questão possam desmistificar essa ciência tão mal aceita pelos estudantes.

\section{2 - Justificativa do Trabalho}

Os livros denominados paradidáticos, os quais são definidos por FERREIRA (1993) como "Qualquer material utilizado na complementação do ensino", têm tido uma grande aceitação no mercado, sendo muito usado por alunos e professores. Isso é tão verdade que o Governo do Estado de São Paulo, por meio da Secretaria de Estado da Educação-SEE, lançou o programa LEIA MAIS, que "prevê a distribuição de quase três milhões de livros não-didáticos a escolas que oferecem o ensino médio" (SÃO PAULO, 2002).

Porém, o mercado mostra grande carência de livros paradidáticos de física, que em nossa opinião, possuem diversas deficiências.

A título de ilustração, vamos citar alguns desses livros e as respectivas falhas que neles detectamos. É importante salientar que as críticas são feitas com cunho construtivo, visando a melhoria dos mesmos e que não temos a pretensão de fazer uma análise detalhada destes textos. 
No livro Como a Ciência funciona, nome original How Science Works, editora Globo, 1994, encontramos deficiências referentes à:

1. Experimentos que proporcionam resultados que não condizem com o que se propõe.

O livro sugeriu a construção de uma pilha, com uma tira de zinco e tubo de cobre, imersas em vinagre e ligadas através de dois cabos com jacaré a um led. Conforme a descrição do experimento, o led bilhará, fato esse irreal, porque um led vermelho, necessita de uma tensão minima que varia entre $1,5 \mathrm{~V}$ a $2,2 \mathrm{~V}$ para brilhar, sendo que a diferença de potencial estabelecida entre esses metais é 1,1V (BRADY, 1986, p.42).

Ao ser sugerida a construção de um motor elétrico, a apresentação do procedimento é demasiadamente confusa, sendo quase impossivel à reprodução do experimento.

2. Problemas com ilustração e erro conceitual.

No livro é apresentado um esquema de pilha, com uma tira de zinco e um tubo de cobre mergulhados em meio ácido, representando a placa de cobre carregada negativamente e placa de zinco positivamente, sendo que o correto (BRADY, 1986, p.610) é justamente o inverso.

No livro Coleção Jovem Cientista - Eletricidade, nome original My science book of electricity, editora Globo, 1996, as deficiências encontradas se referem principalmente a:

1. Experimentos que proporcionam resultados que não condizem com o que se propõe. 
O livro propõe experiências que abrangem efeitos eletrostáticos. No entanto, não é mencionado que a umidade do ar influencia nos resultados e assim, dependendo da região e época que o leitor se propuser a reproduzir essas experiências, não obterá o resultado desejado.

Uma outra deficiência foi observada em uma experiência, denominada "Estalidos e faíscas", destinada a mostrar a detecção de ondas eletromagnéticas e faíscas. Tal experimento possui falhas com respeito à omissão de detalhes no procedimento da experiência. Além disso, as explicações para os resultados são insuficientes para a compreensão dos fenômenos pelos leitores.

O livro Experiências Elétricas: Simples e Seguras, nome original Safe and Simple Electrical Experiments, editora Ediouro, 1981 nos chamou a atenção por ter sido distribuído pelo Governo do Estado de São Paulo nas escolas públicas.

Sua principal deficiência foi constatada nas experiências que envolvem efeitos eletrostáticos, por causa da influencia da umidade do ar, conforme já discutimos. Esse fato pode ser explicado por meio da observação da ficha técnica do livro, comprovando que o mesmo é traduzido. Infelizmente, o leitor que não tem conhecimento prévio sobre o tema se desanimará ao realizar a experiência proposta sem conseguir reproduzi-la, desinteressando-se pelo assunto.

Como se pode observar, a maioria dos problemas encontrados nos referidos livros, deve-se ao caráter da não adaptação da traclução à nossa realidade. E a falta de revisão, pois não é aconselhável traduzir um livro que apresenta erros conceituais, sem corrigi-los. 
O livro, Fisica mais que divertida, editora UFMG, 2000, propõe experimentos, com o objetivo de que o leitor vivencie os fenômenos, sem se preocupar com teorias e, apenas verifique que eles existem. Mas, podemos fazer algumas observações, no intuito de colaborar para a melhoria da aprendizagem. Dentre elas, notamos que a falta dos conceitos físicos envolvidos em alguns experimentos, não produz no leitor a satisfação, que sempre lhes é peculiar ao compreender a explicação que os físicos oferecem para justificar o resultado das experiências.

Cabe observar que, alguns problemas complicados, tanto técnicos como teóricos, são colocados de forma muito simplificada, sem fazer previamente uma introdução sobre prováveis problemas e o que se quer descobrir, ignorando pois o conhecimento prévio que o experimentador deve possuir para melhor entender o objetivo da atividade que realiza.

Outro aspecto relevante a ser considerado é a falta de medidas dos componentes utilizados nas experiências, pois gera problemas no início da montagem. O jovem, provavelmente imaturo que irá realizár essas experiências, certamente encontrará serias dificuldades para chegar nas dimensões do equipamento que deverá utilizar.

Além disso, o índice do livro, tal como se apresenta não mostra realmente o que se quer explorar, qual parte da física se quer atingir, por exemplo, "Faça o seu spray".

O livro, Eletricidade: história e aplicações, Editora Moderna, 1991, propõe mostrar a história da eletricidade, a fim de expor ao leitor o progresso científico. Consideramos esse objetivo de extrema valia para o aprendizado do ser humano.

O livro em questão possui um vocabulário simples, ilustrações didáticas e ausência de fórmulas, qualidades essas que o tornam viável tanto para alunos do 
ensino fundamental como para o ensino médio. A interdisciplinaridade explorada nas áreas de biologia e geografia, no texto, é outro fatcr positivo encontrado na obra.

Dentre as poucas deficiências encontradas, citamos o fato de não alertarem para possiveis danos à integridade física da pessoa na realização das experiências.

As críticas citadas anteriormente foram fundamentadas nos critérios utilizados pelo Programa Nacional do Livro Didático (PNLD), criadı pelo Ministério da Educação e do Desporto (MEC), (BRASIL, 1998), que teve como objetivo a melhoria da qualidade dos livros de $5^{a}$ a $8^{a}$ séries. Esses critérios foram recomendados para a análise desses livros e ainda não foram publicados critérios para a análise de livros paradidáticos.

Para efeito de recomendação dos textos nas escolas brasileiras os critérios são considerados como eliminatórios e classificatórios. Os primeiros se referem à presença nos livros, de erros conceituais e metodologia inadequada ao nível cognitivo do aluno, além de ausência de contribuições visando o desenvolvimento de cidadania e alertas para os riscos à integridade física dos estudantes na realização de determinadas experiências sugeridas.

Seguem-se os critérios classificados como classificatórios:

- Adequação dos conteúdos

"É essencial que o conteúdo desenvolvido seja pertinente, socialmente relevante e acessivel ao aluno, considerando-se a faixa etária a que se destina" (BRASIL, 1998). 
- Atividades propostas

"Atividades instigantes, problemas realistas, projetos de investigação, atividades em grupo, enquetes, dramatizações, debates, exposição de trabalhos que incentivem a troca de idéias, a tolerância e a valorização dos saberes do alunado" (BRASIL, 1998).

- Integração entre temas nos capítulos.

"O livro didático deve ser concebido para a clientela a que se destina, a qual deve compreendê-lo em sua totalidade, percebendo a ligação existente entre suas partes" (BRASIL, 1998).

- Valorização da experiência de vida do aluno

"Um texto didático deve incentivar a exposição de idéias dentro do universo cultural, ainda que restrito, ao qual se aplicam, mesmo que não estejam exatamente de acordo com o conhecimento cientifico sistematizado, que depende pouco de contexto" (BRASIL, 1998).

- Aspectos visuais

"Especial cuidado deve ser tomado com a realidade de formas e tamanhos, evitando-se distorções quanto à realidade representada e, quando possivel, com explicitação de escala" (BRASIL, 1998).

- Manual do professor

O manual do professor deverá "conter diversas sugestões de atividades extraclasse, detalhamento de atividades práticas, materiais necessários, além de uma 
rigorosa exposição de cuidados a serem adotados e riscos potenciais envolvidos nas atividades" (BRASIL, 1998).

Considerando-se assim todos os aspectos colocados nesse capítulo referentes às deficiências dos livros avaliados e os critérios que devem ser seguidos em sua avaliação, concluímos que há uma enorme carência de materiais voltados para nossa realidade, que apresentam rigorosamente os conceitos e as atividades que propõem. Dessa forma, com a intenção de contribuir para a diminuição desta lacuna no ensino brasileiro de física, estamos propondo três livros paradidáticos de física, os quais foram elaborados tendo em vista alguns dos critérios definidos pelo Ministério da Educação e do Desporto - MEC, citados acima. Digo alguns, porque a obra apresentada sendo de livros paradidáticos não poderia atender a todos os critérios estabelecidos para a avaliação de livros didáticos. 


\section{3- A PROPOSTA DOS LIVROS}

Partindo do princípio de que a sensação de descoberta é um componente extremamente importante no que se refere ao processo de aprendizagem, pois estimula o interesse das pessoas pelo assunto que estão aprendendo, estamos propondo livros paradidáticos cuja estruturação privilegia questionamentos para reflexão dos conceitos envolvidos nos fenômenos físicos.

Vejamos o que diz NETTO (1974, p.107), "De modo geral, os alunos têm interesse em procurar, por si mesmos, respostas a perguntas que Ihes sejam formuladas. Isto ocorre já nos primeiros anos de escola. Portanto, dar ao aluno a resposta pronta, se outro mal não tivesse, pelo menos representaria a privação de uma tendência natural do intelecto: a descoberta".

A proposta dos livros, que será apresentada, foi decorrente de uma incessante pesquisa. A primórdio, escrevemos parte de um livro que possuia semelhanças com o livro didático, no entanto, para tal, necessitaríamos de um tempo maior do que dispúnhamos, além de percebermos que o material não preenchia nossas expectativas, pois pretendíamos compor uma obra que mostrasse conceitos físicos por meio de experimentos. Após observarmos tal fato, optamos por um livro paradidático. Partindo dessa idéia, elaboramos um outro livro onde os experimentos obedeciam a 
uma ordem cronológica e anexando a cada um a explicação dos conceitos envolvidos nos fenômenos em estudo. Todavia, essa forma também não preenchia nossa expectativa, pois os fatos históricos impunham uma seqüência para a colocação dos experimentos. Diante disso, escrevemos novamente um outro livro inserindo experimentos e dados históricos em uma narrativa, pois desse modo, poderiamos explorar um determinado tópico sem o compromisso de uma cronologia e, acima de tudo, possibilitando uma maior liberdade para trabalhar a história juntamente com os experimentos. Tal estruturação está descrita a seguir.

O conteúdo dos livros é apresentado por meio de uma narrativa ficcional, na voz de quatro adolescentes: Pedro, um garoto de 16 anos, persistente e curioso; Marcelo, 15 anos, que tem verdadeiro fascínio por computador; Patrícia, 15 anos, é uma adolescente fascinada por livros; e Tales, 12 anos, irmão de Marcelo, um garoto muito esperto e curioso.

A narrativa composta por esses quatro adolescentes pode ser assim resumida: os jovens são incentivados a desvendar os mistérios da física por um site, denominado LUIZ ANTONIO RESPONDE. Esse site, por sua vez, conduzirá toda a trama, aguçando a curiosidade dos garotos com atividades simples e de baixo custo. $\mathrm{Na}$ busca para o entendimento dessas atividades, eles descobrirão fatos históricos relacionados aos tópicos abordados, compreenderão alguns fenômenos que estão presentes no cotidiano, aprenderão a procurar informações, bem como todos os conceitos físicos envolvidos nas experiências.

É importante ressaltar que os livros formam uma seqüência: "O enigma de Tales de Mileto", "As aventuras de Pedro" e "Blackout", embora possam ser lidos independentemente. 
Outro aspecto relevante a ser considerado é a real existência do site, que não é indispensável para o entendimento do conteúdo dos livros. De maneira geral, o objetivo da inclusão do site é mostrar a viabilidade de tal procedimento. Para trabalhos futuros pretendemos implementá-lo realmente, com o intuito de proporcionar ao leitor outra fonte de informações.

$\mathrm{Na}$ elaboração do conteúdo dessa obra, fomos cautelosos quanto aos experimentos propostos, os quais foram rigorosamente testados, evitando dessa maneira, a frustração do leitor diante do fracasso da experiência. Alertamos, entretanto, que o leitor precisará trabalhar com afinco e prazer, para obter o sucesso necessário. O livro também incentiva a construção de experimentos, pois acreditamos que essa prática seja um estimulo à criatividade.

Propusemos explicações para os experimentos, com palavras de uso cotidiano em detrimento da utilização de termos técnicos, possibilitando uma melhor compreensão. De forma a privilegiar os conceitos físicos, utilizamos fórmulas somente quando necessário, mas quando isso foi feito, quase sempre, essas fórmulas se apresentaram como produto final do desenvolvimento científico que foram vinculadas às experiências executadas pelos adolescentes. Desse modo, tentamos afastar o tradicional hábito de decorar fórmulas sem a compreensão do seu significado. Além disso, HARTWING (1988, p.214) afirma que "independente do nivel de raciocínio proporcional, os alunos preferem não utilizar fórmulas, então, estas deveriam ser utilizadas apenas em situações especiais, isto é, quando o assunto não é realmente passivel de tal abordagem".

A fim de estimular ainda mais o leitor, é valorizado seu conhecimento prévio. No decorrer da narrativa provocamos situações envolvendo trocas de opiniões e debates. 
Procuramos também propor circunstâncias que mastrem formas de obter informações, sempre relacionando os tópicos abordados.

Quanto à editoração, utilizamos "caixas" com o objetivo de facilitar a leitura. Assim estruturado o texto, aqueles leitores que possuem o conhecimento do tópico podem ater-se apenas aos procedimentos dos experimentos, os quais foram ilustrados com fotos para uma melhor compreensão. Todas as ilustrações foram introduzidas visando auxiliar a compreensão dos conceitos físicos, esperando-se que suas formas e tamanhos sejam adequadas ao objetivo a que foram propostas.

Cabe observar, ainda, que inserimos aplicações tecnológicas que são comumente utilizados no dia a dia do leitor, como por exemplo, a fotocopiadora Xerox, com o intuito de mostrar que a física estudada na escola, encontra-se no mundo que o cerca.

Por fim, colocamos uma página com comentários e cuidados acerca dos materiais utilizados nas experiências, assim como eventuais substituições dos mesmos quando necessário.

\section{1- Metodologia e aprendizagem}

O presente trabalho enfoca, a criação de obras que privilegie situações padrões, como o cotidiano de adolescentes, que vão à escola, estabelecendo assim, uma aproximação entre o leitor e as personagens.

Considerando-se que a leitura seja uma ferramenta que subsidia o estudo de qualquer área do conhecimento, apresentamos urn material que mostre os conceitos 
físicos por meio de uma narrativa. Acreditamos que deste modo o leitor poderá desenvolver o hábito de leitura e, conseqüentemente o entendimento dos fenômenos físicos.

Uma outra preocupação foi à inserção de dados históricos, com o objetivo de mostrar ao leitor que as teorias cientificas estão em constante desenvolvimento e, evitando assim, a concepção que seja considerada como dogmas, isto é, como verdades absolutas, imutáveis e irrefutáveis.

Todavia, o ponto mais alto da nossa estruturação metodológica baseia-se na procura das personagens pelo conhecimento. Isso é proposto da seguinte forma: os adolescentes impulsionados por um site, estão sempre procurando soluções para o entendimento dos seus problemas e, a cada dúvida esclarecida, surgem várias outras, tornando incessante essa busca. De maneira geral, essa metodologia possui semelhanças com a concepção sobre a Psicologia Genética proposta por PIAGET (1994).

Embora, erroneamente, muitos pensem que Jean Piaget tenha elaborado um método pedagógico, isso não ocorreu, pois o método piagetiano é apenas uma abordagem de pesquisa.

Cabe observar ainda, que Piaget formou-se em Biologia; no entanto, dedicou-se ao estudo da filosofia e em particular a teoria do conhecimento. Desde jovem ele esteve preocupado com as questões polêmicas de sua época, o que justifica a grande atenção dada por ele à educação.

Com certeza, seu trabalho se destacou no contexto da educação escolar, ou melhor, da pedagogia. Suas idéias são fundamentadas no seguinte pensamento: "o conhecimento só é possível quando o Sujeito, aquele que irá conhecer, e o Objeto, aquilo que será conhecido, relacionam-se de uma determinada maneira: o Sujeito age 
sobre o Objeto" CUNHA (2000). Sendo esse desequilíbrio o responsável pela geração do conhecimento.

Tomemos como exemplo o ambiente escolar. Para que haja aquisição de conhecimento por parte do aluno é necessário que o professor crie um desequilibrio entre o conteúdo a ser ensinado e o aluno que irá aprendê-lo, de forma a aguçar o interesse por um equilibrio, entre Sujeito e Objeto.

Em suma, o conhecimento ocorre quando o Sujeito atua para vencer o desequilibrio existente entre ele e o objeto.

Essas conclusões foram obtidas com o estudo do progresso das categorias de conhecimento no decorrer da vida de uma pessoa. Segundo PIAGET (1994, p.99) "toda pesquisa em psicologia científica deve partir do desenvolvimento e que a formação dos mecanismos mentais na criança é o que melhor explica a natureza e o funcionamento desses mecanismos no adulto". Daí surge o termo genético, o qual refere-se à abordagem de estudo do objeto desde sua origem até seu estágio mais adiantado, fazendo um acompanhamento das sucessivas etapas desse percurso.

Diante disso, as pesquisas de Piaget o levaram a dividir em quatro estágios pelos quais passam um indivíduo, mas é importante observar que as idades são meramente indicativas, em linhas gerais se observa a seguinte seqüência:

- Primeiro estágio, também chamado sensório-motor, que abrange crianças de 0 aos 2 anos de idade e, distingui-se pelo desenvolvimento das ações e dos reflexos do aparelho motor. Nesse periodo a estrutura da representação mental é constituido por ações, visto que, não há figuração mental.

- Segundo estágio, por volta dos 2 aos 7 anos, a criança torna-se mais adaptada no meio em que vive. Essa fase é evidenciada na linguagem, pois as 
expressões são usadas de forma socialmente convencionada tornando a comunicação individual em grupo social.

- Terceiro estágio, incorpora crianças de 7 aos 12 anos, aproximadamente, sendo denominada de operatório concreto. Nessa fase, a criança torna-se apta a desenvolver mentalmente situações inversas, isto é, do ponto final ao ponto inicial. Entretanto, essas operações ocorrem apenas com objetos ou situações previamente conhecidas.

- Quarto estágio, conhecido como operatório formal, engloba indivíduos de aproximadamente 12 anos até a idade adulta. Nesse último período ocorre a transformação do pensamento concreto no pensamento abstrato onde "as operações assumem caráter proposicional, permitindo ao indivíduo raciocinar de maneira totalmente abstrata e elaborar mentalmente hipóteses, ou seja, possibilidades sobre eventos ainda não ocorridos. Integra suas possibilidades de pensamento até mesmo aquilo que ele não acredita que possa existir" (CUNHA, 2000, p.91). Nessa fase o desenvolvimento cognitivo atinge o ponto mais alto, pois agora $o$ individuo possui capacidade de partir de possibilidades para, a partir delas, raciocinar ou experimentar. O indivíduo atinge maturidade intelectual, isto é, seus trabalhos mentais alcançaram o nivel máximo de desenvolvimento e, através da prática tornar-se-ão mais eficientes e mais coerentes.

Nesse quadro, o material proposto nessa dissertação objetivou o público do terceiro e quarto estágio. 


\section{4 -DESCRIÇÃO DOS LIVROS}

Os livros descritos nesse capitulo encontram-se nos anexos.

\section{1- O Enigma de Tales de Mileto}

O livro que descreveremos é intitulado "O Enigma de Tales de Mileto" e tem como tema a Eletrostática.

O enredo principia no encontro das personagens em uma lanchonete e, em determinado momento da conversa, Tales, o mais novo do grupo, conta que na noite anterior estava navegando na internet e por acaso encontrou a biografia de um filósofo matemático chamado Tales de Mileto. Devido à identificação com seu nome, Tales pesquisou o assunto e, para sua surpresa, encontrou um fenômeno intrigante; o filósofo havia atritado um pedaço de âmbar com pele de animal, o qual adquiriu a propriedade de atrair objetos leves. Entretanto, a história limitava a demonstração dos fatos, sem qualquer explicação.

Os garotos, interessados naquela história, resolvem verificar sua veracidade. Então atritam canudos plásticos com papel higiênico e comprovam que realmente os 
canudos atraiam pequenos pedaços de papel higiênico, mas eles não conseguem explicar a ação de uma força sem contato. Como solução procuram um site de física, chamado LUIZ ANTONIO RESPONDE que esclarece dúvidas concernentes aos conceitos de física. A fim de estimular ainda mais os garotos o site propõe um outro experimento, com resultado inverso, ou seja, força de repulsão, supondo que assim eles seriam capazes de responder aquela dúvida.

Contudo mais dúvidas surgiram. Eles não entendiam o que causava aquela força que ora atraia e ora repelia os objetos, e retornaram ao site. Luiz Antônio vendo ser impossivel os garotos entenderem sozinhos os conceitos de física envolvidos naquelas atividades, fornece-Ihes uma breve explicação.

A partir daí, os garotos começam a se questionar sobre os fenômenos eletrostáticos e surgem dúvidas quanto à detecção das cargas. Com o conhecimento em física que possuíam, não conseguiram visualizar esclarecimentos para os fatos. Recorrem novamente ao site que os ensina a construir um pêndulo eletrostático. Muito empolgados com o experimento, procuram informações em livros e descobrem o procedimento da construção de um eletroscópio de folhas. Durante a discussão dos conceitos envolvidos no experimento, eles se questionam sobre a eletrização e, após uma consulta ao site aprendem, a eletrizar um objeto por indução, a partir de uma atividade. Em meio a essas discussões os garotos consultando o site, os livros e um professor de física, lentamente vão desvendando o mundo da eletrostática.

Assim apresentado, ao fazer a leitura do livro, o leitor, obterá conhecimento acerca de: processos de eletrização; lei da conservação da carga elétrica; quantização da carga elétrica; força de Coulomb; conceito de campo de força; efeito do poder das pontas; blindagem eletrostática (Lei de Gauss), assim como, a inserção desses tópicos em contexto histórico. 
Por fim, inserimos o princípio de funcionamento da fotocopiadora Xerox. A justificativa dessa escolha centra-se na sua atualidade e, acima de tudo, o fato dela estabelecer uma ligação entre conceitos científicos e sua aplicação tecnológica.

Cabe observar ainda, que no transcorrer da narrativa, as personagens vão se caracterizando. Pedro, por ser o mais velho e já possuir muitas informações de física, acaba se sobressaindo perante os colegas e, com isso, seu interesse aumenta cada vez mais. Patrícia, no decorrer da história descobre um verdadeiro fascínio pela história da ciência e começa a desenvolver a habilidade de procurar informações na biblioteca. Marcelo se mantém preso ao grupo porque as reuniões são feitas em sua casa que se tornou o local para os garotos construirem e discutirem os experimentos. Acaba descobrindo que possui uma enorme afinidade por computador. Tales, mais novo em relação aos demais colegas, não se intimida com o fato e passa a questionar tudo que não entende.

A narrativa termina com última pergunta deixada por Pedro "Existe uma relação entre os conceitos aprendidos nas experiências e a eletricidade responsável por manter as lâmpadas acesas".

\section{2 - As Aventuras de Pedro}

No livro "As Aventuras de Pedro", exploramos o tema eletricidade dinâmica, por meio de uma a narrativa, a qual pode ser assim resumida: Pedro relata aos colegas histórias interessantes obtidas em um museu de ciências em São Carlos, o "CDCC" (Centro de Divulgação Científica e Cultural). Em meio às várias histórias, ele relembrou 
a pergunta feita na ultima vez que se encontraram, mas seus amigos já não se lembravam. Pedro então os recorda e propõe um experimento, no qual é pedido para acenderem uma lâmpada fluorescente com canudos eletrizados. Os garotos ficam impressionados com o resultado, e surgem vários questionamentos, como o que haveria dentro da lâmpada. Pedro responde a todas perguntas com bastante clareza. Depois de várias discussões, concordam que não é nada prático acender uma lâmpada com canudos eletrizados, e Marcelo propõe que os canudos sejam substituídos por uma pilha. Para surpresa de todos, Pedro entrega o procedimento que ensina como construir pilhas.

Primeiramente eles constroem alguns materiais que serão reutilizados em todas as atividades e em seguida montam uma pilha utilizando como solução o vinagre. Para comprovar que a pilha realmente funciona, eles utilizam um led. A partir daí, são gerados novos questionamentos e discussões sobre o funcionamento da pilha e do led, sendo que algumas perguntas serão respondidas por Pedro e outras pelo site LUIZ ANTONIO RESPONDE. Julgamos ser viável a utilização desse experimento, em virtude de tratar da questão da interdisciplinaridade, pois mostra o elo entre a química e a física. Além disso, no transcorrer da narrativa os adolescentes se questionam sobre os fenômenos naturais e, na busca de tentar desvendar o mundo que os cercam eles se contagiarão pela eletricidade.

Mediante a leitura desse livro é possivel a compreensão dos conceitos de diferença de potencial, de resistência elétrica, de corrente elétrica, da lei de Ohm e de resistores não ôhmicos, tomando como exemplo resistores dependentes da temperatura "NTC" e da luz "LDR", sendo todos esses conceitos exemplificados com experiências. No meio da narrativa são inseridos dados históricos pelas personagens. 
Considerando que é importante que o leitor perceba o elo entre a evolução científica e tecnologia, finalizamos a obra com circuitos que utilizam dispositivos cuja condução elétrica é controlada externamente, tais como: LDR, NTC e transistor.

\section{3-Blackout}

O livro "Blackout" tem como tema o eletromagnetismo. A narrativa tem inicio, com a interrupção da energia elétrica no dia do aniversário de Tales. Impressionado com o susto por achar que sua festa não aconteceria, o garoto em meio aos colegas conta o ocorrido. Dai surge uma discussão sobre a geração de energia elétrica, que será esclarecida por Patricia, com um trabalho feito por ela, acerca desse assunto.

Após o entendimento sobre as formas de geração de energia elétrica, surge a dúvida sobre o funcionamento do gerador. Como solução para o problema recorrem ao site LUIZ ANTONIO RESPONDE, que propõe a construção de uma pilha, com o objetivo de mostrar o processo de transformação de energia e, uma das mais importantes leis da ciência a lei da conservação de energia. Contudo, a experiência não foi suficiente para o entendimento do funcionamento do gerador. $E$, na busca incessante pelo entendimento dessa máquina, os garotos aprenderão por meio de experimentos o que são: processos de transformação da energia; lei da conservação da energia; propriedades dos imãs; não existência de monopolo magnético; linhas de campo magnético; indução magnética (lei de Faraday); principio de funcionamento da bússola; desmagnetização; corrente elétrica gera campo magnético; 
É importante relembrar que todos esses conceitos são acompanhados pela introdução de dados históricos no decorrer da narrativa pelas personagens.

A narrativa termina com uma viagem à Estação Ciência, onde eles puderam aprender como funciona o motor elétrico e algumas aplicações tecnológicas do eletromagnetismo tais como o principio de funcionamento do gravador de fitas e do cartão magnético. 


\section{5- CONCLUSÃO}

A leitura dos livros paradidáticos de física: "O enigma de Tales de Mileto", "As aventuras de Pedro" e "Blackout", constituem em uma atividade complementar para a aprendizagem de eletricidade, propiciando uma visão mais ampla e contextualizada dos tópicos abordados nos mesmos.

A fim de comprovar a viabilidade da metodologia utilizada no material a qual se baseia nas idéias de Piaget, (que considera o conhecimento gerado através da ação do indivíduo sobre o que se pretende conhecer) e, nos Parâmetros Curriculares Nacionais (PCN's), fizemos pesquisas de campo com adolescentes, crianças, professores da rede pública e alunos do quarto ano do curso de Licenciatura em Ciências Exatas do Instituto de Física de São Carlos da Universidade de São Paulo.

Com relação aos adolescentes, propusemos um curso na Escola Estadual Juliano Neto, com duração de três dias, para vinte e quatro alunos, sendo oito alunos da terceira série do ensino fundamental, oito da primeira e oito da terceira série do ensino médio. As atividades constituíram na leitura e realização dos experimentos, sem haver intervenções por nossa parte, porque o objetivo era avaliar a interação do aluno com o material. 
Após a leitura, eles se mostraram verbalmente motivados pelas experiências e pelas aplicações tecnológicas, comentando que seus professores poderiam dar aula com o auxilio de experimentos, pois facilitava a compreensão.

As crianças também se mostraram interessadas nos experimentos, fato esse que julgamos de grande relevância, pois mesmo não compreendendo os fenômenos observados, elas estão entrando em contato com a física e quando esse tópico for ministrado nas escolas, serão capazes de fazer uma correlação, propiciando assim, uma eficaz aprendizagem.

Os professores da rede pública tiveram contato com o material através de um curso de extensão universitária denominado "Ensino contemporâneo de física à luz dos parâmetros curriculares nacionais (PCN's)". A atividade se deu através da leitura e execução das experiências pelos próprios professores. Eles se mostraram receptivos ao material, alegando verbalmente que o mesmo auxilia na preparação da aula, visto que, seu tempo disponivel para procurar experiências é escasso.

Os alunos do curso de Licenciatura leram e testaram todas as experiências do material, na disciplina Prática de Ensino de Física. Seus comentários forneceram dados para uma apreciação positiva do trabalho.

Esse material também foi apresentado no XIV Simpósio Nacional de Ensino de Física, onde obteve grande aceitabilidade por parte de pesquisadores e professores do segundo grau. Além disso, submetemos o material para ser criticados por profissionais da área, os quais mostraram-se favoráveis.

Cabe observar que, grande parte das sugestões e observações, com relação à editoração e apresentação do conteúdo, feitas nas avaliações citadas acima, forneceu informações pertinentes para o aperfeiçoamento do trabalho. 
No futuro pretendemos criar colaborações com pesquisadores da área de ensino de Física e especialistas em educação, para que possam fazer análises quantitativas do nosso trabalho, capazes de nos fornecer dados fidedignos e sistematizados de sua avaliação. 


\section{6 - REFERÊNCIAS BIBLIOGRÁFICAS}

Adolescente sabe o que quer de um paradidático. Revista Submarino. Disponivel em: <http:/www.revistasubmarino.com.br/submarino/calandra.nsf/0/9C68FDEE2622A57503 256>. Acesso em: 30 nov. 2001.

ARDLEY, J.N. Coleção Jovem Cientista Eletricidade. Rio de Janeiro: Globo, 1996.

BENJAMIN, A. A. Análise do uso de um texto paradidático sobre energia e meio ambiente. 2000. 184p. Tese (Doutorado) - Faculdade de Ciências, Universidade Estadual Paulista.

BRADY, J.E.; HUMISTON, G.E. Química geral. 2.ed. Rio de Janeiro: Livros Técnicos e Científicos Editora Ltda., 1986. v.2. 
BRASIL. Ministério da Educação e do Desporto. Secretaria de Educação Fundamental. Guia dos Livros Didáticos $5^{\mathrm{a}}$ a $8^{\mathrm{a}}$ Séries - Plano Nacional do Livro Didático - 1999. Brasilia, 1998, p.13-17, 325-335.

CUNHA, M.V. Psicologia da Educação. Rio de Janeiro: DP\&A, 2000.

DE FIORI, OTTAVIANO. As políticas do livro. Disponivel em: <www.minc.gov.br/textos/olhar/politicaslivro.htm>. Acesso em: 30 nov. 2001.

FERRARO, N. G. Eletricidade: história e aplicações. São Paulo: Moderna, 1991.

FERREIRA, A. B. H. Minidicionário da Língua Portuguesa. 3.ed. Rio de Janeiro: Nova Fronteira, 1993.

GRAF, R. F. Experiências Elétricas: Simples e Seguras. Trad. de Fernando B. Ximenes. Rio de Janeiro: Ediouro, 1981.

HANN, J. Como a Ciencia Funciona. São Paulo, Globo, 1994.

HARTWING, D.R. Uma estrutura para as operações fatoriais e a tendência na utilização de fórmulas matemáticas: um estudo exploratório. 1998. 256p. Tese (Doutorado) - Faculdade de Educação, Universidade de São Paulo.

LOBATO, M. Emília no país da gramática. 6.ed. São Paulo: Editora Brasiliense, 1975. 
LIMA, M.C.B.; ALVES, L.A.; LEDO, M.R.A.G. Contando história... Apresentando a Física. Caderno Catarinense de Ensino de Física, v.13, n.2, p. 89-107, ago. 1996.

NETTO, S. P.; ROSAMILHA, N.; DIB, C. Z. O livro na Educação. Rio de Janeiro: Primor/INL, 1974.

MATTHEWS, M. Construtivismo e o ensino de ciências: uma avaliação. Caderno Catarinense de Ensino de Física, v.17, n. 3, p. 270-294, dez.2000.

PAIVA, E. F. Texto e imagem no paradidático de história. Disponível em: $<\mathrm{http}: / / \mathrm{www}$.editoradimensao.com.br/revistas/revista36_trecho.htm>. Acesso em: 30 nov. 2001.

PIAGET, J. Para onde vai a educação? Trad. de Ivete Braga. 8.ed. Rio de Janeiro: José Olympio, 1984.

PIAGET, J. Seis estudos de psicologia. Trad. de M.A.M. D'Amorim e P.S.L. Silva. 20.ed. Rio de Janeiro: Forense Universitária, 1994

PENTEADO, W. M. A., org. Psicologia e ensino. São Paulo: Papelivros, 1986.

PIMENTEL, J. R. Livros Didáticos de Ciências: A Fisica e Alguns Problemas. Caderno Catarinense de Ensino de Física, v.15, n. 3, p. 308-318, dez. 1998. 
SÃO PAULO. Secretaria de Educação do Estado de São Paulo. Programa Leia Mais impulsiona mercado editorial brasileiro. Disponivel em: <http://uww.educação.sp.gov.br>. Acesso em: 22 fev. 2002.

SERRA, E. D. Literatura e literatura infantil. Disponivel em: <http://www.minc.gov.br/textos/olhar/literaturainfantil.htm>. Acesso em: 30 nov. 2001.

SILVA, F. P. Paradidático clareia conceitos. Folha de S. Paulo, São Paulo, $1^{0}$ nov. 2001, Fovest, p.1.

VALADARES, E.C. Física mais que divertida. Belo Horizonte: UFMG, 2000. 


\section{7- REFERÊNCIAS CONSULTADAS}

ARDLEY, N. Coleção Jovem Cientista Eletricidade. Rio de Janeiro: Globo, 1996.

BASSALO, J.M.F. Crônicas da Física. 1.ed. Belérn: GEU, 1987.

BLACKWOOD, O.H.; HERRON, W.B.; KELLY, W.C. Física na Escola Secundária. 2.ed. s.I., MEC, 1962.

BLOOMFIELD, L.A. How things work: the physics of everyday life. New York: John Wile \& Sons, Inc., 1996.

BRADY, J.E.; HUMISTON, G.E. Química geral. 2.ed. Rio de Janeiro: Livros Técnicos e Científicos Editora Ltda., 1986. v.2.

CAVALCANTI, J. Semicondutores: análise da estrutura e princípio de funcionamento. São Paulo: Editora Fittipaldi Ltda., 1988. 
Constituição do LDR e suas aplicações. Disponível em: <http://www.hpeletronica.hpg.ig.com.br>. Acesso em: 30 nov, 2001.

CRUZ, G. K. Uma Nova Visão para Conduzir as Atividades Iniciais do Laboratório de Eletricidade. Revista Brasileira de Ensino de Física, v.19, n. 2, jun. 1997.

CUTNELL, J.D. JOHNSON, K.W. Physics. 2.ed. New York: John Wiley \& Sons, Inc., 1992.

DUARTE, M. O livro das invenções. São Paulo: Companhia das Letras, 1997.

EISBERG, R. M.; LAWRENCE, S. L. Física: Fundamentos e aplicações. São Paulo: McGraw-Hill do Brasil, 1982.

EISBERG, R.; RESNICK, R. Física Quântica. Rio de Janeiro: Campus, 1979.

Enciclopédia de Ciência e Técnica. Como Funciona. São Paulo: Abril S.A. Cultural e Industrial, 1975. v.3.

Energia Nuclear: custos de uma alternativa. Revista ComCiencia. Disponível em: $<\mathrm{http}: / / \mathrm{www} . c o m c i e n c i a . b r / r e p o r t a g e n s / n u c l e a r / n u c l e a r 13 . h t m>$. Acesso em: 30 nov. 2001. 
FARIAS, A. J. O. Existem Dificuldades dos Alunos na Interpretação da Interação Carga-Campo? Revista Brasileira de Ensino de Física, v.21, n. 3, p. 389-396, set. 1999.

FERREIRA, N. Actividades em Electrostática. Gazeta de Física, v.12, n.1, p. 27-34, jan.1989.

FEYNMAN, R.P.; LEIGHTON, R.B.; SANDS.M. The Feynman lectures on physics: mainly electromagnetism and matter. 3.ed. Massachussets: Addison-Wesley, 1965.

GASPAR, A. Experiências de Ciências para o $1^{\circ}$ Grau. São Paulo: Ática, 1990.

GREF: GRUPO DE REELABORAÇÃO DO ENSINO DE FÍsICA. Física 3: Eletromagnetismo. 4.ed. São Paulo: Edusp, 2000.

GUIMARÃES, L.A.M.; BOA, M.C.F. Física para $02^{0}$ grau, eletriciade e ondas. São Paulo: Harbra, 1998. v.3.

HALLIDAY, D.; RESNICK, R.; KRANE, K.S. Física 3. 4.ed. Rio de Janeiro: LTC Livros Técnicos e Científicos Editora S. A.,, 1996. v.3.

KALASHNINOV, S.G. Electricidad. México: D.F., Editorial Grijalbo, S.A., 1959.

KITTEL, C. Introdução à Física do Estado Sólido. Rio de Janeiro: Guanabara Dois, 1976. 
LIMA, M. C. B.; ALVES, L. A.; LEDO, M. R. A. G. Contando história... Apresentamos a Física. Caderno Catarinense de Ensino de Física, v.13, n. 2, p. 89-107, ago. 1996.

MATTHEWS, M. Construtivismo e o Ensino de Ciências: uma avaliação. Caderno Catarinense de Ensino de Física, v.17, n. 3, p. 270-294, dez. 2000.

MÁXIMO, A.; ALVARENGA, B. Curso de física. 5.ed. São Paulo: Scipione, 2000. v.3.

NUSSENZVEIG, H.M. Curso de Física Básica: Eletromagnetismo. 1.ed. São Paulo: Edgard Blücher, 1997. v.7.

PHYSICAL SCIENCE STUDY COMMITTEE. Física. Brasilia: Universidade de Brasília, 1967. pt. IV.

PIMENTEL, J. R. Laboratório de instrumentação para o ensino de física. Rio Claro: apostila, 1997.

PIROPO, B. Fitas e disquetes. Disponivel em: <http://uww.bpiropo.com.br/MC950220.htm>. Acesso em: 30 nov. 2001.

Princípios e Aplicações da Eletrônica. Trad. Ronaldo Sergio de Biasi. 4.ed. Rio de Janeiro: Record, 1980. (Eletricidade e Eletrônica), ४.1.

SALMERON, R.A. Introdução à Eletricidade e ao Magnetismo. 4.ed. São Paulo: s.ed., 1956. 
Question of the Day. How does a magnetic stripe on the back of a credit card work? Disponivel em: <http://uww.howstuffworks.com/question503.htm>. Acesso em: 30 nov. 2001.

SABA, M. M. E. A Física das Tempestades e dos Raios. Física na Escola, v.2, n. 1, p. 19-22, 2001.

SÃO PAULO. Secretaria da Educação. Coordenadoria de Estudos e Normas Pedagógicas. Subsídios para a implementação da proposta curricular de Física para o segundo grau; eletrodinâmica. São Paulo: SE/CENP, 1981.

SEARS, F.; ZEMANSKY, M.W.; YOUNG, H. D. Física: Eletricidade e Magnetismo. Rio de Janeiro: LTC - Livros Técnicos e Científicos Editora S.A., 1984.

SCHIEL, D.; TOMAZELLO, M.G.C, orgs. O livro da Experimentoteca: educação para as ciências da natureza através de práticas experimentais: roteiros. Piracicaba: Gráfica Editora Alves Piracicaba, 2000.

SILVA, L.C. M. Sala de Fisica. Disponivel em: <http://br.geocities.com/saladefisica/index.html>. Acesso em: 30 nov. 2001.

TIPLER, P.A. Eletricidade e Magnetismo. 3.ed. Rio de Janeiro: LTC - Livros Técnicos e Cientificos Editora S. A.,, 1995. v.3. 
TIPLER, P. A. Física Moderna: Mecância Quântica, Relatividade e a Estrutura da Matéria. 4.ed. Rio de Janeiro: LTC - Livros Técnicos e Científicos Editora S. A., 2000. v.3.

TORRES, C.M.A. et al. Física: ciência e tecnologia. São Paulo: Editora Moderna Ltda., 2001.

VALENTE, M.O., coord. Projecto Física, Luz e Electromagnetismo. Lisboa: Fundação Calouste Gulbenkian, 1995. v.4.

Usina Termelétrica de Santa Cruz. Disponivel em: <http://www.utesantacruz.hpg.ig.com.br/pre.htm>. Acesso em 30 nov. 2001. 


\section{ANEXOS}


O Enigma de Tales de Mileto 


\section{Caro Leitor}

A motivação desse trabalho é fornecer um material que estimule você, leitor, a conhecer os fascínios da ciência. Para isso, estamos apresentando, com naturalidade, por intermédio de experimentos simples, inseridos em uma narrativa ficcional, alguns conceitos complexos de física, sempre que possível associando-os com o cotidiano .

Esse livro é recomendado tanto para leigos a partir de 12 anos quanto para profissionais da área. Queremos deixar claro que a leitura do mesmo não dispensa o acompanhamento de um livro didático para um aprendizado mais profundo.

0 conteúdo do livro é apresentado por meio de questionamentos que as personagens fazem entre si $e$, quando não conseguem resolvê-los por si só, procuram um siłe, que conduzirá toda a história, sempre respondendo o necessário e propondo atividades com as quais serão esclarecidas as dúvidas. A história da eletricidade é apresentada no decorrer do texto pelos próprios personagens. Todos os experimentos propostos utilizam materiais simples e de baixo custo que foram rigorosamente testados a fim de estimular o interesse do leitor pela ciência.

Para um melhor aproveitamento do conteúdo do livro é recomendado que as atividades sejam efetuadas na ordem em que são sugeridas.

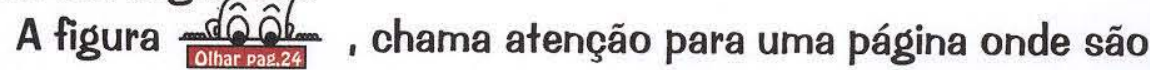
feitas recomendações sobre os materiais utilizados nas experiências e quando possível a substituição dos mesmos.

É importante ressaltar que, o sucesso das atividades descritas nesse livro deve-se a necessidade de manter bem seco o ambiente e os materiais utilizados nos experimentos.

Nesse fascículo você entenderá, por exemplo, o princípio de funcionamento da fotocopiadora Xerox e do pára-raios, entre outros fenômenos. Por isso, convidamos você, caro leitor, a viajar pelo mundo da eletricidade.

Vamos??? 


\section{OEnigma de Tales de Mileto}

Quatro adolescentes estavam conversando em uma lanchonete. Pedro, de 16 anos, um garoto curioso que cursa a $2^{\text {a }}$ série do ensino médio; Patrícia, de 15 anos, adora ler e cursa a $1^{2}$ série do ensino médio; Marcelo, de 15 anos, um adolescente que tem fascínio por computador, está na mesma sala de aula de Patrícia; e Tales, irmão de Marcelo, um menino de 12 anos, que cursa a $6^{\mathrm{a}}$ série do ensino fundamental.

No meio da conversa, Tales contou que na noite anterior estava navegando na Internet e encontrou a história de um filósofo matemático chamado Tales de Mileto. Devido à semelhança com seu nome, ele acabou se interessando pelo site. A história relatava um episódio que havia ocorrido em 600 a.C, quando Tales de Mileto, esfregando um pedaço de âmbar ("resina petrificada", isto é, um fóssil que também é usado, atualmente, como pedra preciosa na confecção de jóias. A resina é originária de árvores diversas), percebeu que ele atraía objetos leves como cabelos soltos, penas, etc., mas ninguém na época entendia por que isso acontecia.

Intrigados com aquela história, discutiram sobre 0 assunto por um longo tempo. Para finalizar a discussão, Pedro sugeriu que fizessem a experiência discutida no site (Atividade 01).

\section{FORÇA DE ATRAÇÃO}

\section{ATIVIDADE 01}

Você vai precisar de: 1 canudo de plástico usado para tomar refresco, papel picado e papel higiênico

\begin{abstract}
7 - Pique pedaços bem pequenos de papel comum (de jornal, por exemplol. Em seguida atrite fortemente um canudo com um pedaço de papel higiênico.
\end{abstract}
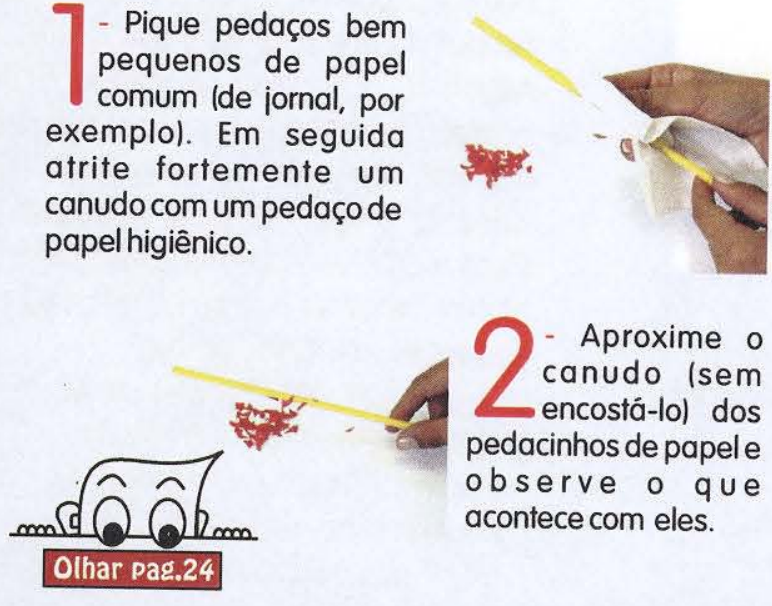

- Olhem que legal! Com esse canudo podemos atrair os pedacinhos de papel sem tocá-los - falou Tales - mas o que está causando isso?

Como ninguém conseguia responder a pergunta de Tales, Marcelo sugeriu enviar um e-mail para o site do professor LUIZ ANTÔNIO. Ali as pessoas deixavam suas dúvidas, via e-mail, e ele próprio, respondia a todas as perguntas.

No dia seguinte, os quatro amigos reuniram-se na casa de Marcelo para escrever para o Luiz Antônio. Primeiramente eles relataram a experiência e depois perguntaram que força era aquela que agia à distância, atraindo os papéis. Depois de algum tempo, naquele mesmo dia, os garotos foram ver se haviam recebido a resposta, e ali, na tela do computador, estava ela: não uma simples resposta, mas sim uma proposta feita pelo professor, a fim de deixar o interesse dos meninos mais aguçado. Ele propunha:

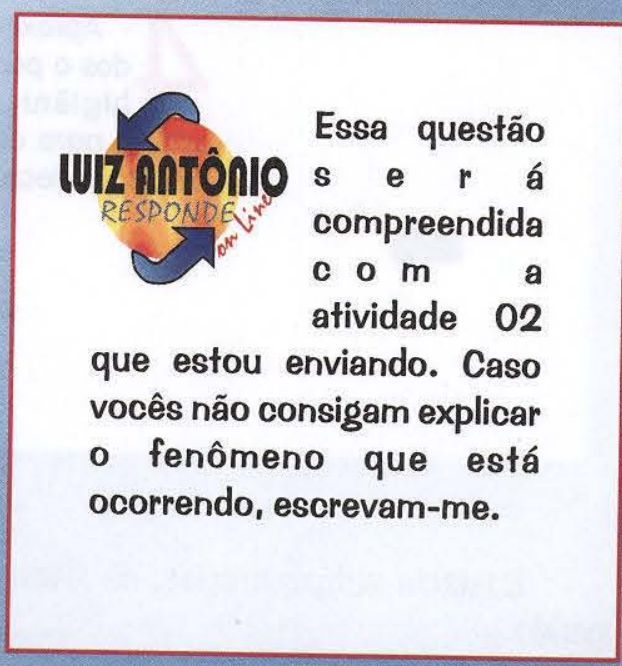




\section{FORÇA DE REPULSÃO}

\section{ATIVIDADE02}

Você vai precisar de: 2 canudos de plástico, linha e papel higiênico.

- Em cada extremidade do fio, amarre um canudo.

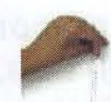

2

- Esfregue os canudos, um a um, com papel higiênico.

\footnotetext{
3
} -Suspenda-os de modo que estejam próximos. Observe que eles se afastam. Se o dia estiver úmido talvez a experiência não dê certo. Tente repeti-la em local mais seco.
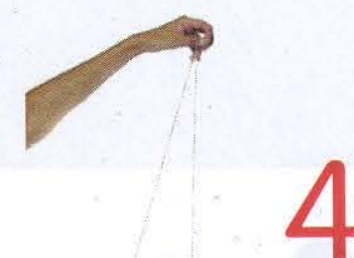
Aproxime dos canudos o pedaço de papel higiênico que você utilizou para esfregá-los.Veja oque acontece.

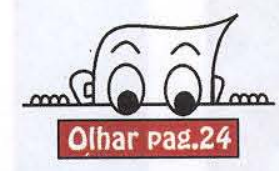
sugerido.

Bastante entusiasmados, os jovens fizeram o que foi

Páq.02
-Emais-ressaltou Patrícia-o canudo é atraido pelo papel higiênico que nós utilizamos para atritá-los.

- Agora eu estou com mais dúvidas disse Pedro. - Afinal, que força é essa que age à distância que ora afasta e ora aproxima os objetos?

Patrícia, à busca de uma explicação para as observações, foi à biblioteca pesquisar mais informações sobre o grande filósofo. Além de saber mais sobre o famoso matemático, acabou descobrindo muito sobre a eletricidade. Ao encontrar-se com Marcelo, Pedro e Tales, ela relatou suas descobertas.

- Tales de Mileto (546 - 624 a.C.) morreu sem entender o que fazia o âmbar atrair objetos leves e esse mistério permaneceu por cerca de 2000 anos. Em meados de 1570, William Gilbert (1544 - 1603) observou que vários materiais, como vidro e pele de animal, entre outros, possuiam a mesma propriedade do âmbar. Como em grego âmbar significa electron, Gilbert denominou os materiais que se comportavam como o âmbar de elétricos, surgindo, assim, expressões como eletricidade, força elétrica, etc..

EPatrícia prosseguiu:

- Mais tarde, Charles François Dufay (1602 - 1686) descobriu que, enquanto alguns objetos atraiam-se, outros se repeliam quando friccionados, como aconteceu com os dois canudos que foram atritados com papel higiênico.

Por muito tempo essas observações não passaram de truques de festas. Essa situação modificou-se bastante com o trabalho do inventor Benjamin Franklin (1706 - 1790), 0 qual acreditava que a eletricidade era um fluido muito leve, que faltava ou estaria em excesso nos corpos eletrizados. Ele sugeriu chamar o que ele julgou ser um excesso de fluido elétrico, de eletricidade positiva e a falta, de eletricidade negativa. Enunciou também a lei, agora conhecida como "conservação da carga elétrica", ou seja: a soma total das cargas elétricas dentro de uma região é constante. Essa teoria, embora hoje ultrapassada, estava bem próxima do que se comprovou mais tarde, com a descoberta do átomo.

- Átomo??? Pat você está falando grego... Explique-se- disse Tales.

- Átomo é a menor porção da matéria que caracteriza um elemento químico.Uma das maiores contribuições sobre sua estrutura foi 
dada já no início do século XX, por Ernest Rutherford (1871 - 1937) - explicou a garota. - Segundo ele, o átomo é semelhante ao sistema planetário, tendo um núcleo composto por partículas muito pequenas que são chamadas de prótons e de nêutrons, rodeados por elétrons que ficam girando em torno do núcleo, como tentei representar nesse desenho. As bolinhas amarelas são os elétrons, as bolinhas azuis, os prótrons e as bolinhas vermelhas, os nêutrons. continuou:

Animada com sua explicação, Patrícia Modelo atômico

\section{- Ah! Estava me esquecendo!}

Os prótons têm carga elétrica denominada positiva; tal como Franklin propôs;

Os elétrons têm carga elétrica denominada negativa;

Os nêutrons não têm carga.

E tem mais, o átomo em seu estado natural (neutro) possui a mesma quantidade de prótons e elétrons. Bem! Essas foram as informações que consegui nas minhas pesquisas, mas mesmo com todas elas eu não sei explicar nossas observações comentou Patrícia.

- Possofazer uma pergunta? -disse Tales, impaciente, e sem esperar a resposta, continuou. - Todos os objetos, como por exemplo essa cadeira é composta por átomos neutros?

- Correto! Tales - disse Patrícia.

- Pat, não fique desanimada - falou Pedro - porque as explicações para nossas questões não devem ser tão simples assim, sugiro escrever para o Luiz Antônio e dizer que observamos que ao atritar dois canudos com papel higiênico eles se afastaram e esses mesmos canudos atraem pedacinhos de papel. Resumindo, ora temos uma força de repulsão ora uma força de atração. chegar:

Foi o que fizeram. A resposta do professor não tardou a

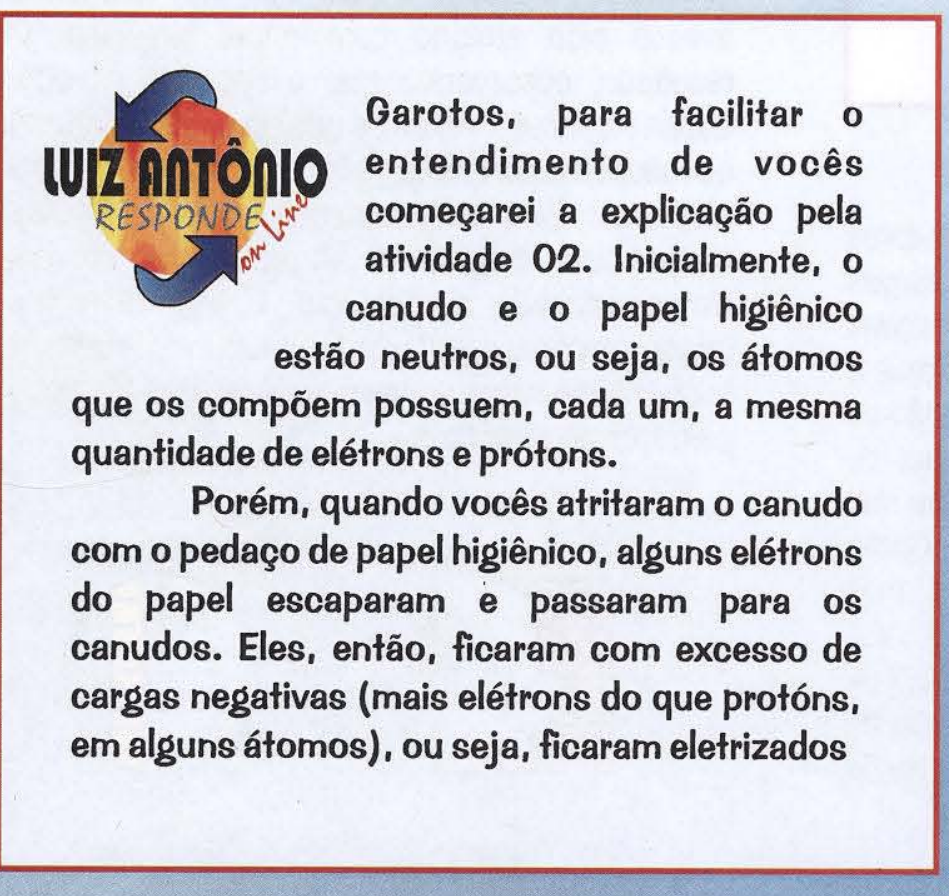

negativamente. Já o papel perdeu cargas negativas, ficando com excesso de cargas positivas, ou seja, ficaram eletrizados positivamente. Como essa eletrização ocorreu por fricção, chamamos esse processo de eletrização por atrito.

Com essa explicação, convencionou-se dizer que a força de repulsão, $F_{R}$, surgiu porque os canudos, atritados com papel, passaram a apresentar cargas negativas em excesso. Supõe-se então, como hipótese que as cargas de mesmo sinal levam os canudos a se repelir.

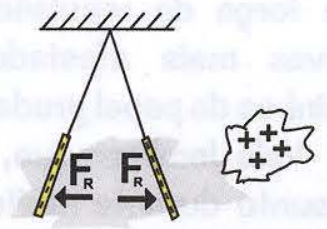

- mesmo não aconteceu quando vocês aproximaram o papel eletrizado positivamente do canudo eletrizado negativamente. Neste caso, criou-se uma força de atração,

$F_{a}$, entre eles. Concluímos então, que corpos com cargas de sinais opostos se atraem.

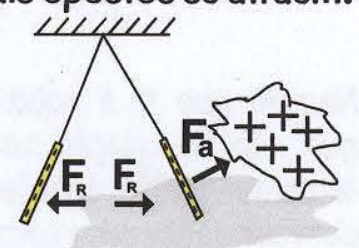

Agora vamos descrever o que ocorreu na atividade 01 , de acordo com as hipóteses dos cientistas.

Inicialmente os pedacinhos de papel estavam neutros, ao aproximar - canudo eletrizado 
negativamente dos pedacinhos de papel, ele provocou uma separação de cargas, isto é, repeliu no papel as cargas negativas para a extremidade oposta e os átomos da extremidade próxima passaram a apresentar um excesso de cargas positivas, como mostra a figura abaixo.

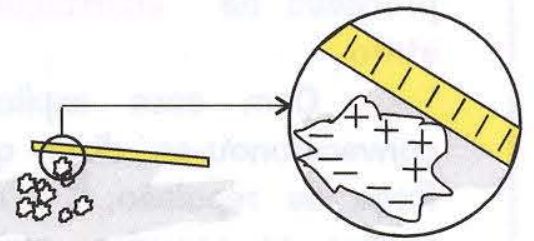

Note que houve apenas uma separação de cargas no papel e com isso ele continua neutro. Como as cargas positivas do papel estão mais próximas do canudo, a força de atração deste sobre elas será maior que a força de repulsão sobre as cargas negativas mais afastadas. Por isso, os pedacinhos de papel grudaram no canudo.

Vale lembrar que, vários estudiosos do assunto durante muitos séculos fizeram vários experimentos com diferentes materiais e foram pouco a pouco propondo explicações, verificando que elas não explicavam todas as observações, outros pesquisadores propunham novas idéias, até chegar às conclusões que descrevi, que são aquelas hoje aceiłas universalmente.

- Naquilo que já li sobre o assunto, os autores ressaltam que não há criação nem destruição de cargas elétricas - lembrou Patrícia, após ler o e-mail. - Como alguns elétrons podem ser deslocados com certa facilidade porque a força que os une aos protons é muito fraca, na eletrização do canudo,ocorreu apenas uma transferência de elétrons do papel para o canudo, permanecendo inalterada a soma das cargas elétricas do conjunto (canudo e papel). Como Benjamin Franklin já tinha dito há muitos e muitos anos atrás.

Patricia! Será que agora eu posso falar? perguntou Tales irritado. - Olhem que interessante, depois de algum tempo os pedacinhos de papel caem do canudo, vocês sabem explicar por que eles não continuam presos?

Páq.04
- Os papéis soltaram porque houve passagem de cargas negativas do canudo para os pedacinhos de papel, assim ambos ficaram com cargas negativas. Como cargas iguais se repelem os pedacinhos de papel saltaram do canudo - respondeu Pedro, com um livro na mão, onde encontrou a explicação para a dúvida de Tales.

- Legal! - exclamou Tales. - Você está aprendendo tudo direitinho!!!!

Tales, brincando com um canudo que ele tinha eletrizado, encostou-o na parede (Atividade 03).

\section{CORPO ELETRIZADO ATRAI CORPO NEUTRO?}

\section{ATIVIDADE 03}

Você vai precisar de: 1 canudo de plástico e papel higiênico.

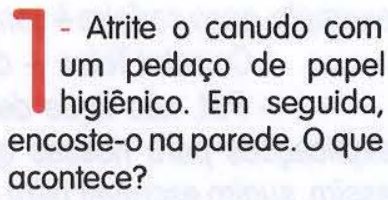
acontece?
Tales ficou espantado quando viu o canudo grudado na parede. Então, Pedro pediu que ele colocasse na parede um outro canudo que ainda não tivesse sido atritado com papel higiênico. Como resultado, observaram que o segundo canudo não aderia na parede. Antes de qualquer comentário, Pedro questionou o porquê daquilo, mas Tales não soube lhe responder. Ele insistiu para que o amigo tentasse pelo menos um palpite e sugeriu que começasse esquematizando o problema. E imediatamente ele pegou um papel e um lápis, lembrando da explicação do Luiz Antônio sobre a atração dos pedacinhos de papel pelo canudo eletrizado.

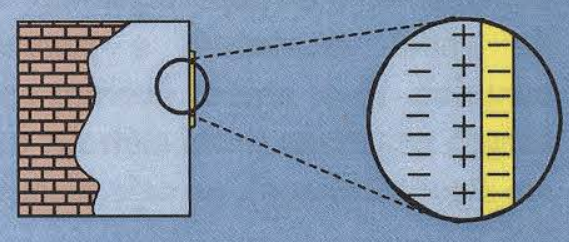


- Ah! Com um desenho semelhante do Luiz Antônio, estou conseguindo entender o que está acontecendo-disse Tales. - O canudo eletrizado negativamente repeliu as cargas negativas na superfície da parede, fazendo com que alguns átomos, nela, próximos ao canudo ficassem com excesso de cargas positivas. Assim, a força de atração será maior do que a força de repulsão e, por isso, o canudo aderiu na parede.

- Viu como basta apenas um pouco de persistência para entender aquilo que não compreendemos à primeira vista??? - falou Pedro.

- Eh, mas vocêe é "metido"!!! - brincou Patrícia.

- Mas agora quem tem uma dúvida sou eu - disse Pedro. Como se faz para saberque o corpo possui cargas elétricas?

Ninguém soube responder e então procuraram o Luiz Antônio para perguntar.

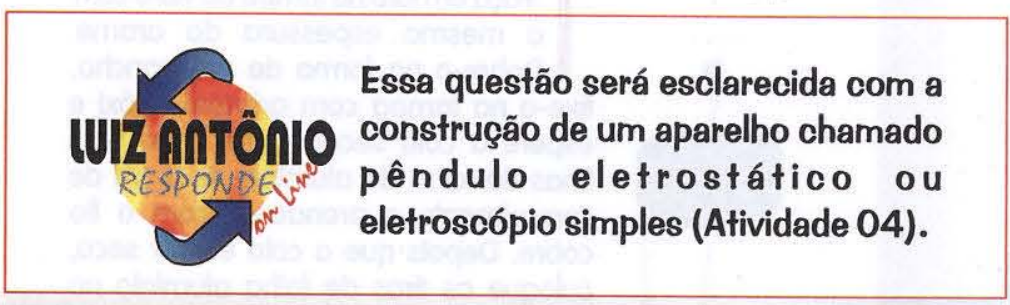

\section{DETECTOR DE CARGAS "PÊNDULO ELETROSTÁTICO"}

ATIVIDADE 04

Você vai precisar de: 2 canudos de plástico sanfonados, linha, folha de alumínio, papel higiênico, isopor, fita adesiva e tesoura.

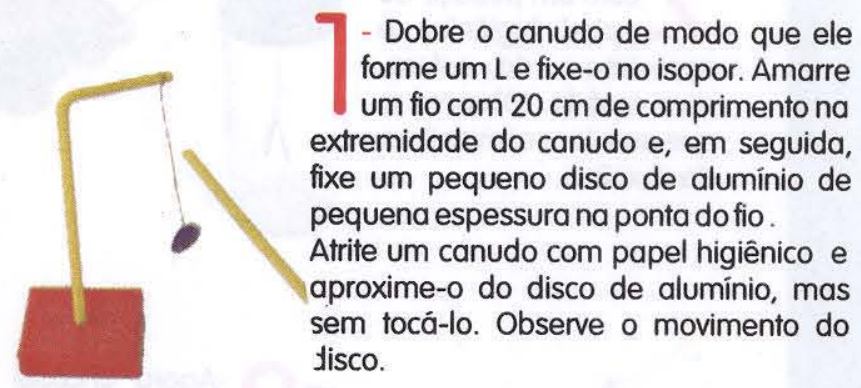

Agora encoste o canudo atritado no disco de alumínio. Qual será então, o sentido do movimento do disco? Tentem explicar o ocorrido.
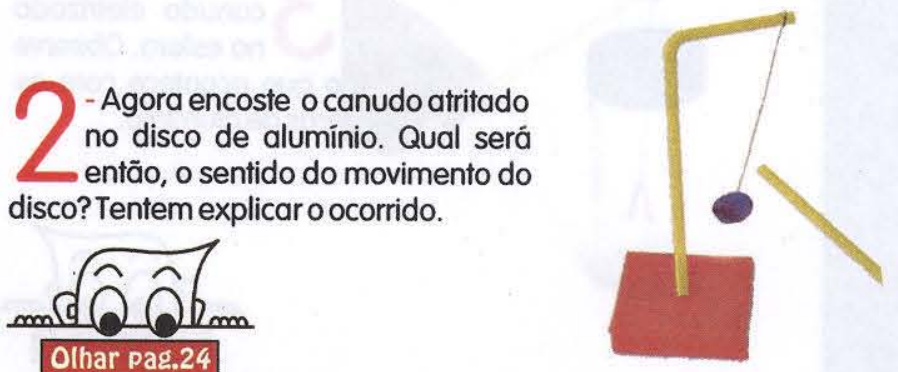

Mais uma vez os garotos foram executar a tarefa proposta no site.

Reuniram-se na casa do Marcelo para montar o pêndulo e o local passou a ser o ponto de encontro deles, pela comodidade de ter um quarto desocupado no fundo da casa.

- Que barato! 0 canudo atrai o disco. Olhem! Agora o disco está fugindo do canudo. Vocês sabem me explicar o que está ocorrendo? - gritou Tales.

Pedro, muito cauteloso, pediu a Tales que aproximasse um canudo neutro (que não tivesse sido atritado) do disco e só depois diria alguma coisa. Tales, naquele mesmo instante, pegou o canudo e fez como Pedro tinha sugerido e observou que o disco ficava parado.

- Ora vejam só! - falou Tales, todo empolgado. - Esse pêndulo é um detector de cargas, afinal se o disco estiver eletrizado, qualquer corpo que chegarperto vai atraí-lo.

- Muito bem! - aprovou Pedro. Procurei ler um pouco sobre esse assunto em um livro de fisica e, descobri que seria impossivel aprender tudo sozinho. Mas, por sorte, eu encontrei a explicação para esse fenômeno. Epara facilitar 0 entendimento explicarei 0 porquê disso fazendo esquemas.

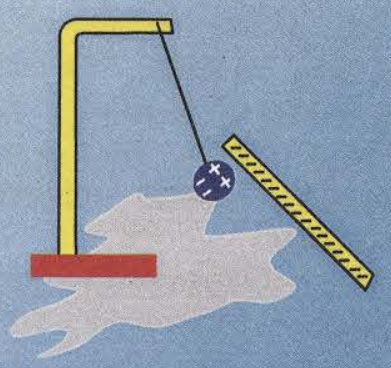

- Quando aproximamos o canudo eletrizado negativamente do disco de alumínio, as cargas se separam na superfície do disco, tal como no caso da parede. O canudo eletrizado 
negativamente repele as cargas negativas existentes no disco, criando assim uma região com cargas positivas próxima ao canudo e uma região oposta com cargas negativas. Como as cargas positivas estão mais próximas do canudo, a força de atração será maior do que a força de repulsão, causada pelas cargas negativas, por isso o disco é atraído pelo canudo.

- Pedro! Pode deixar que agora eu explico o porquê do disco ser repelido pelo canudo - disse Marcelo, que até o momento só tinha observado as discussões.

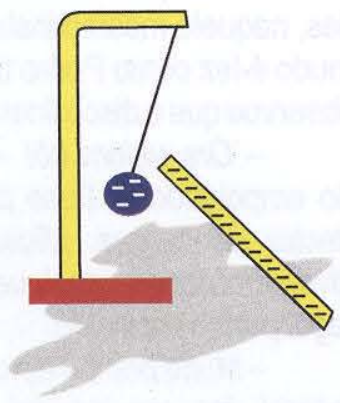

- Quando o disco toca o canudo, ocorre uma passagem de cargas negativas do canudo para ele. Assim, esse disco fica com excesso de cargas negativas e, como ambos estão carregados negativamente, eles se repelem. 0 canudo continua negativo porque possui grande excesso de elétrons e mesmo perdendo alguns para o disco ainda continua eletrizado negativamente.

- Gente! - Patrícia chamou a atenção dos colegas. - Eu estava pensando, será que esse é o único aparelho que detecta cargas?

Como ninguém sabia responder sua pergunta ela se propôs a procurar a resposta e trazê-la no dia seguinte. E assim ela fez, levou todo o esquema para a construção de um aparelho chamado eletroscópio de folhas e comentou:

- O inventor do eletroscópio de folhas foi Francis Hausksbee ( ? - 1713) em meados de 1700. A montagem que o livro sugeriu é bastante simples. Antes que me perguntem, há outros detectores de cargas, como por exemplo 0 eletrômetro.

Logo que Patricia terminou sua explicação começaram a montar 0 Experimento (Atividade 05).

\section{DETETOR DE CARGAS "ELETROSCÓPIO DE FOLHAS"}

ATIVIDADE 05

Você vai precisar de: $13 \mathrm{~cm}$ de arame fino, $1 \mathrm{~cm}$ de fio de cobre (número 28), folha de aluminio, um vidro, 1 bolinha de isopor, adesivo epóxi, 1 canudo de plástico e papel higiênico.

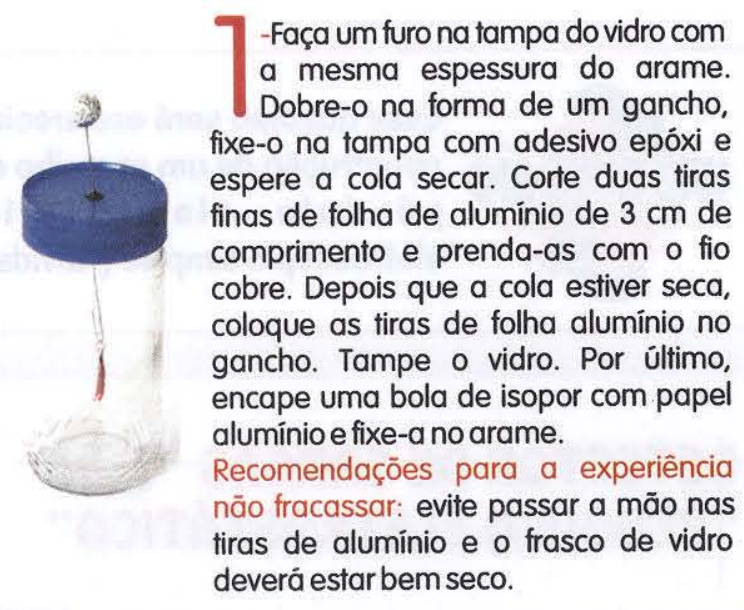

2

Atrite o canudo com um pedaço de papel higiênico e aproxime-o da esfera, sem tocá-la. Observe o que acontece com as tiras de aluminio.
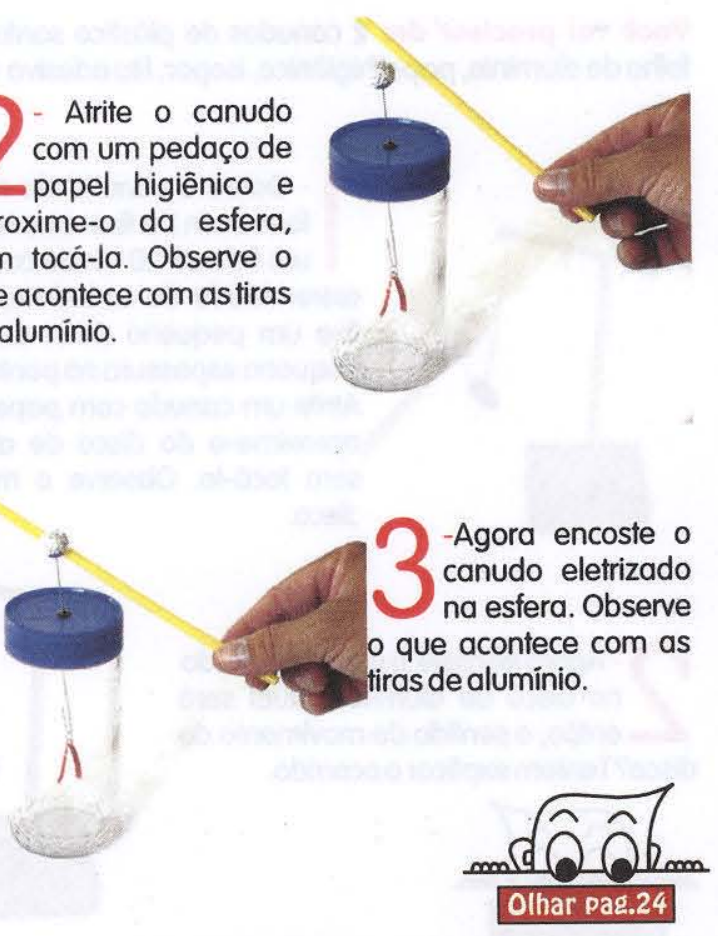
No começo eles tiveram alguns problemas na montagem do eletroscópio, pois o frasco estava úmido, consequentemente $\mathrm{o}$ ar no seu interior tornouse condutor impedindo que as tiras de folhas de alumínio se afastasse, mas com persistência conseguiram fazê-lo funcionar.

Perceberam que as tiras de alumínio afastavam-se umas das outras, ao aproximar ou encostar o canudo eletrizado na esfera encapada com alumínio.

Marcelo comentou que tinha visto aquele aparelho em uma feira de ciência na escola e foi logo explicando o funcionamento do eletroscópio.

- É simples! Quando aproximamos o canudo eletrizado negativamente à esfera, as cargas negativas da esfera são repelidas e acumulam-se nas tiras de alumínio. A esfera então apresenta excesso de cargas positivas e as tiras excesso de cargas negativas. Como as duas tiras ficam eletrizadas com cargas de mesma natureza, elas se separam, por causa da força de repulsão existente entre elas.

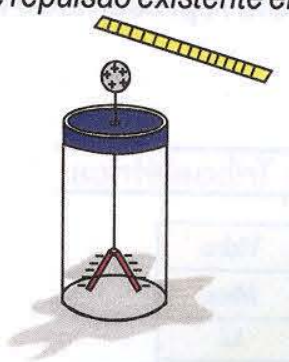

É interessante notarque, ao afastar o canudo eletrizado do eletroscópio, as tiras juntam-se novamente, porque as cargas se redistribuem voltando às posições anteriores à aproximação do canudo e assim o conjunto (eletroscópio) apresentasenovamente neutro. Entendeu?

Após a pergunta o garoto continuou sem esperar a resposta dos colegas:

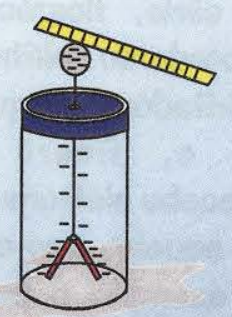

- Já quando encostamos o canudo eletrizado negativamente na esfera, cargas negativas do canudo são transferidas para ela. Com isso, tanto a esfera quanto as tiras ficam com excesso de cargas negativas e, conseqüentemente, as tiras se separarão. Observe que afastando o canudo, as tiras continuam separadas porque eletrizamos 0 eletroscópio por contato, isto é, houve transferência de carga do canudo para a esfera e dela para as tiras de alumínío.

Marcelo então complementa:

- Quando me explicaram na feira de ciências eu não tinha entendido, mas agora com tudo que já aprendemos posso compreender oque me falaram. Marcelo

Pedro, muito curioso e interessado, perguntou a

- Mas depois que o eletroscópio estiver eletrizado, 0 que eu faço para as tiras se juntarem novamente?

- É simples, basta encostara mãona esfera. Patrícia.

- Marcelo você poderia explicar melhor? - pediu

- Claro! Quando se encosta a mão na esfera eletrizada, os elétrons em excesso, escoam pelo seu corpo até a Terra, assim a esfera fica neutra.

- A Terra ficará eletrizada?-estranhou Tales.

- Não - respondeu Marcelo. - Como a Terra possul um enorme volume, 0 efeito das mesmas torna-se imperceptivel, pois a carga vai se espalhar por toda a superfície da Terra.

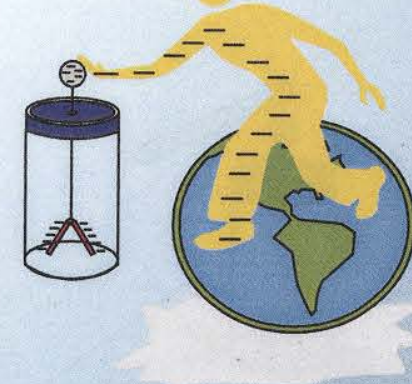

- Ah! Agora eu vou te pegar - disse Pedro desafiando Marcelo. - Como eu neutralizaria o eletroscópio se ele estivesse eletrizado positivamente?

- Da mesma forma, encostando a mão na esfera mas, nesse caso, os elétrons livres da Terra passariam através do seu corpo até a esfera, neutralizando-a respondeu Marcelo, todo confiante.

- Marcelo, com esse eletroscópio podemos determinar o sinal da carga de um objeto eletrizado? perguntou Patricia.

- Podemos sim - explicou ele. Como exemplo vamos eletrizar um canudo de plástico com papel higiênico, afinal já sabemos que o canudo fica eletrizado negativamente. Em seguida encostaremos o canudo na esfera encapada com alumínio. Assim estaremos eletrizando negativamente o eletroscópio, por contato.

Faremos dois testes: primeiro aproximaremos um canudo do eletroscópio eletrizado com excesso de cargas negativas na esfera do aparelho. 


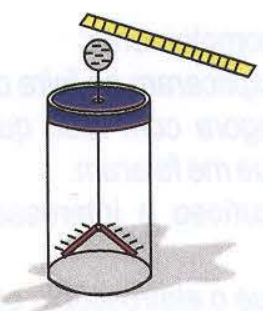

Percebem que as tiras se afastam ainda mais? - disse Marcelo fazendo uma demonstração. - As cargas negativas que estão na esfera tendem a ficar o mais distante possivvel do canudo, acumulando-se nas tiras. Recebendo mais cargas as tiras se afastam mais, pois a força de repulsão aumenta como procuraremos entender com outra experiência.

Agora, vejamos o que acontece com as tiras do eletroscópio, quando aproximamos da esfera um bastão de vidro que foi eletrizado com papel higiênico.

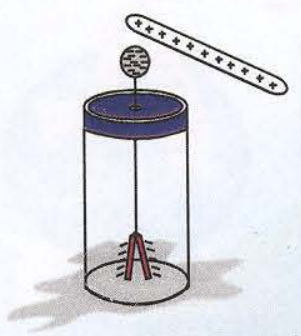

- As tiras ficaram mais próximas - falou Patrícia, após a demonstração de Marcelo. Tales.

- Por que isso aconteceu? - perguntou

- Veja bem! 0 bastão de vidro fica eletrizado positivamente e atrai mais cargas negativas para a esfera. Com isso as tiras ficaram com menos cargas negativas e, consequentemente a força de repulsão entre elas diminui e elas aproximam - respondeu Marcelo.

- Eu tenho uma dúvida! - exclamou Pedro. - É possivel um canudo plástico eletrizarse positivamente?

- Isso eu não sei responder, vamos escrever para o Luiz Antônio e fazer essa pergunta-sugeriu Marcelo.

Páq.,08

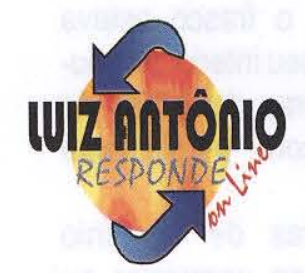

Um mesmo objeto poderá eletrizar-se por atrito positivamente ou $n$ e $g$ a $t i$ v a m e $n+e$ depedendo do material com o qual foi atritado.

Por exemplo: o canudo de plástico quando atritado com o papel, fica eletrizado negativamente. Já o bastão de vidro quando atritado com o papel, fica eletrizado positivamente. Isso ocorre porque o papel cede elétrons para uns e retira elétrons de outros.

Por volta de 1760, J.C. Wilcke observou que os materiais poderiam ser dispostos em uma seqüência em função de sua capacidade de ganhar ou perder elétrons, como está representado abaixo.

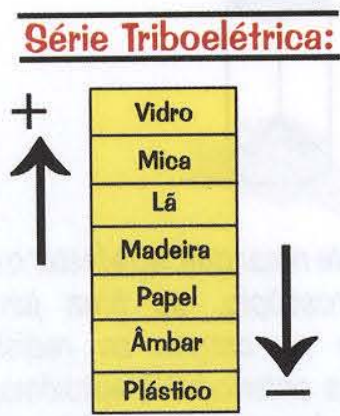

Atritando esses materiais entre si, verifica-se que os materiais que estiverem mais acima na série, ficarão eletrizados positivamente (perderão elétrons para o outro), quando atritados com qualquer outro que 0 segue e, ficará eletrizado negativamente (recebe elétrons do outro) ao ser atritado com aqueles que os precedem. Tomemos como exemplo o papel: quando atritado com o canudo de plástico, fica eletrizado positivamente, ou seja, o papel doa elétrons para o canudo. 0 contrário acontece quando o papel é atritado com vidro, ele fica eletrizado negativamente, ou seja, rouba elétrons do vidro.

Essa seqüência é chamada de triboelétrica. 
Assim que leram a explicação vinda do site, Pedro fez uma pergunta.

- Nós aprendemos a eletrizar um objeto, por atrito e por contato, será que existe outro processo de eletrização?

- Eu estou tão cansada que não consigo mais pensar, vamos pensar nisso amanhã - falou Patrícia, com a bolsa na mão a caminho da porta.

- Concordo com a Patrícia disse Marcelo.

- Eu não acredito! - exclamou Pedro, revoltado.

Mesmo insistindo muito, Pedro não conseguiu convencê-los a ficar. No dia seguinte, ele foi o primeiro a chegar na casa de Marcelo, tal era sua empolgação. Começaram a discussão a partir de sua pergunta, mas depois de um tempo perceberam que o melhor a fazer era encaminhar a pergunta para o site.

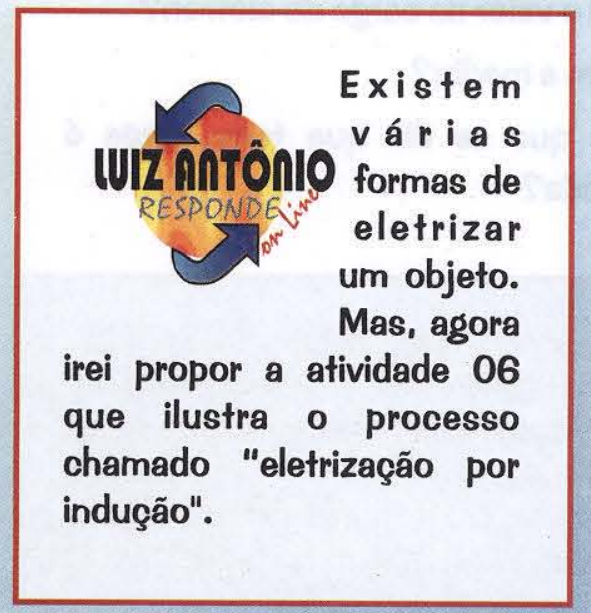

\section{ELETRIZAÇÃo POR INDUÇÃO}

ATIVIDADE 06

Você vai precisar de: Cartolina, 1 tira de papel de seda, 2 canudos de plástico, isopor, cola branca, fita adesiva, tesoura e papel higiênico.

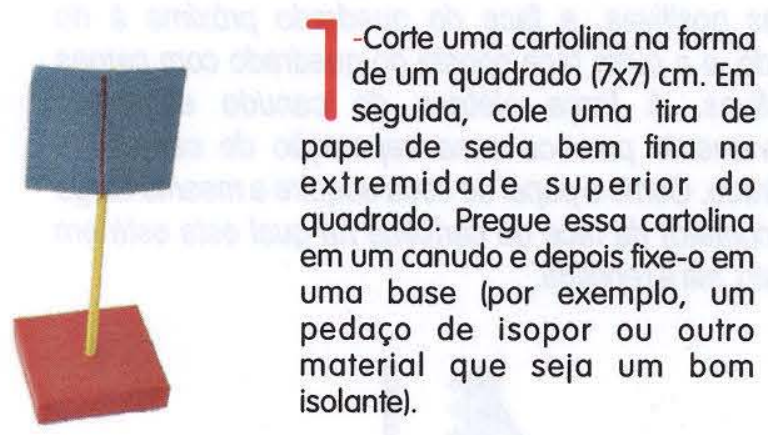

2

- Depois, atrite outro canudo com papel higiênico e aproxime-o do lado contrário de onde foi colada a tira de papel de seda sem encostar na cartolina.

Dizemos que o canudo é o indutor e o papel de seda vão ser eletrizado por induçāo. Nestas condiçōes observem o que ocorre com a tira de papel de seda. Tente explicar o ocorrido.

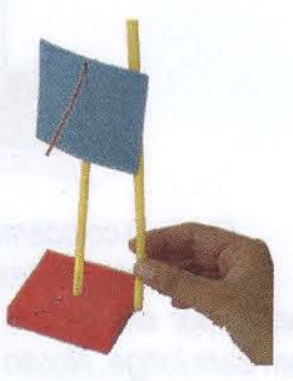

3 - Mantendo o canudo, sempre próximo do quadrado na mesma posição, encoste o dedo na parte da frente da cartolina. $O$ que ocorre com a tira de papel deseda?

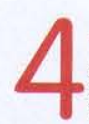

-Depois afaste o dedo e em seguida, afaste o canudo. Observe agora o que acontece com a tira de papel de seda. Tente explicar cada fase desta experiência.

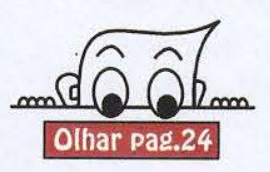

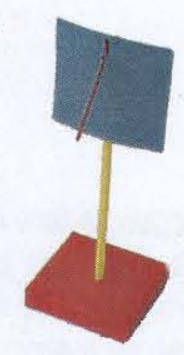


- Oh! - exclamou Tales, encantado. - A tira permanece levantada, mesmo depois que eu afastei 0 canudo. Mas eu não entendi esse processo de eletrização! O que aconteceria se eu tirasse primeiro 0 canudoe depoiso dedo?

- A forma mais simples de você descobrir é fazendo- comentou Pedro.

-Éprajá-falou Tales como canudo na mão.

Tales logo descobriu que a tira não se levantava.

- Vamos pensar! - disse Pedro, fazendo esquemas. - Quando aproximamos o canudo do quadrado estamos criando duas regiões, uma região com cargas positivas, a face do quadrado próxima à do canudo, e a outra face oposta do quadrado com cargas negativas. A força elétrica do canudo eletrizado negtivamente provoca essa separação de cargas no quadrado. Como o papel de seda adquire a mesma carga (por contato) da face da cartolina na qual esta está em contato, ela é repelida.

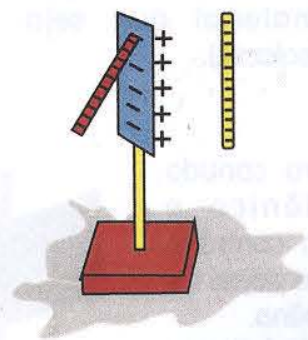

Quando colocamos o dedo na parte do quadrado com excesso de elétrons, as cargas negativas se escoarão por ele, pois o canudo as repelirão para que fiquem bem longe. Nosso corpo se presta a isso levando as cargas negativas em excesso para o chão. Depois que afastamos o dedo, elas não poderão mais retornar à cartolina. A carga negativa na tira de papel de seda também se escoa e ela encosta novamente na cartolina.

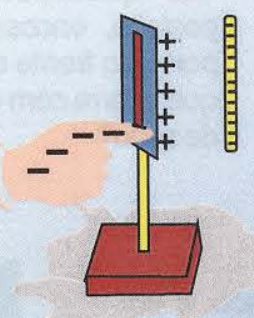

A seguir, a face da cartolina que perdeu elétrons também fica eletrizada positivamente. Vale lembrar que são os elétrons que se movem para que isto aconteça. Como cargas de mesma natureza se repelem, a tira se afasta do quadrado como mostra a figura.

Pag.10

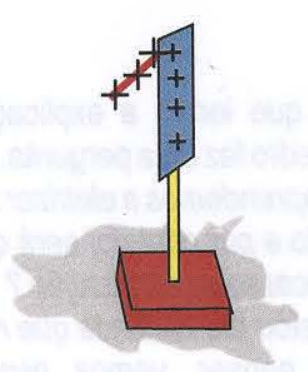

- Um desenho sempre ajuda a entender melhoro processo-comentou Pedro.

- Temos que concordar, afinal você resolveu o problema sem precisar recorrer ao Luiz Antônio. Mas vamos recorrer ao site para verificar se sua explicação está correta-disse Marcelo.

Todos concordaram.

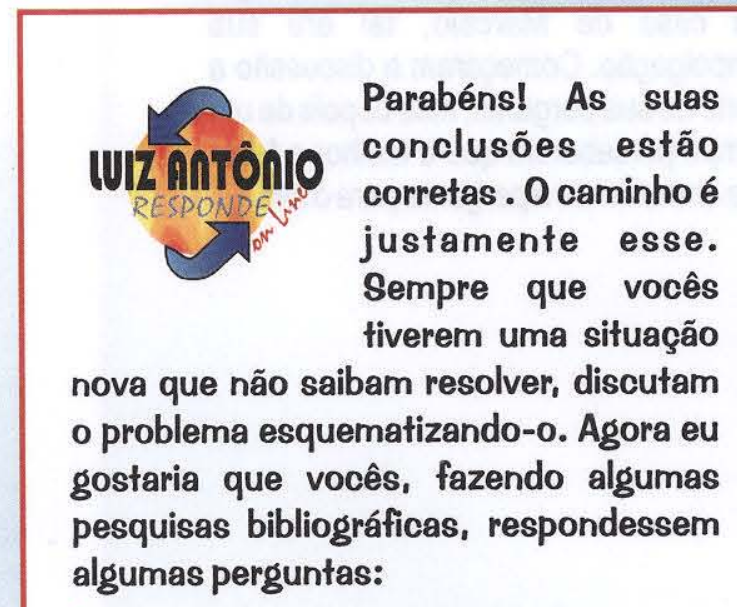

1- Quem é mais pesado o próton ou o elétron?

\section{2- Qual o valor da carga do elétron?}

\section{3- Quem a mediu?}

4- Por que se diz que toda carga é quantizada?

- É pessoal! - disse Marcelo depois de ler o email. - Teremos que ir até à biblioteca para procurar as respostas para essas questões, e depois podemos passarna soverteria, o que acham?

- Estou pronto, quando partimos? perguntou Tales, afinal tinham dito a palavra mágica "sorvete".

$\mathrm{Na}$ biblioteca, Patricia obteve as respostas com facilidade e explicou para os colegas:

- Aqui estão as respostas que procuramos Patricia toda empolgada leu uma a uma. 
1) A massa do próton é $1,7 \times 10^{-27} \mathrm{~kg}$ e a massa do elétron é $9,1 \times 10^{-31} \mathrm{~kg}$. Como vocês podem percebera massa do próton é muito maior, cerca de 2000 vezes maior do que a massa do elétron.

\section{2) O valor da carga do elétron, e, édada por:}

$$
\left(e=1,6 \times 10^{-19} \mathrm{C}\right)
$$

A carga do elétron é a menor carga que foi possivel medir (até a pouco tempo). A unidade para medir carga, o Coulomb, representada por C, foi criada em homenagem ao fisico francês, Charles Augustin Coulomb (1736 - 1806), pois ele conseguiu determinar a fórmula para calcular a intensidade da força elétrica entre corpos eletrizados.

3) O valor da carga elétrica do elétron também denominada carga elementar foi medido em 1911 pelo físico norte-americano Robert Andrews Millikan (1868 - 1953).

4) Um canudo eletrizado possui um número de cargas em excesso que é sempre um múltiplo inteiro do valor da carga do elétron, por isso dizemos que a carga elétrica é quantizada sempre que a carga elétrica de um objeto varia (aumenta ou diminui) essa variação se observa por um número inteiro de elétrons. Por exemplo, quando atritamos um objeto tiramos ou liberamos um número inteiro de elétrons. E pode ser calculada da seguinte forma:

$$
Q=N \cdot e
$$

Sendo e a carga do elétron, $\mathbf{N}$ um número inteiro qualquer, isto é, $\mathrm{N}=1000,2000,3000 \ldots$ Esse fato foi comprovado por Millikan quando mediu a carga do elétron.

Marcelo muito atento na explicação da colega, mal pôde esperar Patrícia terminar sua explicação para perguntar:

- Qual é a fórmula descoberta por Coulomb que calcula a intensidade da força elétrica?

- Não sei - falou Patrícia. - Mas podemos escrever para o Luiz Antônio contando que conseguimos responder todas as suas perguntas e depois aproveitamos para fazer a pergunta de Marcelo.

-Boa idéia! - disse Marcelo.
A resposta para essa dúvida será dada gradativamente. Estou enviando uma atividade para que vocês possam, depois de realizá-la, concluir se a força elétrica depende da quantidade de cargas existentes no material eletrizado.

\section{FORÇA DE COULOMB}

ATIVIDADE 07

Você vai precisar de: 2 canudos de plástico, linha e papel higiênico.

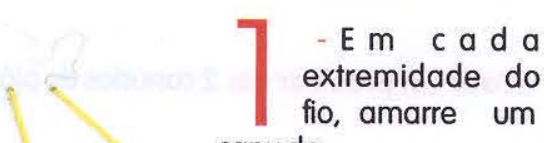
canu do. emidade do fio, amarre um

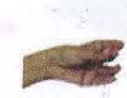

-Atrite somente metade
dos canudos separada-
mente com um pedaço de papel higiênico.

Suspenda-os e observe o afastamento dos canudos (ângulo que farão entre si).

Agora atrite os canudos por inteiro. E $m$ s e guida. suspenda-os e observe o novo afastamento dos canudos. 
- Já sei, o que o Luiz Antônio gostaria que observássemos - explicou Pedro. - A força de repulsão depende da quantidade de cargas em excesso. Afinal, os canudos que foram atritados pela metade, afastaram-se menos do que os atritados por inteiro porque têm menos cargas em excesso. conclusões.

- É verdade! - exclamou Patrícia. - Agora nós devemos enviar um e-mail para o Luiz Antônio contando essas

-Épra já!-disse Marcelo, em frente ao computador.

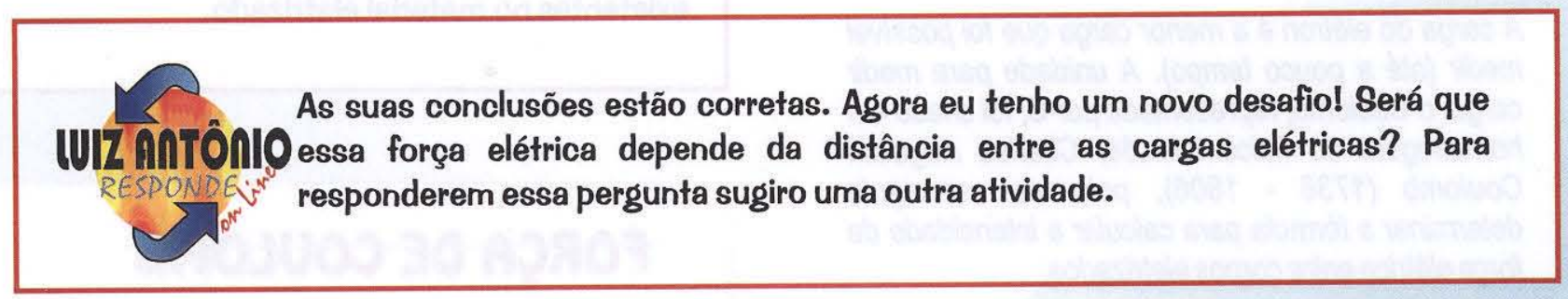

\section{FORÇA DE COULOMB}

Você vai precisar de: 2 canudos de plástico, linha e papel higiênico.

-Amarre um canudo na ponta da linha e atrite-o com um pedaço de papel higiênico. Suspenda-o.
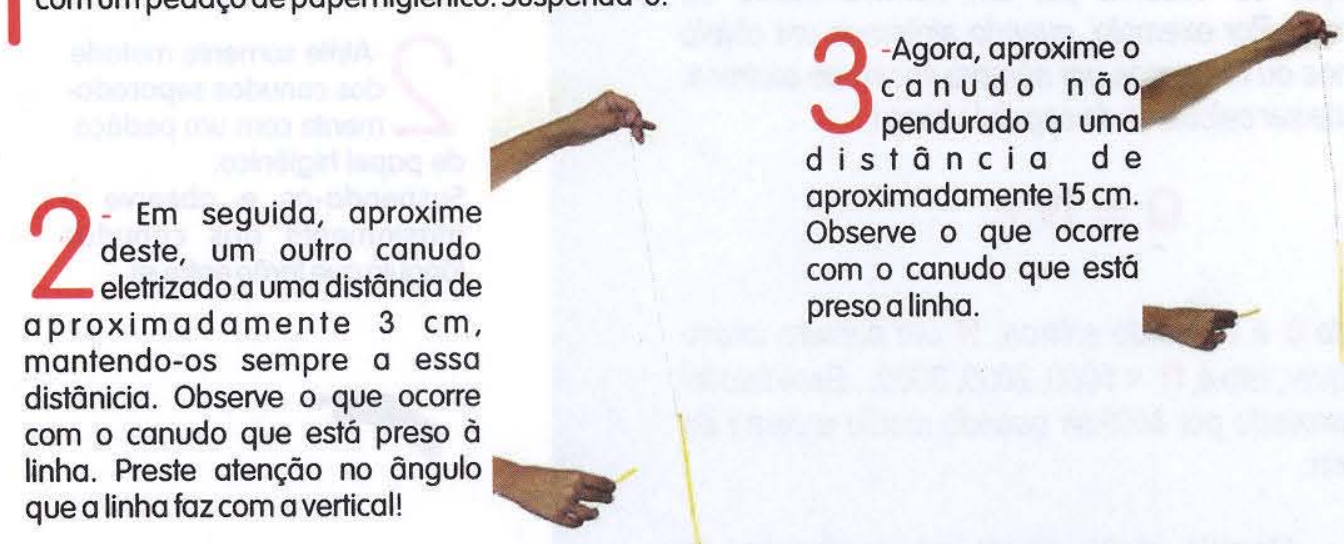
mantendo-os sempre a essa distânicia. Observe o que ocorre que a linha faz com a vertical!

Logo após lerem o e-mail, começaram a executar as tarefas propostas no site.

- Olhem que barato! - disse Marcelo, chamando a atenção dos colegas. - Conforme eu aumento a distância entre os canudos, a força de repulsão diminui, pois o canudo pendurado fica mais próximo da vertical.

- Vamos contar para o Luiz Antônio que descobrimos que a força elétrica depende também da distância entre as cargas elétricas!-exclamou Tales.

Paq.12 
- Calma, calma! - disse Pedro. - Antes, vamos tentar descobrir a intensidade da força elétrica. Afinal, não era essa a nossa dúvida inicial?

Pensaram, pensaram... Por um bom tempo, porém não conseguiram equacionar a dependência da força elétrica com a quantidade de cargas em excesso e a distância entre elas, descobriram apenas que a distâncias maiores a força de repusão é menor.. Então, procuraram o Luiz Antônio para pedir ajuda.

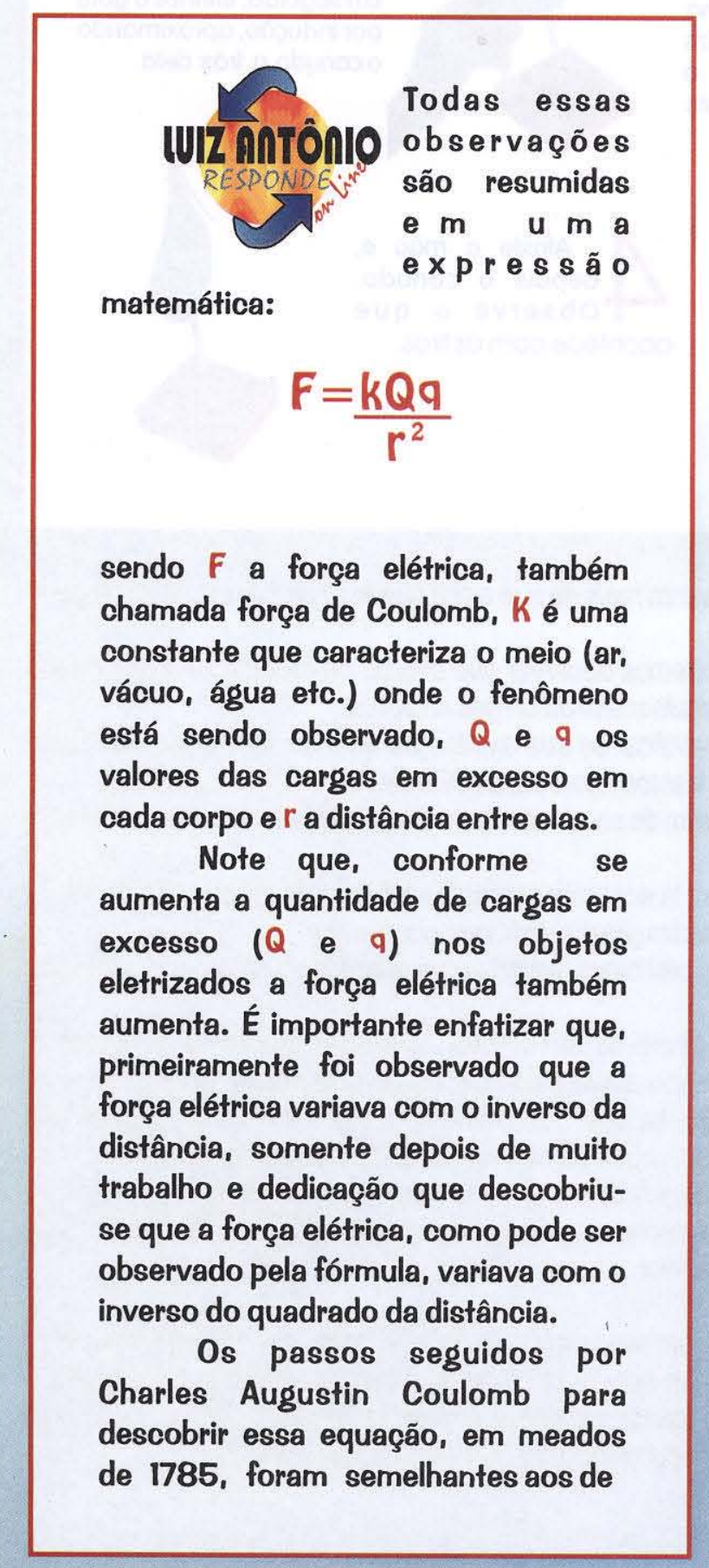

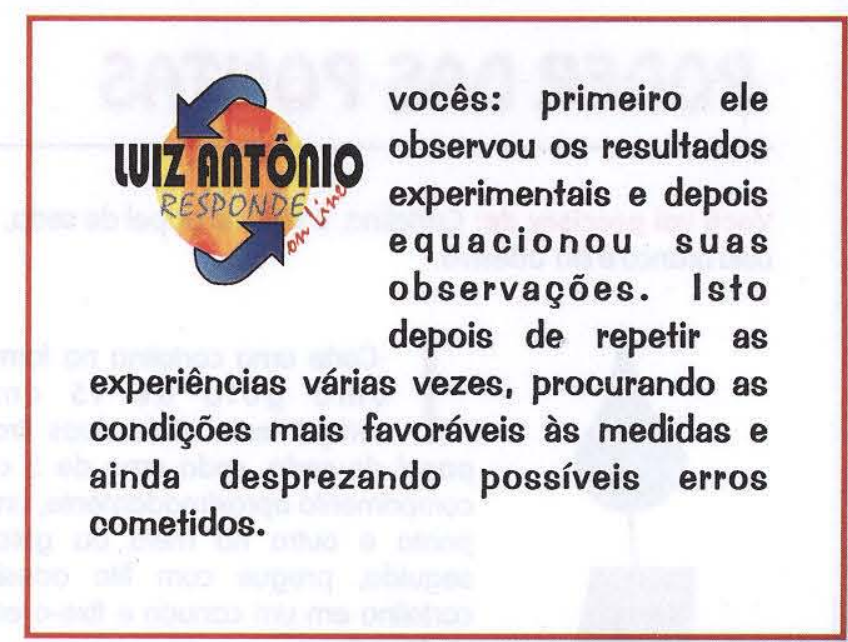

Inesperadamente, o pai de Marcelo, uma pessoa de pouco estudo mas muito curioso, entrou no quarto para avisá-lo que iriam viajar no outro dia, logo cedo, e retornariam somente na semana seguinte. Instantaneamente, os garotos começaram a se despedir. Marcelo insistiu para que ficassem, mas de nada adiantou. Combinaram de se reencontrarem ali mesmo assim que ele voltasse.

Após uma semana lá estavam eles, reunidos novamente. Entre uma história e outra, Marcelo contou para seu pai durante a viagem sobre o que estavam descobrindo nas suas brincadeiras e surgiu uma dúvida. eletrizado?

- Como as cargas se distruibuem em um objeto

- Boa pergunta! - disse Pedro. - Eu não tinha pensado nisso. Mas mesmo que tivesse também não saberia responder. Por acaso vocês sabem?

- Não!!! - responderam juntos Tales e Patrícia.

Então, decidiram enviar a pergunta para o site, a fim de esclarecer a dúvida de Marcelo.

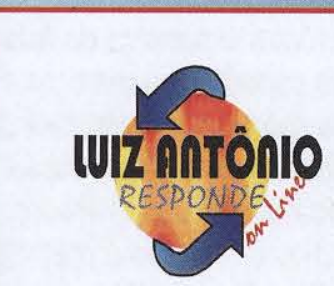

Vocês esclarecerão essa dúvida depois que executarem a atividade que estou enviando. Para que a experiência seja bem entendida, proponho que procurem o título "poder das pontas" e leiam o que ali estiver explicado sobre este fenômeno. 
Você vai precisar de: Cartolina, 2 tiras de papel de seda, 2 canudos de plástico, isopor, papel higiênico, tesoura, cola branca e fita adesiva.

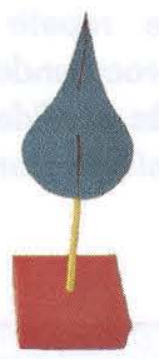

-Mantendo o canudo na posição recomendada. encoste a ponta do seu dedo na frente da gota.
-Corte uma cartolina na forma de uma gota de $15 \mathrm{~cm}$ de comprimento. Cole duas tiras de papel de seda, cada uma de $5 \mathrm{~cm}$ de comprimento aproximadamente, uma na ponta e outra no meio da gota. Em seguida, pregue com fita adesiva a cartolina em um canudo e fixe-o em um pedaço de isopor.

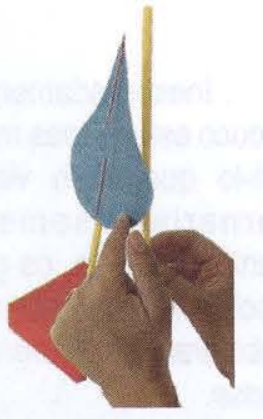

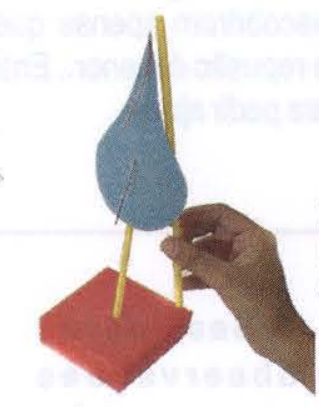

- Atrite um canudo com um pedaço de papel higiênicao. Em seguida, eletrize a gota por indução, aproximando o canudo a trás dela.

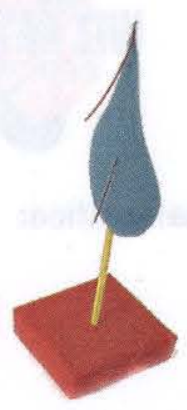

- Que engraçado! - exclamou Tales. - A tira da ponta levanta mais do que a tira que está presa no centro da gota! Porque isso acontece?

- Isso é um caso curioso! - concordou Pedro. - Nós podemos observar que a força de repulsão é maior na tira presa na ponta do que no centro, consequentemente tem um acúmulo maior de cargas na ponta.

- Acho que você tem razão, Pedro. Mas, poderiamos verificar se sua explicação está correta lendo o assunto "poder das pontas" sugerido pelo Luiz Antônio - disse Patrícia. - Vamos agora para a biblioteca! nabiblioteca.

Naquele momento apenas ela poderia ir, então combinaram de se encontrar no dia seguinte às três horas da tarde

Levaram a experiência junto a eles. Todos que estavam lá acharam que era um truque de mágica. Tales, muito vaidoso, dizia que não era mágica e explicava os processos de eletrização que estavam ocorrendo.

Por sorte, Mário, um professor de Física, que estava na biblioteca, ajudou-os a entender o fenômeno chamado poder das pontas.

- Garotos! Quando eletrizamos um corpo que tem a forma de um círculo, as cargas tendem a se espalhar homogeneamente ao longo de sua superficie. No entanto, quando eletrizamos um corpo que possui uma forma que contém uma extremidade pontiaguda, tal como a gota de vocês, há uma concentração maior de cargas elétricas nas pontas. A explicação para este fenômeno provém do fato de que cargas de mesmo sinal repelem-se entre si. Como as cargas de mesmo sinal tedem a se espalhar ao máximo e a extremidade pontiaguda é a parte mais distante do resto do corpo, ocorre um acúmulo maior de cargas na ponta. Devido a este acúmulo de cargas, o campo elétrico é mais intenso do nas pontas, fato que explica o poder das pontas - concluiu o professor.

- Mas o que écampo elétrico? -estranhou Pedro.

- Existe um campo elétrico ou campo de forças elétricas em uma região do espaço se for colocado dentro dessa região uma carga e, ela ficar sujeita a forças elétricas, que podem ser de repulsão ou atração - explicou o professor como nos desenhos animados, onde algumas vezes o herói não consegue entrar em alguns lugares, por causa de uma força que age à distância. Para vocês entenderem melhor vamos fazer a seguinte brincadeira (Atividade 07): 


\section{CAMPO DE FORÇA}

\section{ATIVIDADE 10}

Você vai precisar de: 4 canudos de plástico, isopor, tesoura, um palito de fósforo, linha e papel higiênico.

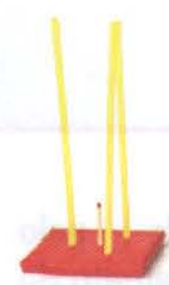

-Fixe no isopor três canudos eletrizados ao redor do palito de fósforo.

R

- Corte $20 \mathrm{~cm}$ de linha e amarre na sua extremidade um canudo. Em seguida atrite o canudo com papel higiênico. $\bar{E}$ importante lembrar que o canudo deverá ser eletrizado por inteiro. Depois corte o canudo, de forma que ele fique com $5 \mathrm{~cm}$ de comprimento aproximadamente.

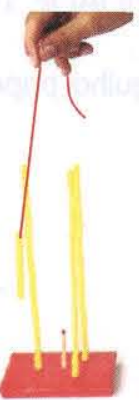

Agora tente acertar palito de fósforo com o canudo, que está preso na linha.

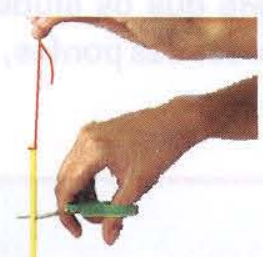

- Que legal! - disse Marcelo, tentando acertar o palito de fósforo. - Tem uma força que não deixa esse canudo encostarno palito.

Tales, muito engenhoso, eletrizou um canudo e depois picou-o em pedaços bem pequenos. Em seguida atirou os pedaços de canudo em direção do palito de fósforo, mas sua tentativa foi sem sucesso, porque os pedacinhos de canudos eletrizados desviavam quando aproximavam dos canudos fixos também eletrizados.
- Agora sim - disse Pedro - eu estou entendendo as palavras do professor, campo elétrico, ou melhor campo de força, afinal o que eu estou observando é o efeito da força.

- Isso mesmo garoto! - disse Mário. - Para não ficarnenhuma dúvida, darei um outro exemplo.

Suponha que haja uma carga positiva fixa. Se colocarmos algumas cargas negativas muito pequenas (a qual chamaremos de carga de prova), em vários pontos diferentes, ao redor da carga positiva, o que vocês esperam que aconteçam com as cargas de prova?

- Elas serão atraídas pela carga positiva, porque irão aparecer entre elas, como já sabemos pelas nossas experiências, as forças de atração respondeu Patrícia, fazendo alguns desenhos.
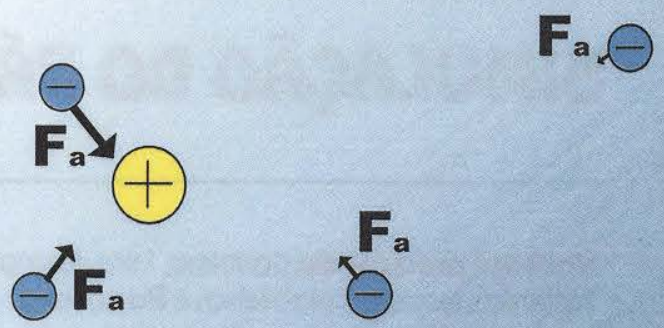

Eele prosseguia:

- O que aconteceria se as cargas de prova fossem positivas?

- É simples, surgiria uma força de repulsão entre elas - explicou Patrícia.

- Correto! - falou o professor. - Sempre que isto acontece, os físicos propuseram dizer que, existe um campo de forças na região do espaço onde a força se manifesta. No caso da força se originar em cargas elétricas o campo de força é denominado campo elétrico.

Garotos agora tenho que ir, mas quando precisarem de ajuda podem me procurar.

Como já era tarde, combinaram de se encontrar no outro dia na casa de Marcelo, para enviar e-mailao site. 
Logo que chegaram à casa de Marcelo, começou uma tempestade. Patrícia, que tinha medo de relâmpagos, perguntou se sabiam explicar como eles eram formados, apontando para um que estava caindo naquele momento.

- Patrícia, eu não sei - disse Marcelo - mas não fique com medo porque na casa do vizinho tem pára-raios, portanto toda essa região está protegida.

- Eu ficarei tranquila se você me explicar como o pára-raios nos protege! -avisou Patrícia.

- Ora veja!... - disse Marcelo tentando enrolar Patrícia.

- Vamos parar de enrolar - falou Pedro tentando colocar um fim naquela conversa-o melhor a fazeré enviar todas essas perguntas para o site do Luiz Antônio, já que não sabemos solucioná-las.

Eles acataram a sugestão de Pedro, e assim que a tempestade passou, cumpriram o combinado.

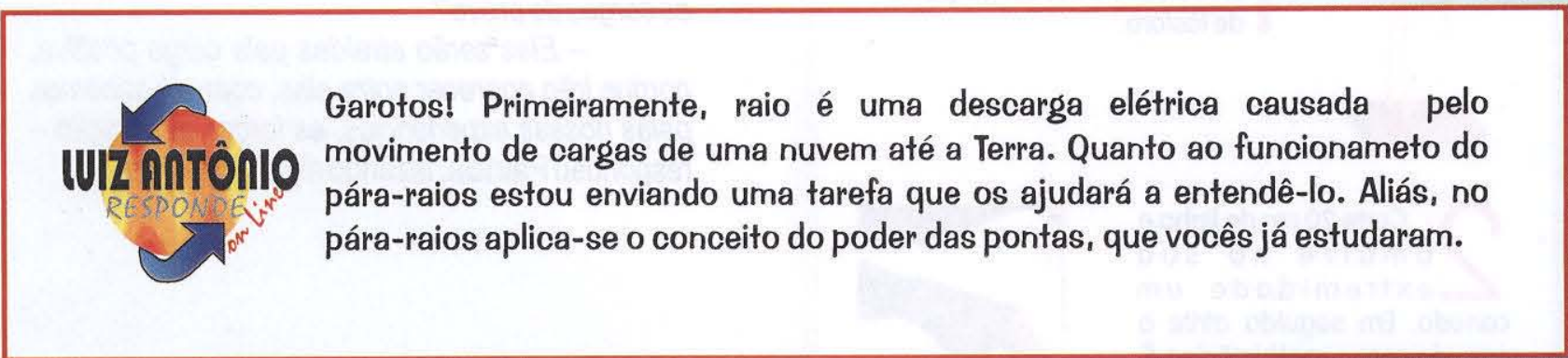

$-$

\section{SIMULAÇÃO DO PÁRA-RAIOS}

Você vai precisar de: Cartolina, 1 tira de papel de seda para balas, 2 canudos de plástico, isopor, agulha, papel higiênico, tesoura, cola branca e fita adesiva.

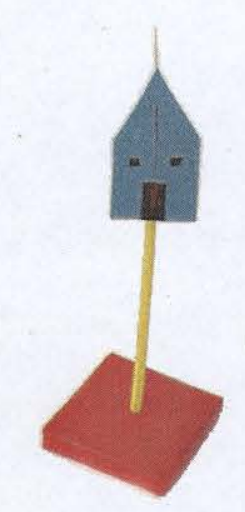

$$
1
$$

- Recorte uma cartolina (aproximadamente $8 \mathrm{~cm}$ de comprimento) na forma de uma igreja. Em seguida, cole a tira de papel de seda no meio da torre da igreja. Depois, com uma fita adesiva, pregue uma agulha na ponta da torre. Use um canudo como suporte para sustentar a igreja e pregue-o com a fita adesiva. Por último, fixe o canudo em um pedaço de isopor.

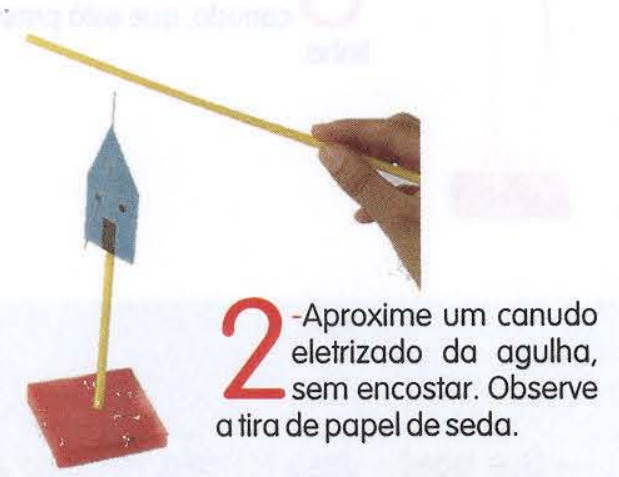

Coloque a ponta
do seu dedo na
igreja. E observe o que acontece com a tira.

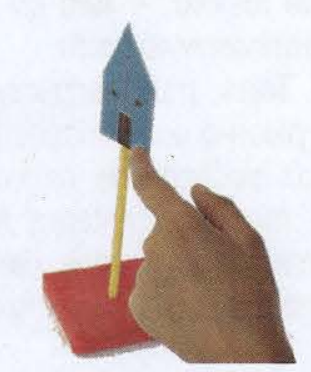


- Como é possivel! - disse Marcelo, indignado. - A tira permanece erguida mesmo depois de retirado o canudo, a igreja deve ter ficado eletrizada.

- Mas se não eletrizamos a igreja, por contato, nem por indução, nem por atrito, então como a igreja ficou eletrizada? - perguntou Patrícia.

- O interessante é - disse Pedro - que mesmo olhando bem de perto não vejo faísca saltando do canudo para a igreja.

- Eu também não escutei nada - falou Tales.

- É, infelizmente precisaremos procurar o Luiz Antônio para pedir ajuda - disse Marcelo, em frente ao computador esperando somente o consentimento dos colegas.

- Marcelo não perca tempo - disse Patrícia - envie nossas dúvidas para o site.

A resposta foi imediata.

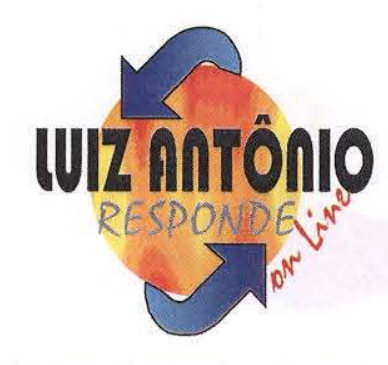

Garotos, quando vocês aproximaram o canudo eletrizado negativamente na ponta da agulha, uma grande quantidade de cargas positivas foram induzidas nela. Isto causou um campo elétrico intenso, no ar, entre a ponta $e$ o canudo.

Esse campo, por sua vez, ionizou o ar, isło é, provocou uma força suficiente para arrancar elétrons das moléculas constituintes do ar. Nessa situação, ele tornou-se condutor, propiciando a passagem de elétrons do canudo para a ponta da agulha. Por isso, a igreja e a tira ficaram carregadas negativamente. Como cargas iguais se repelem, a tira levantou-se.

0 pára-raios, que nos prołege de relâmpagos, também utiliza o poder das pontas. Ele é composto de uma ou mais pontas metálicas ligadas à terra por um fio de metal grosso que acaba em uma placa de cobre enterrada no solo. Ele deve ser colocado no ponto mais elevado do local a ser prołegido, como por exemplo: torres, prédios e igrejas.

Durante as tempestades as nuvens tornam-se carregadas negativamente ou positivamente. Faremos nosso estudo para uma nuvem carregada negativamente. Por onde ela passa, induz cargas positivas na Terra, criando um campo elétrico intenso entre a nuvem e a Terra. Como vocês viram na atividade "Simulação do pára-raios", isso possibilitará uma descarga elétrica (relâmpago), que dependendo da carga acumulada pode causar muitos acidentes fatais.

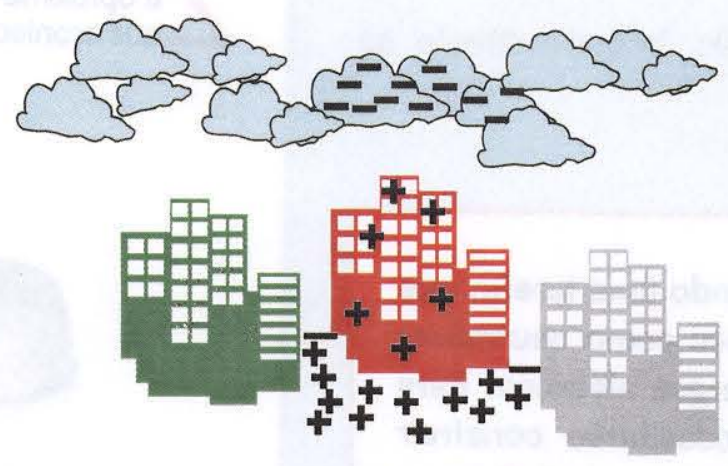

Caso o local tenha pára-raios, as cargas induzidas se acumularão nas suas pontas. Nesse caso o campo elétrico assim criado provoca ionização do ar nas suas proximidades permitindo a passagem das cargas que através dos fios apropriados transportarão eletricidade para o solo, quase sempre sem dano para o edifício.

Alerta: Devido ao poder das pontas, evite ficar de pé durante tempestades em locais abertos (pois você será a própria ponta) ou próximo a objełos pontiagudos, como árvores ou postes. 


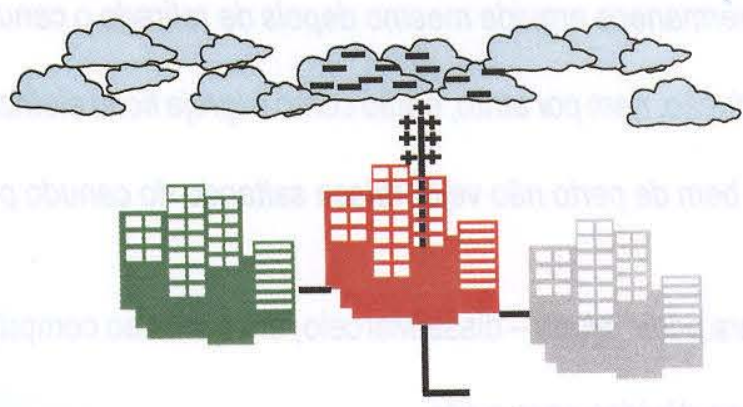

0 inventor desse aparelho, que impede muitas catástrofes, foi Benjamin Franklin em meados de 1750.

A região de prołeção do pára-raios é um círculo em torno do edifício de diâmetro aproximadamente igual a cinco vezes a altura do edificio.

- Mas o site não explicou o que é trovão - disse Tales, desapontado, após ler o e-mail.

- É verdade - falou Patrícia, pegando um livro de física. Quem sabe não encontramos a resposta para sua dúvida aqui. Não falei, aqui está: "Trovão resulta da rápida expansão do ar, aquecido pelo calor produzido pelo raio".

- Ora vejam só! - exclamou Marcelo, assim que Patrícia terminou sua leitura. - 0 nosso dedo tem a mesma função do fio metálico ligado à Terra no pára-raios, serve para conduzir as cargas elétricas. Isso significa que o pára-raios neutraliza as nuvens?

- Não - disse Pedro. - O pára-raios oferece ao raio um caminho fácil até o solo que é ao mesmo tempo seguro para nós e para o que pretendemos proteger. Mas podemos escrever para o site perguntando como podemos neutralizar o efeito produzido pela carga.

- Pois vamos - falou Marcelo, indo em direção ao computador.

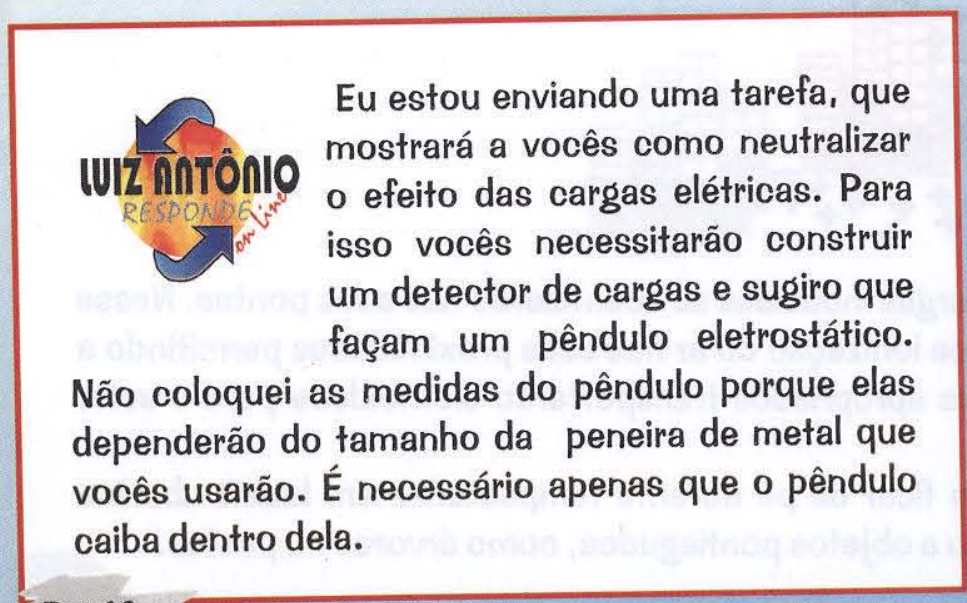

Pą.18

\section{SIMULAÇÃO DA GAIOLA DE FARADAY}

ATIVIDADE 12

Você vai precisar de: 2 canudos de plástico sanfonado, linha, folha de aluminio, papel higiênico, isopor, fita adesiva, tesoura e 1 peneira de metal.

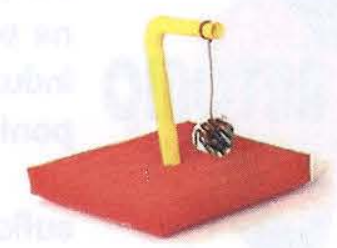

7 - Dobre um canudo de modo que ele forme um $L$ e fixe-o no isopor. Amarre uma linha na extremidade do canudo e, em seguida, cole com fita adesiva um disco de folha de alumínio na ponta da linha.

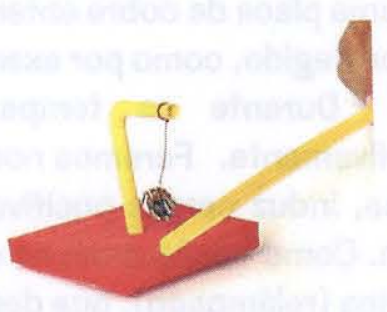

2

Atrite um canudo com papel higiênico aproxime-o do disco de alumínio. 0 que acontece com o disco.

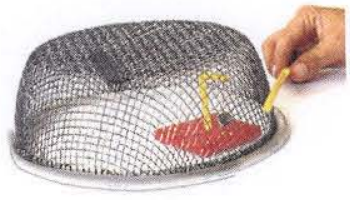

- Agora coloque a peneira de metal em cima do pêndulo. Em seguida aproxime o canudo eletrizado nela. $O$ que acontece com o disco. 
- Nossa Senhora! Isso parece mágica! - exclamou Tales, fazendo uma demonstração. - Vou aproximar o canudo eletrizado do pêndulo, viu como ele mexe. Agora colocarei a peneira de metal em cima dele, e em seguida aproximarei o canudo eletrizado, percebam que nada acontece com o pêndulo, ele nem se move, porquê?

- Estamos tão surpresos quanto você - disse Pedro - e também não sabemos explicar porque isso acontece. Vamos escrever para o Luiz Antônio falando que fizemos tudo como ele tinha proposto e que percebemos que a peneira bloqueia o efeito do canudo eletrizado sobre o pêndulo, mas não sabemos qual o motivo.

Tanto concordaram com Pedro que foram para o computador naquele instante, redigir o e-mail.

A resposta foi imediata.

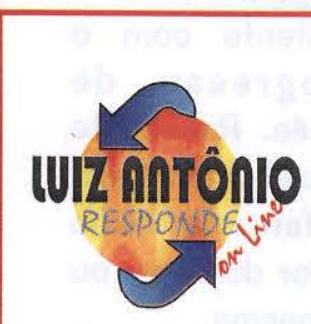

Garotos, sugiro $q u$ e procurem nos livros de física o assunto o título "Blindagem Eletrostática". Isso os ajudará a entender qual é o papel da peneira. Mas, antes peço que executem uma outra tarefa, talvez ela esclareça ainda mais suas dúvidas.

\section{Proteção contra carda elétrica}

Você vai precisar de: Cartolina, 2 tiras de papel de seda para balas, 2 canudos de plástico, isopor, papel higiênico, tesoura, cola branca e fita adesiva.

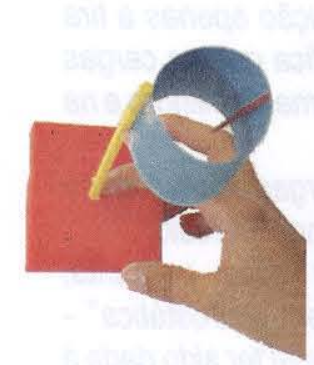

cartolina na forma de um retângulo $(7 \times 15) \mathrm{cm}$. Cole duas tiras de papel de seda uma em cada face do retângulo. Em seguida, cole as extremidades do retângulo na forma de um cilindro. Como suporte para o cilindro utilize um canudo. Fixe o canudo em um pedaço de isopor.

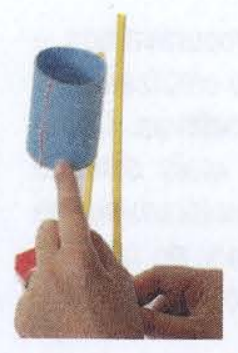

Retire o dedo e depois o canudo. Observe o que acontece com as tiras de papel de seda.

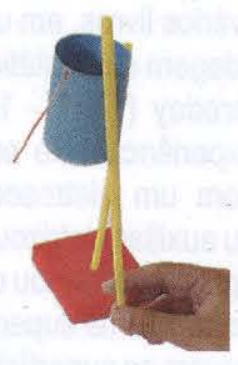

3 - Mantendo o canudo na sua posição, encoste a ponta do dedo por fora no cilindro.

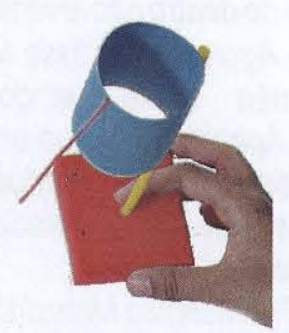


- Isso é um espanto! - disse Pedro, depois que eletrizou o cilindro. - Conseguimos fazer uma superfície ficar eletrizada e a outra neutra, afinal a tira de fora do cilindro foi repelida e a de dentro ficou caida sobre a cartolina.

- Alto lá! A tira de dentro não levantou porque você eletrizou o cilindro por fora - falou Tales, duvidando de Pedro. - Tenho certeza se nós colocarmos o canudo eletrizado dentro do cilindro as duas tiras ficarão erguidas.

- Não devemos ficar com nenhuma dúvida - disse Pedro - vamos colocar o canudo dentro do cilindro e ver o que acontece.

Atritaram o canudo com papel higiênico e depois colocaram-no dentro do cilindro.

- Tenho que concordar, eu estava errado! reconheceu Tales. - Porque mesmo colocando o canudo dentro do cilindro e eletrizando-o por indução apenas a tira que está presa fora se levanta. Isso significa que as cargas em excesso estão todas na superfície externa do cilindro e na tira externa também.

- A questão agora é, por que as cargas acumulam-se na superfície externa do cilindro? - questionou Marcelo.

- Acredito que para responder essa pergunta, precisaremos descobrir o que é "Blindagem eletrostática" falou Pedro. - Afinal essa sugestão não deve ter sido dada à toa pelo Luiz Antônio.

Pedro, fascinado com as descobertas, havia comprado vários livros, em um deles existia uma explicação sobre "Blindagem eletrostática" cujo conteúdo versava sobre Michael Faraday (1791 - 1867) um físico, que realizou a seguinte experiência: ele entrou no interior de uma gaiola metálica com um eletroscópio de folhas nas mãos. Em seguida seu auxiliar eletrizou a gaiola. Faraday nada sofreu e o eletroscópio não detectou cargas. Com isso, ele comprovou que no interior de uma superfície metálica não havia cargas e que elas ficavam na superfície externa.

- Pessoal! Aqui está a resposta que procurávamos. afirmou Pedro, com o livro na mão. - Quando eletrizamos o cilindro, ele ficou com excesso de cargas positivas. Como cargas iguais se repelem, elas ficaram o mais distante possivel umas das outras, por isso acumularam-se na superfície externa Não tendo carga no interior do cilindro, conseqüentemente não haverá força ou campo elétrico, e por isso a tira de dentronão levantou.

- Agora sim - disse Marcelo - eu entendi porque o pêndulo não mexe quando está no interior da peneira metálica. Aproveitando que estamos falando nisso, eu tenho uma dúvida que vem me intrigando há muito tempo e acredito que a resposta esteja relacionada com os conceitos que acabamos de discutir.

Eprosseguiu Marcelo:

- Eu já reparei que o rádio do carro do meu pai não funciona quando a antena não está erguida. Alguém sabe responderporquê?
- Isso é um caso curioso! - disse Pedro coçando a cabeça. - Mas nós podemos comprovar se isso é verdade, simulando uma situação parecida com a do rádio dentro do carro sem antena. Primeiro nós vamos colocar um rádio de pilha ligado dentro de uma panela e depois tampá-la. Será que continuaremos a ouvir orádio?

Marcelo pegou o rádio de pilha que o pai usava para ouvir o futebol e uma panela de sua mãe. Primeiro sintonizaram uma estação de rádio e aumentaram o volume, de modo que desse para ouvir quando o aparelho estivesse dentro da panela, mas quando colocaram 0 rádio ligado dentro da panela $e$ tamparam-na, não conseguiram ouví-lo

-Isso é inacreditável! Não é possível ouvir o rádio quando tampamos a panela. Por quê, Pedro? perguntou Tales.

- Era o que eu esperava mas, infelizmente, eu não sei explicar!!! - disse Pedro. - Vamos escrever para o Luiz Antônio contando o que fizemos e depois pedimos uma explicação.

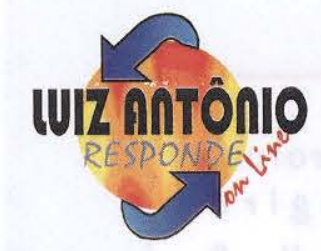

Estou muito contente com o progresso de vocês. Realmente a explicação para - fato do rádio não funcionar no interior do carro ou da panela tampada é a mesma.

Para sintonizar uma estação de rádio é necessário que a antena receba da estação transmissora uma onda de rádio que contenha todas as informações, como a música e a voz do locutor. Vocês devem estar se perguntando o que é uma onda de rádio? Agora é suficiente que saibam que uma onda de rádio é composta por campo elétrico.

Pā๕.20 
Como em ambos os casos o rádio encontra-se dentro de uma superficie condutora fechada a onda de rádio, não consegue atingí-lo, porque o campo elétrico no interior da panela e do carro é zero, fato comprovado na atividade 12. Em suas aulas de física certamente você aprenderá melhor estas idéias.

- Eu tenho que confessar a vocês - disse Pedro, após ler o e-mail - estou cada dia mais fascinado pela ciência.

- Pedro! Todos nós estamos encantados. - falou Patrícia, sorrindo.

- Eu estive pensando sobre nossas descobertascomentou Tales. - Será que tudo isso serve apenas para mágica?

- Bom! Eu sei que todos esses conceitos são ensinados na escola-Pedro completou logo em seguida.

- Ah! Eu duvido que tudo isso não tenha uma aplicação - avisou Patrícia. - Vamos escrever para o Luiz Antônio contando nossas dúvidas, pois tenho certeza que ele poderá nos ajudar.

Ea resposta veio imediatamente.

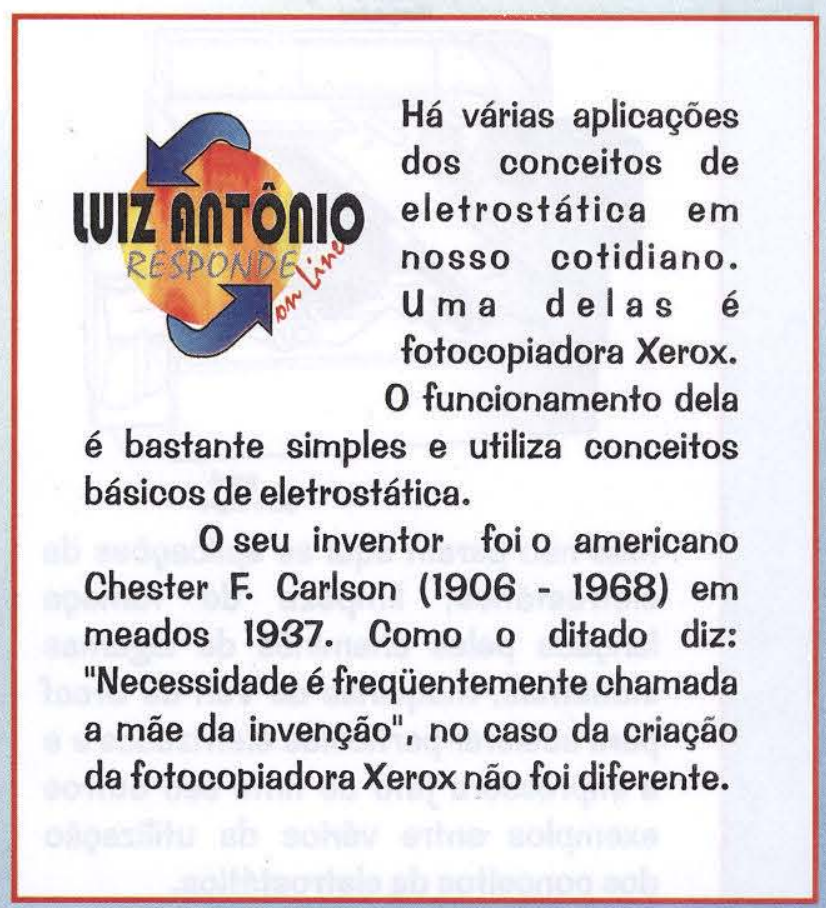

Carlson, na juventude, trabalhava em um escritório de patentes, mas o trabalho exigia que ele fizesse várias cópias de um mesmo documento. Para facilitar o seu trabalho, dedicou-se a criar uma máquina que fizesse cópias. Depois de intensas pesquisas, ele descobriu que existiam materiais que mudavam suas propriedades elétricas quando expostos à luz e deduziu que esses materiais poderiam ser utilizados para a construção da sua máquina.

Para melhorar o entendimento de vocês, estou lhes enviando ilustrações que mostram os processos da fotocopiadora Xerox proposta por Carlson.

Atenção: Não tentem reproduzir os procedimentos citados abaixo, porque o enxofre é prejudicial à saúde.

1) Primeiro ele cobriu com enxofre (material fotocondutor, que é bom isolante no escuro $e$, comporta-se como condutor quando exposto à luz) uma placa de zinco.

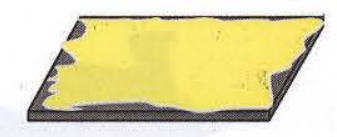

2) Depois Carlson, no escuro, eletrizou com cargas positivas o enxofre. Essas cargas, por sua vez, distribuíram-se uniformemente pela superficie do enxofre.

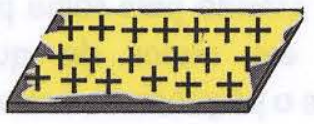


3) Em seguida, ele pegou uma folha que tinha impressa "10-22-38" e projetou uma luz sobre ela, de modo que a imagem fosse refletida na placa de zinco coberta com enxofre.

A imagem "10-22-38", formou no enxofre áreas escuras nas regiões das letras, mantendo nesses locais as cargas positivas, porque no escuro ele comporta-se como isolante. Já nas áreas iluminadas, ele comporta-se como condutor, portanto, as cargas positivas contidas no enxofre, adquiriram mobilidade, atraindo as cargas negativas do zinco e, neutralizaram-se.

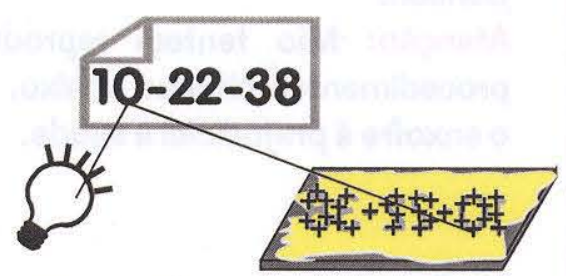

4) Ele, então, jogou um pó preto eletrizado negativamente sobre o enxofre. Esse pó, por sua vez, foi atraído para as regióes que esłavam eletrizadas positivamente.

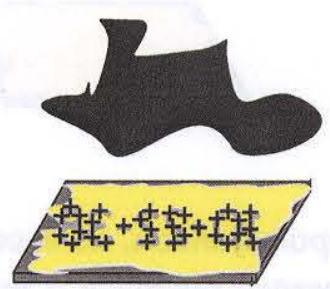

5) Enquanto isso Carlson eletrizou uma folha em branco, com um número maior de cargas positivas do que as contidas no enxofre. Todo o pó foi atraído pela folha porque a força de atração era maior do que a força que mantinha o pó preso no enxofre.

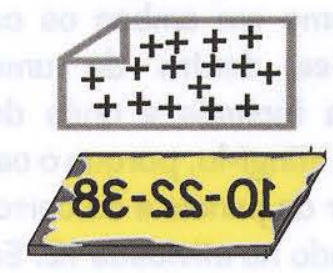

6) Para o pó aderir nas fibras de papel, o conjunto pó e o papel passam por cilindros quentes.

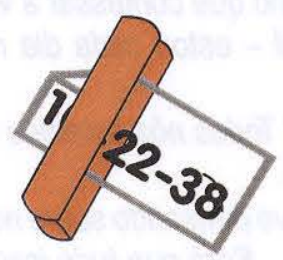

A fotocopiadora Xerox que usamos hoje é bem parecida com a descrita acima, apenas com algumas modificações. Usa-se selênio no lugar do enxofre, porque ele é mais eficaz no processo da fotocondutividade. Trocou-se a placa por um cilindro e o pó preto usado é o toner.

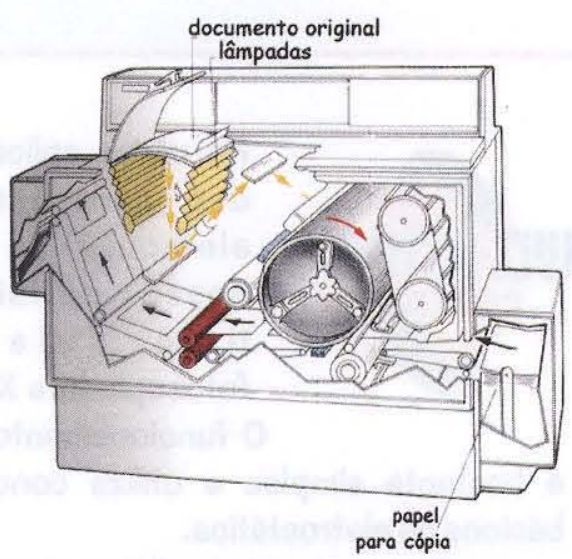

Mas não param aqui as aplicações da eletrostática; limpeza de fumaça lançada pelas chaminés de algumas indústrias, máquinas de Van de Graaf para acelerar partículas eletrizadas e a a impressora jało de tinta são outros exemplos entre vários da utilização dos conceitos da eletrostática. 
As férias escolares de julho haviam chegado e cada um iria viajar com suas famílias por um mês.

Na última reunião antes de viajarem a mãe de Marcelo preparou um lanche especial. A algazarra foi total. Enquanto conversavam, o quarto onde estavam escureceu. Pedro, instantaneamente foi conferir se havia acabado a energia ou se a lâmpada tinha queimado. $E$, descobriu que a lâmpada havia queimado. Como naquele momento não tinha ninguém em casa, terminaram a reunião sob a luz de uma lanterna.

Pedro, insatisfeito com aquela situação, questionou os colegas.

- Existe uma relação entre os conceitos aprendidos nas experiências e a eletricidade responsável por manter as lâmpadas acesas? Pensemos nisso! 


\section{Lista de materiais}

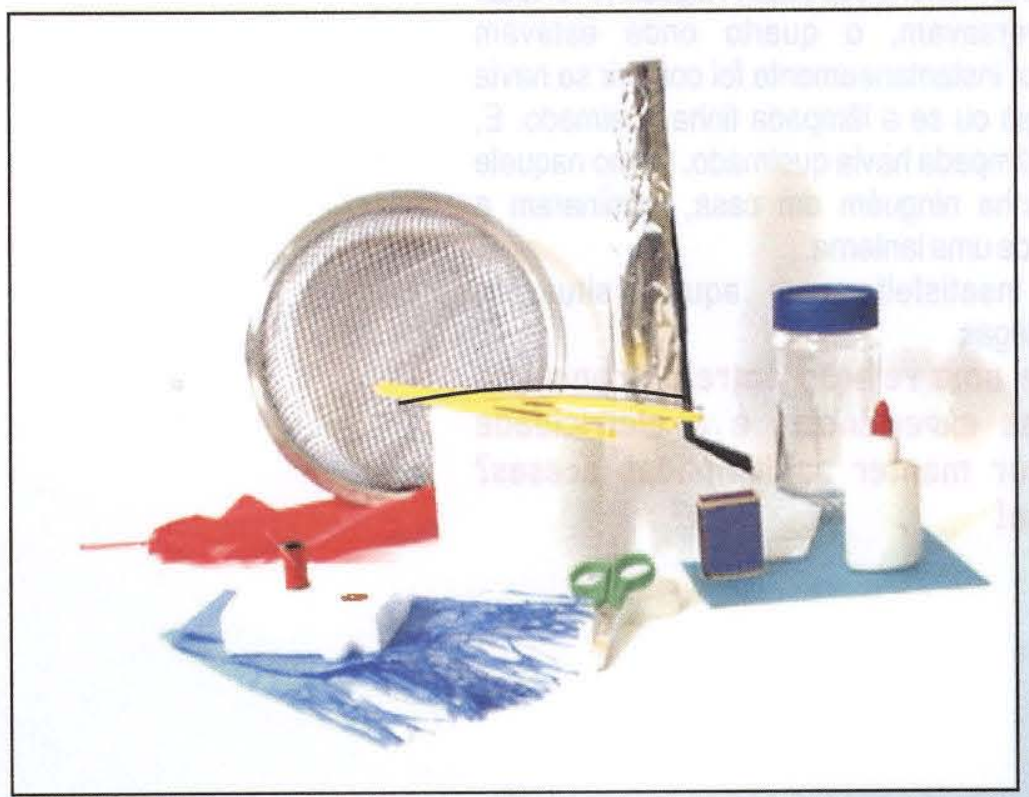

Na foto acima estão todos materiais necessários para a realização das atividades propostas nesse fascículo. Primeiramente faremos algumas recomendações quanto ao uso deles e, quando possivel sugeriremos outros materiais.

I - Os canudos plásticos são os usados para tomar refrigerante. Devo ressaltar que eles não podem ter sido usados anteriormente. Quanto aos canudos sanfonados são necessários apenas na construção do pêndulo eletrostático, mas isso não impede que você os use em todas as atividades. A cor é outro fator que infuencia na eletrização, por isso não desista caso esteja tendo dificuldade para eletrizá-lo..

2- Os canudos deverão ser atritados da seguinte forma: passe o papel higiênico sempre na mesmo sentido e com força. Evite usar o mesmo pedaço de papel higiênico ao eletrizar um objeto.

3-É recomendável papel higiênico macio e de preferência retirado recentemente da embalagem. Ele poderá ser trocado por uma flanela limpa e seca ou melhor ainda um retalho de tecido de lã puro ou mesmo uma pele de animal peludo (até nosso cabelo).

4- As tiras de papel de seda recomendadas em várias atividades podem ser retiradas das franjas de papel usado para embrulhar balas de aniversário. Cuidado, pois a experiência poderá fracassar se o papel estiver úmido ou engordurado.

5- O vidro usado na construção do eletroscópio de folhas, poderá ser qualquer recipiente transparente e descartável. Cuidado com a umidade do ar pois o vapor d'água costuma se depositar sobre o vidro em gotículas invisiveis.

6- A linha utilizada em todas as atividades deve ser leve. 
As Aventuras de Pedro 


\section{Caro Leitor}

A motivação desse trabalho é fornecer um material que estimule você, leitor, a conhecer os fascínios da ciência. Para isso, estamos apresentando, com naturalidade, por intermédio de experimentos simples, inseridos numa narrativa ficcional, alguns conceiłos complicados, sempre que possivel associando-os ao cotidiano.

Esse livro é recomendado tanto para leigos a partir de 12 anos quanto para profissionais da área. Queremos deixar claro que a leitura do mesmo não dispensa o acompanhamento de um livro didático para um aprendizado mais profundo.

o conteúdo do livro é apresentado por meio de questionamentos que os personagens fazem entre si e, quando não conseguem resolvê-los por si só, procuram um site, que conduzirá toda a história, sempre respondendo o necessário e propondo atividades com as quais serão esclarecidas todas as dúvidas. A história da eletricidade é apresentada no decorrer do texto pelos próprios personagens. Todos os experimentos propostos utilizam materiais simples e de baixo custo que foram rigorosamente testados afim de estimular o interesse do leitor pela ciência.

Para um melhor aproveitamento do conteúdo do livro é recomendado que as atividades sejam efetuadas na ordem que são sugeridas.

Utilizamos a figura $\approx$ para simbolizar que os experimentos necessitam da presença de um adulto, pois são atividades que podem trazer danos à integridade física do leitor. Já o símbolo 命 página onde são feitas recomendações sobre os materiais utilizados nas experiências e quando possível a subtituição dos mesmos.

Nesse fascículo você construirá uma pilha, aprenderá como são ligadas as lâmpadas dos postes nas ruas, entre outros fenômenos. Por isso, convidamos você, caro leitor , a viajar por esse mundo da eletricidade.

Vamos??? 


\section{As aventuras de Pedro}

Depois de um mês em férias, lá estavam Marcelo, Pedro Patrícia e Tales novamente reunidos. 0 entusiasmo pelo retorno era unânime. Todos queriam falar ao mesmo tempo, mas Pedro logo conseguiu a atenção dos colegas, porque tinha histórias intrigantes para contar, aprendidas em um museu de ciências em São Carlos, Centro de Divulgação Cientifica e Cultural (CDCC), onde passou a maior parte de seu tempo.

- Vocês precisam conhecer o museu de ciências, é muito legal! Lá tinha uma máquina elétrica, chamada Gerador de Van de Graaff, esse aparelho armazena cargas elétricas em uma esfera e, quando encostávamos a mão nela, o cabelo ficava todo arrepiado. Haviam monitores que esclareciam todas as dúvidas... - Pedro, muito empolgado, continuava:

- Aproveitando que estamos falando nisso, vocês lembram o que eu disse na última vez que nos encontramos? - perguntou ele.

- Lógico que não - falou Tales, com um tom de indignação.

- Está bem, irei repetir a pergunta que eu fiz - disse Pedro. "Existe uma relação entre os conceitos aprendidos nas experiências de eletrostática e a eletricidade responsável por manter as lâmpadas acesas?".

E sem esperar a resposta dos colegas continuou:

- Eu trouxe a solução para essa questão, mas prefiro não dizer nada. Façam tudo que está escrito nesse papel e depois nós conversamos (Atividade 01).

\section{ACENDA UMA LÂMPADA COM CANUDOS}

\section{Atividade 01}

Você vai precisar de: 1 lâmpada fluorescente, 4 canudos plásticose papel higiênico.
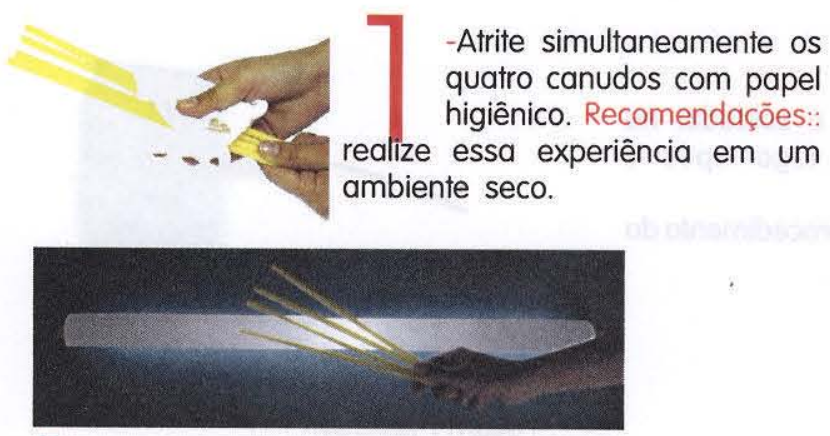

Encoste os canudos eletrizados na âmpada fluorescente, em várias posiçōes. Observe o brilho da lâmpada.
Perigo: É necessário muito cuidado com a lâmpada para não deixá-la quebrar. Porque as substâncias no seu interior são prejudiciais à saúde.

No começo não conseguiram perceber o brilho da lâmpada. Tiveram então a idéia de escurecer o quarto, e viram que ela emitia luz de baixa intensidade.

- Isso é incrivel! - exclamou Tales, naquela escuridão.

- Pedro, por que esfregar os canudos com papel higiênico? -questionou Marcelo.

- Quando esfregamos os canudos com papel higiênico, alguns elétrons escaparam do papel e passaram para os canudos. Eles, então, ficaram com excesso de cargas negativas (elétrons), ou seja, eletrizados negativamente - explicou Pedro, repetindo o que tinha aprendido na leitura de um livro.

प⿺辶寸) Maiores detalhes podem ser encontrados no livro "O enigma de Tales de Mileto".

- Pedro, você poderia explicar porque os canudos eletrizados acenderam a lâmpada? - perguntou Patrícia. - Mas antes fale o que tem dentro da lâmpada fluorescente!

- A lâmpada fluorescente é preenchida com vapor de mercúrio, e a superfície interna do vidro é revestida com um pó branco chamado "fósforo" - disse Pedro, pegando papel e caneta, para explicar fazendo desenhos. - Esse pó tem a característica de transformar raios ultravioleta em luz visivel.

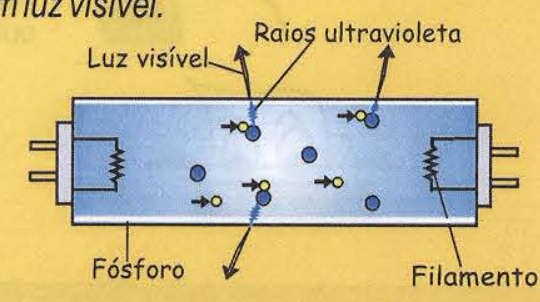

- Elétron o Átomo de mercúrio

Páq.01 
Periqo! É necessário muito cuidado com o soldador, quando em contato com a pele ele poderá causar queimaduras graves porque sua temperatura chega a $300^{\circ} \mathrm{C}$. Para maior segurança, peça à uma pessoa adulta para soldar os cabinhos nas garras.

- Agora com esses materiais podemos construir a nossa pilha-disse Pedro.

\section{PILHA}

Atividade 03

Você vai precisar de: 2 chapas de cobre e 2 chapas de zinco de $8 \mathrm{~cm}$ de comprimento e $2 \mathrm{~cm}$ de largura, 2 copos de plástico de $180 \mathrm{ml}$, 1 led (vermelho), vinagre, 3 jacarés.

- Coloque uma chapa de zinco e uma de cobre em cada copo. Em seguida, encha-os com vinagre.

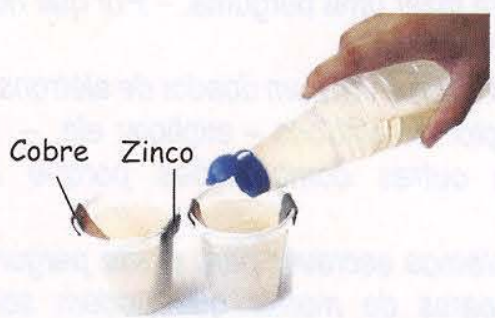

2

- Ligue uma chapa de zinco e uma cobre, com o jacaré.

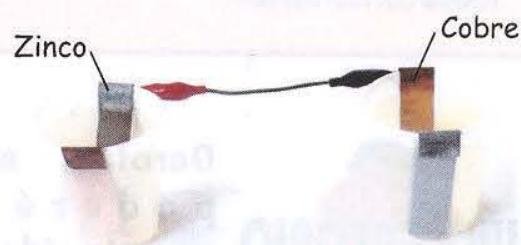

3

- Ligue em série uma chapa de zinco, 1 led e uma chapa de cobre, com os jacarés, como mostra a foto. Observe oled.

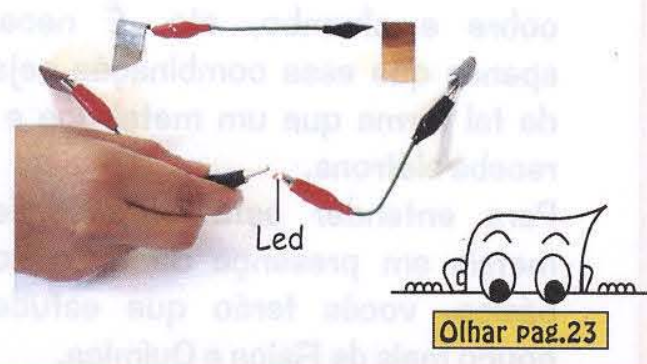

- O que é um led? Por que não usar uma lâmpada? - perguntou Tales, enquanto estavam montando a pilha.

- Eu não sei - respondeu Pedro. - Mas podemos enviar essas dúvidas via e-mail para 0 site de física "Luiz Antônio Responde".

- Venham ver a pilha! - gritou Marcelo. O que aconteceu? Porque oled não acendeu?

- Muito curioso! Afinal essa montagem está igual a pilha que vi no museu - comentou Pedro. - Vamos mudar a posição do led, colocaremos a ponta maior presa na placa de cobre e a ponta menorna placa de zinco.

- Agora sim, mas você é um garoto esperto!-brincou Marcelo.

- Por que a ponta maior do led tem que ser conectada na placa de cobre e a menor na placa de zinco? - perguntou Patrícia.

- Não sei, foi só um palpite que deu certo - disse Pedro, sorrindo.

Ficaram um bom tempo, apreciando a nova descoberta. Trocaram o vinagre por cocacola e depois por limão e, para a surpresa deles, 0 led acendeu com todas estas soluções. Após passar o encantamento escreveram as perguntas de Tales e a dúvida de Patrícia ao site.

A resposta via e-mail foi imediata.

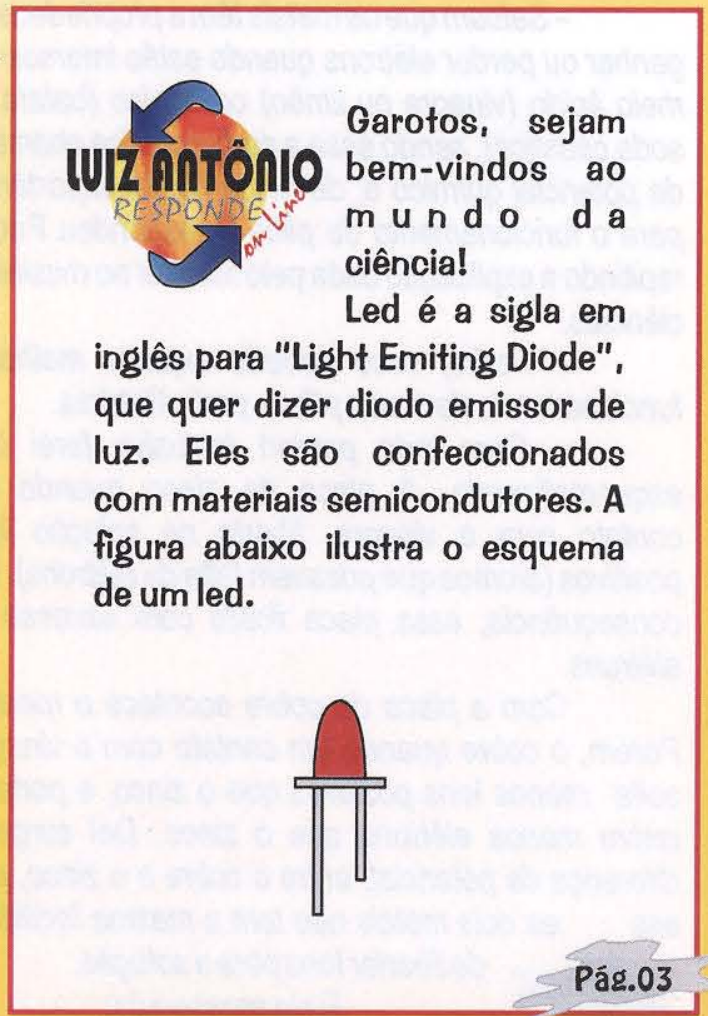




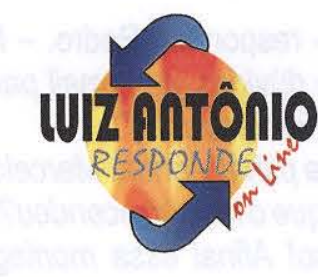

A ponta maior,

t a m b é $m$

chamada de cátodo, deverá ser ligada à placa de cobre (pólo positivo)

e a ponta menor chamada anodo à placa de zinco (pólo negativo). Isso deve-se ao fato do led conduzir corrente elétrica apenas em um sentido.

É vantajoso usar o led porque ele transforma em luz quase toda energia elétrica fornecida pela pilha, diferentemente da lâmpada incandescente que perde energia em forma de calor.

- Lendo a resposta encontrada no site, surgiu uma outra dúvida - falou Patrícia. - Vocês sabem explicar porque o led acendeu quando as placas foram colocadas dentro do copo com vinagre?

- Saibam que os metais têm a propriedade de ganhar ou perder elétrons quando estão imersos em meio ácido (vinagre ou limão) ou básico (batata ou soda cáustica), sendo essa a característica chamada de potencial químico e, de fundamental importância para o funcionamento da pilha - respondeu Pedro, repitindo a explicação dada pelo monitor no museu de ciências.

- Pedro, você poderia explicar melhor o funcionamento da nossa pilha-pediu Patrícia.

- Com todo prazer! Inclusive farei isso esquematizando. A placa de zinco quando em contato com o vinagre, liberta na solução íons positivos (átomos que possuem falta de elétrons). Por consequência, essa placa ficará com excesso de elétrons.

Com a placa de cobre acontece o mesmo. Porém, o cobre quando em contato com o vinagre, solta menos ions positivos que o zinco, e portanto retém menos elétrons que o zinco. Dai surge, a diferença de potencial, entre o cobre e o zinco, pois ess es dois metais não tem a mesma facilidade Páq.04 de libertaríons para a solução.

Páq.04 Eele prosseguia:

Como nesta situação, o zinco possui mais elétrons livres acumulados em suas superficies que o cobre, quando ambos estão imersos em meio ácido (vinagre), ocorre um fluxo de elétrons da placa de zinco para a placa de cobre através do fio condutor ligado a elas, mas antes de atingí-la, os elétrons passaram pelo led fazendo com que o mesmo acenda.

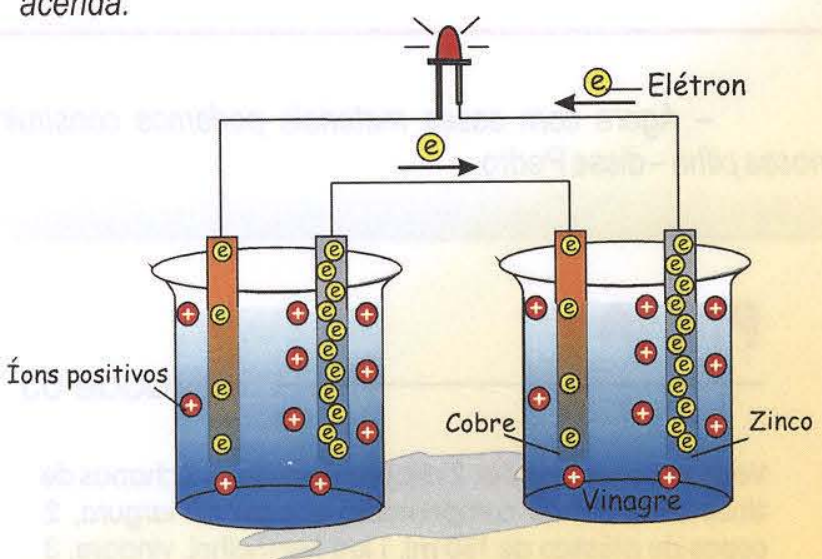

Esses processos se repetirão até que 0 zinco e 0 cobre se oxidem, isto é, cria-se uma camada isolante sobre as placas.

- Pedro, agora eu posso falar? - perguntou Patrícia, ansiosa para fazer uma pergunta. - Por que nós usamos os metais cobre e zinco?

- O zinco é um bom doador de elétrons e o cobre um ótimo receptor de elétrons - explicou ele. - Mas não me perguntem outras combinações porque não saberei responder.

- Vamos escrever para o site perguntando outros possiveis pares de metais que podem ser usados na construção da pilha - sugeriu Marcelo, em frente ao computador.

Todos concordaram.

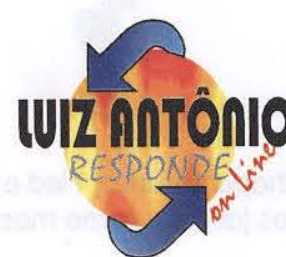

Garotos, a pilha poderá ser construída com vários pares de metais, por exemplo: cobre e alumínio, cobre e chumbo, ełc. É necessário apenas que essa combinação seja feiła de tal forma que um metal doe e outro receba elétrons.

Para entender esta propriedade dos metais em presença de meio ácido e básico, vocês terão que estudar um pouco mais de Física e Química. 
Para cada par de metais diferentes estabelece-se uma diferença de potencial. Por exemplo, em uma pilha constituída com uma placa de cobre e outra de zinco a diferença de potencial é 1,1V. No entanto, se as placas forem de cobre e de alumínio, a diferença de potencial é $0,5 \mathrm{~V}$.

Uma outra informação importante é que na pilha ocorre uma transformação de energia química em energia elétrica. Essa energia elétrica pode ser medida através da diferença de potencial. Para entender melhor o que é diferença de połencial ou tensão, podemos utilizar garrafas, que contenham água, ligadas por uma mangueira. Usando essa analogia, estou propondo uma atividade bem simples, na qual a água representará o fluxo de elétrons, a mangueira o fio e as garrafas as placas de zinco e de cobre, a fim de esclarecer qualquer dúvida sobre diferença de potencial.

\section{DIFERENÇA DE POTENCIAL}

Você vai precisar de: 2 garrafas plásticas de refrigerante de $2 \mathrm{~L}, 50 \mathrm{~cm}$ de mangueira de $1 \mathrm{~cm}$ de diâmetro, 2 torneiras para filtro, estilete, lâmina de serra, tesoura e água com corante (suco de laranja).

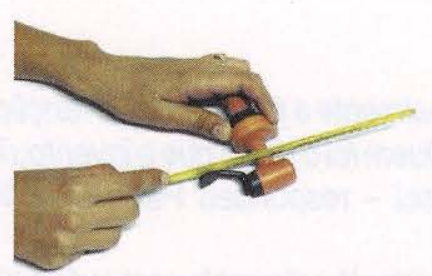

- Corte o bico da torneira com a lâmina de serra. Tenham muito cuidado com a lâmina de serra.
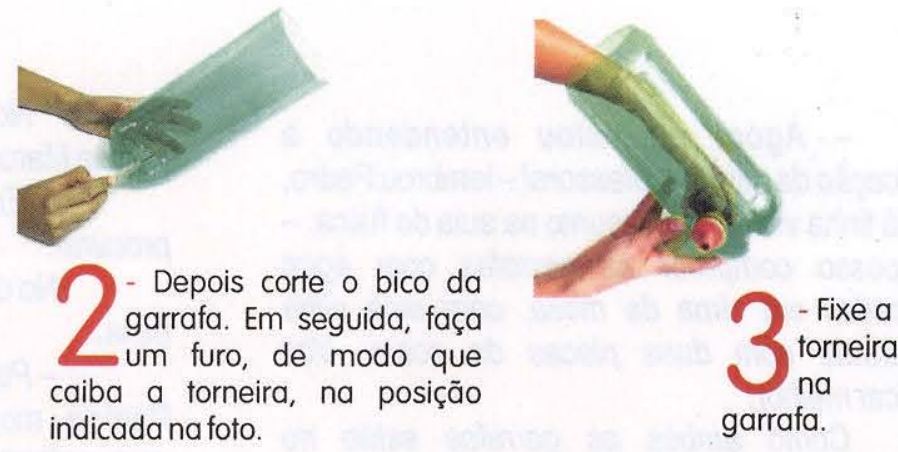

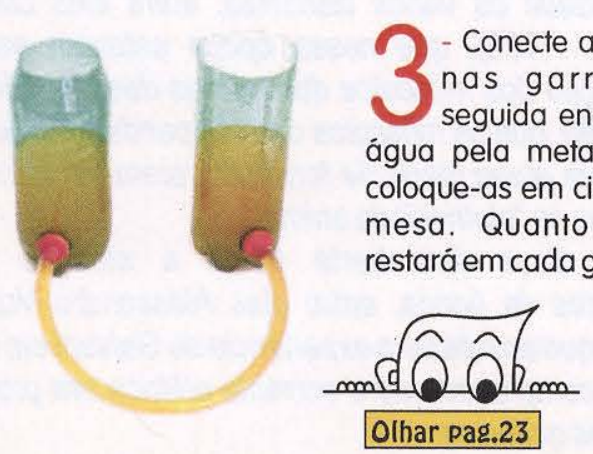

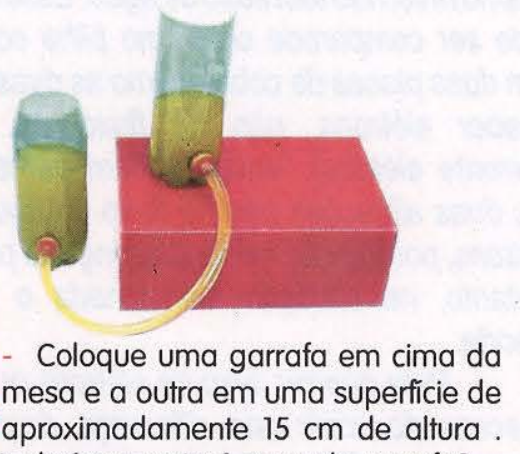
Quanto de água restará em cadagarrafa? 
Durante todo tempo, Patrícia esteve a observar a atividade e na primeira oportunidade explicou o que estava ocorrendo com desenhos.

- Colocando as duas garrafas, preenchidas com água pela metade, em cima da mesa, percebemos que o fluxo de água é nulo dizia Patrícia, imitando uma professora.

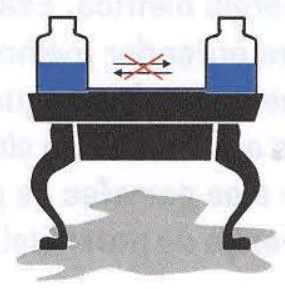

- Porém, quando colocamos as garrafas em níveis diferentes, a água da garrafa que está mais alta será transferida para a que está mais baixa.

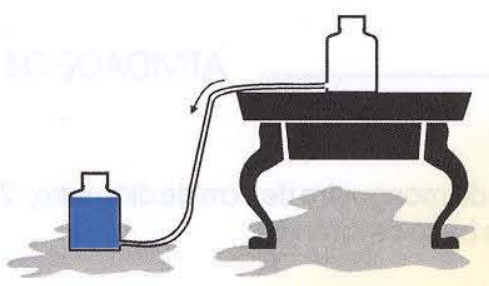

- Agora eu estou entendendo a explicação da minha professora! - lembrou Pedro, que já tinha visto esse assunto na aula de física. Eu posso comparar as garrafas com água colocadas em cima da mesa, com uma pilha construida com duas placas de cobre. Vou explicarmelhor:

Como ambas as garrafas estão no mesmo nível não tem fluxo de água. Essa situação pode ser comparada com uma pilha construída com duas placas de cobre, como as duas querem receber elétrons, não há fluxo de elétrons (corrente elétrica). Vocês podem perceber que nas duas situações não há fluxo de água ou de elétrons, porque não existe diferença de potencial. Portanto, na situação mencionada o led não acende.

Para ocorrer fluxo de elétrons ou cargas, é necessário existir uma diferença de potencial, por isso as pilhas são construídas com bons doadores e receptores de elétrons.
- Com as garrafas - falou Tales - eu entendi que a altura é responsável pelo fluxo de água, mas no caso da pilha eu não estou entendendo o que produz a corrente elétrica.

- Pedro, isso eu posso explicar - avisou Patrícia, querendo mostrar o que havia aprendido em suas leituras. $\mathrm{Na}$ pilha ocorrem reações químicas que provocam uma separação de cargas, tornando a placa de zinco carregada negativamente e a placa de cobre também carregada negativamente, mas com menor quantidade de elétrons. $A$ consequência é que o zinco fica com o potencial mais alto que o cobre, como uma das placas está mais negativa, surge uma diferença de potencial entre eles. Essa diferença de potencial, por sua vez, provocará uma força elétrica sobre cada elétron livre presente no fio que está conectado a ela, fazendo com que eles circulem, gerando a corrente elétrica.

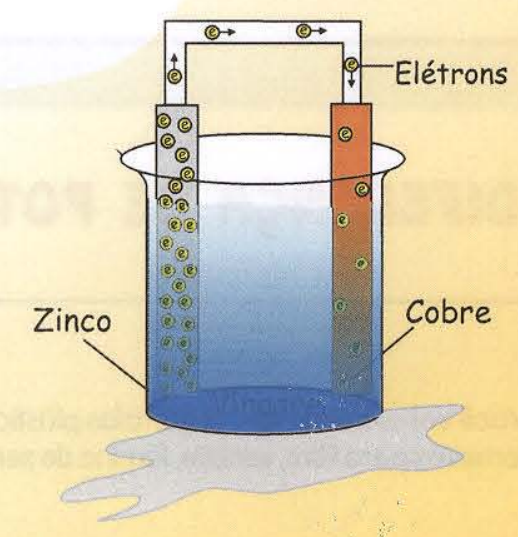

Nossa, realmente a pilha é uma invenção incrivel!!! - disse Marcelo. - Quem foio gênio que a inventou?

- Eu não sei - respondeu Patrícia. - Mas posso procurar.

No dia seguinte, lá estava ela com todo o histórico da pilha.

- Pessoal, aqui está toda a história da pilha - gritou Patrícia, mostrando algumas anotações. - Tudo começou com nativos da África e da América do Sul que sofriam choques dolorosos quando tocavam em um peixe típico de rios tropicais "nosso famoso poraqué". Isso despertou a curiosidade de vários cientistas, entre eles Luigi Galvani (1737 - 1798), que nessa época estavam estudando a contração dos músculos das pernas das rãs. Ele observou em 1786, que os músculos das rãs penduradas em ganchos de cobre numa grade de ferro contraíam-se. Esse efeito ele chamou de "eletricidade animal".

Essa descoberta atraiu a atenção de vários cientistas da época, entre eles Alessandro Volta (1745 1827), que ao refazer a experiência de Galvaniem meados de 1790, comprovou que a corrente elétrica era produzida por reações químicas.

Páq.06 
- Com uma pilha similar a essa, em 1801 disse Patrícia, mostrando uma foto - Volta foi condecorado por Napoleão Conde e Senador do reino da Lombardia, mas suas ideias não eram muito cientificas.

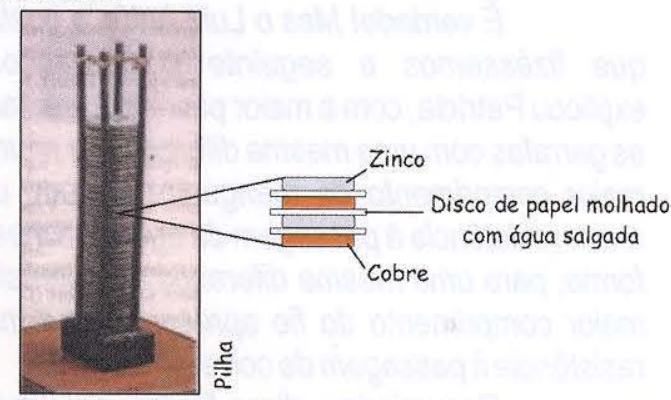

Eela prosseguia:

- Ele construiu a pilha com uma série de pares de discos de dois metais diferentes (zinco e cobre) intercalados com discos de papel molhado com água salgada. Cujo princípio de funcionamento é semelhante a que construimos.

Hoje os cientistas estão preocupados em construir pilhas com uma maior durabilidade. Inclusive, eu trouxe uma foto que mostra isso.

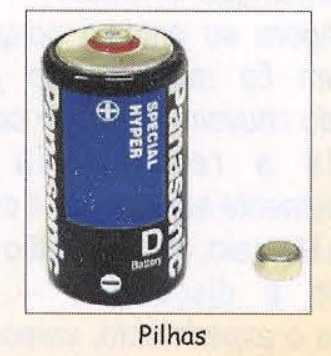

Logo após a explicação de Patrícia, saíram do quarto para tomar um suco, preparado pela mãe de Marcelo. Pedro, encantado com as recentes descobertas, resolveu ficar lendo sobre 0 assunto. Quando os garotos voltaram...

- Pessoal! - disse ele, empolgadíssimo mostrando o livro aos colegas - Aqui eu encontrei algumas informações sobre a intensidade da corrente elétrica.

- Grande coisa - disse Tales.

Pedro continuava sua explicação sem dar atenção para o cometário de Tales, lendo um trecho do livro para os colegas.

- "A intensidade da corrente elétrica, i, através de uma secção é dada pela relação entre a quantidade de carga e o intervalo de tempo".

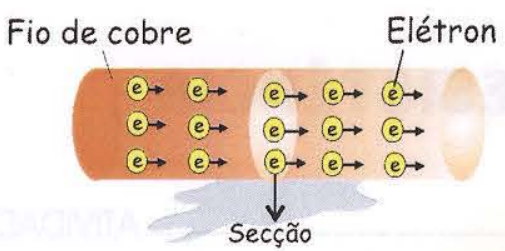

Durante a explicação de Pedro, Tales ficou planejando uma forma de desafiá-lo. E na primeira oportunidade fez uma pergunta.

- Pedro, você poderia falar sobre a resistência elétrica dos metais. - Boa pergunta!!!! - exclamou Marcelo. - Vamos enviá-la para o site.

- Calma Marcelo, vamos primeiro pensar sobre o assunto - disse Pedro, com uma expressão preocupada. Nós sabemos que a resistência se opõe à passagem de corrente elétrica.

Pensaram, discutiram... Mas não chegaram a nenhuma conclusão e para a alegria de Marcelo, fanático por computadores, enviaram um e-mail para o site pedindo ajuda. Antônio.

Logo veio a resposta com uma proposta do Luiz

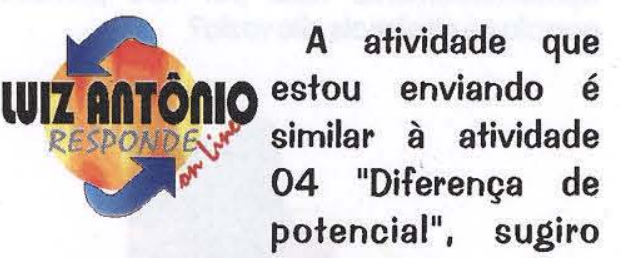

apenas algumas modificações. Com ela vocês poderão responder como se comporta a resistência elétrica de alguns materias. Sendo o fluxo de elétrons representado pelo fluxo de água, o fio pela mangueira $e$ as garrafas pelas placas de zinco e de cobre. 


\section{RESISTÊNCIA}

Você vai precisar de: 4 garrafas plásticas de refrigerante de $2 \mathrm{~L}, 5,5 \mathrm{~m}$ de mangueira de $1 \mathrm{~cm}$ de diâmetro, 4 torneiras para filtro, estilete, lâmina de serra, tesoura e água com corante (suco de laranja).

- Utilizando o mesmo procedimento da atividade 04 , conecte uma mangueira de 50 $\mathrm{cm}$ de comprimento e $1 \mathrm{~cm}$ de diâmetro em duas garrafas vazias de 2l. Faça o mesmo, em outro par de garrafas, com uma mangueira de 5 m de comprimento e $1 \mathrm{~cm}$ de diâmetro. Encha as garrafas com água pela metade.

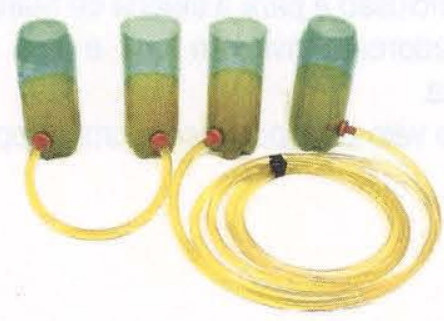

2 - Em seguida, coloque simultaneamente uma garrafa, de cada par, sobre uma superficie de $20 \mathrm{~cm}$ de altura aproximadamente Qual par terá primeiro a garrafa no nivel mais alto vazia?

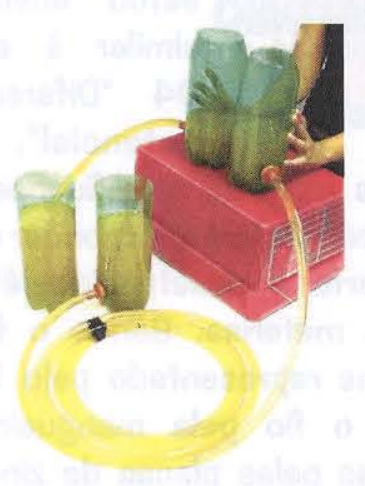

- Nossa, que legal! - exclamou Tales, fazendo a experiência. - O par de garrafas com a mangueira de menor comprimento tem a garrafa no nivel mais alto esvaziada primeiro.

É verdade! Mas o Luiz Antônio gostaria que fizéssemos a seguinte comparação: explicou Patrícia, com a maior paciência - estando as garrafas com uma mesma diferença de altura, 0 maior comprimento da mangueira oferece uma maior resistência à passagem da água. Da mesma forma, para uma mesma diferença de potencial o maior comprimento do fio apresenta uma maior resistência à passagem de corrente elétrica.

- Resumindo - disse Pedro, para fixar a explicação - a resistência depende do comprimento do fio. Vejam bem, nós também podemos afirmar que, quanto mais grosso for o fio, maior será a corrente elétrica que passará por eleconcluiu ele, lembrando da aula sobre esse assunto.

- É verdade, imaginem se essa mangueira fosse bem grossa, a água passaria rapidamente de uma garrafa para outra - falou Tales, com a mangueira na mão.

- Agora eu entendi porque o meu pai comprou um fio mais grosso para usar na instalação do chuveiro daqui de casa. Assim, ele diminuiria a resistência elétrica $\theta$ consequentemente aumentaria a corrente elétrica - comentou Marcelo, que até então estava apenas observando a discussão. - Já que nós entendemos o experimento, vamos enviar um email para o site descrevendo nossas discussões.

- Está bem, Marcelo - concordou Pedro, sorrindo-Envie logo esse e-mail!

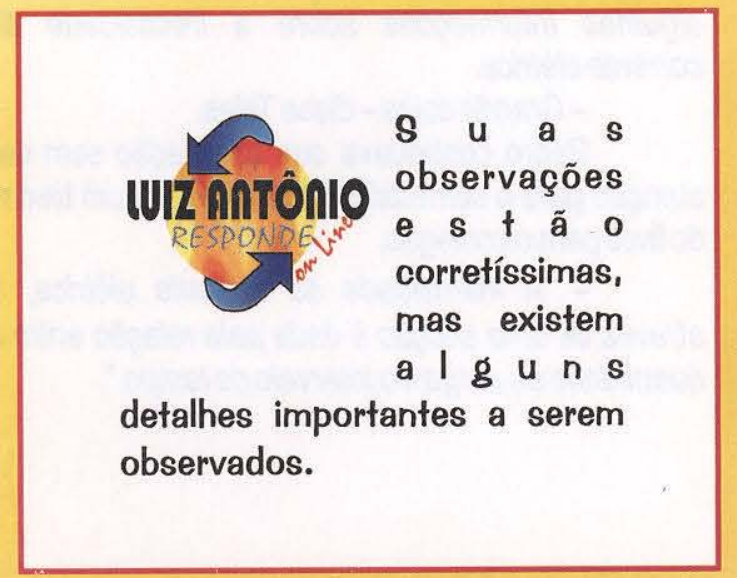




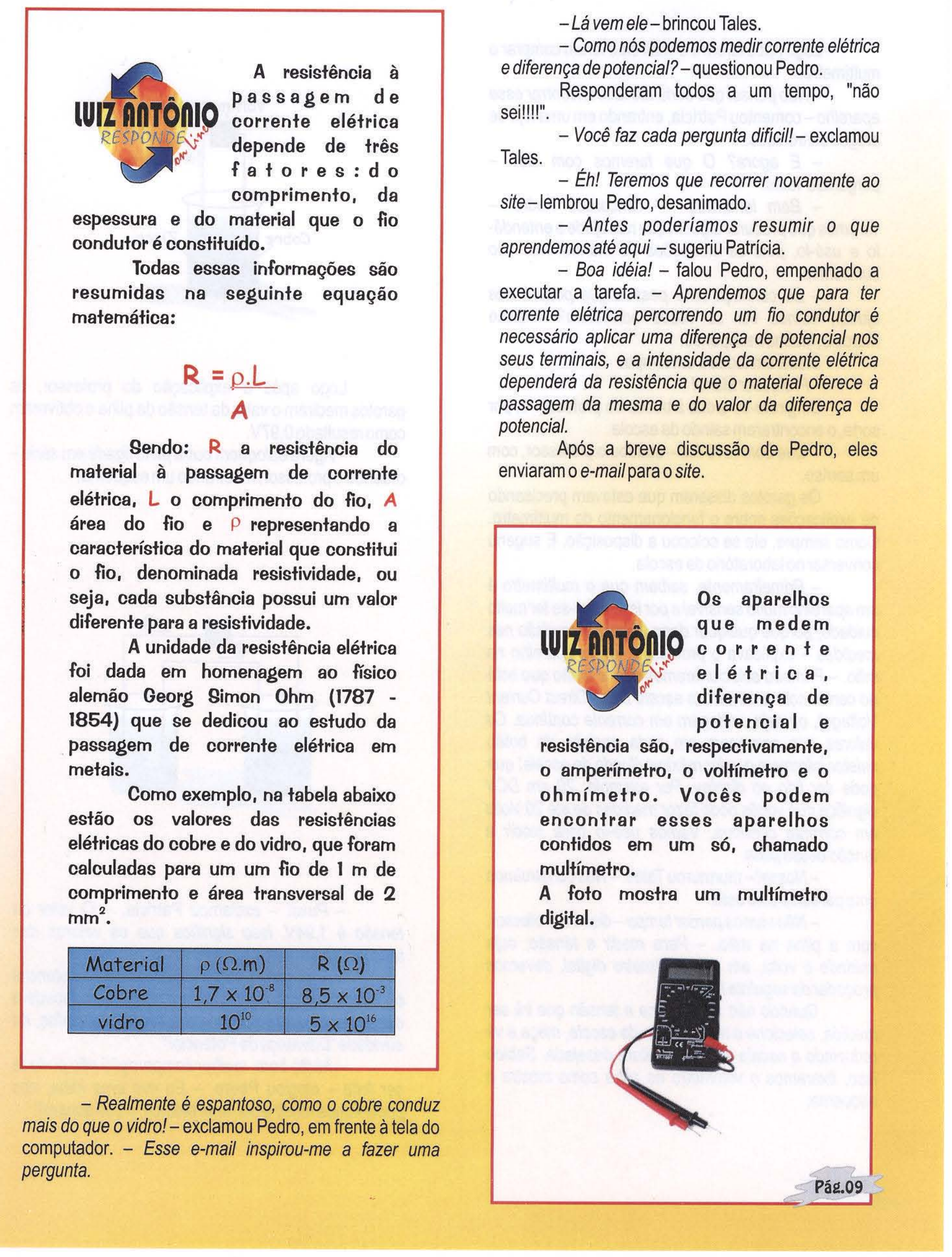


multímetro.

Logo após lerem o e-mail eles foram comprar o

- Não pensei que seria tão fácil encontrar esse aparelho - comentou Patrícia, entrando em uma loja de artigos eletrônicos.

- E agora? O que faremos com ele? perguntou Tales.

- Bem lembrado - concordou Pedro. Teremos que procurar alguém que nos ajude a entendêlo e usá-lo, pois as instruções do manual não são suficientes.

- Eu conheço uma pessoa que poderá nos ajudar, vamos ver se vocês adivinham? - disse Marcelo, fazendo suspense.

Disseram todos a um tempo.

- Professor Mário!

Dirigiram-se todos à busca do professor e, por sorte, o encontraram saindo da escola.

- Que bom revê-los - saudou o professor, com um sorriso.

Os garotos disseram que estavam precisando de explicações sobre o funcionamento do multímetro. Como sempre, ele se colocou a disposição. E sugeriu conversar no laboratório da escola.

- Primeiramente, saibam que o multímetro é um aparelho muito sensivel e por isso deve-se ter muito cuidado, porque qualquer dano afetará a precisão nas medidas - explicava o professor, com o aparelho na mão. - Primeiro selecionaremos com o botão que está ao centro com uma seta, a escala DCV (Direct Current Voltage), ou seja, voltagem em corrente contínua. Os valores que aparecem em cada posição do botão seletor informam o valor máximo (fundo de escala) que pode ser lido no display. Por exemplo: $20 \mathrm{em} \mathrm{DCV}$ significa que vocês pode fazer medidas de até 20 Volts em corrente contínua. Vamos usá-lo para medir a tensão dessa pilha.

- Nossa! - murmurou Tales. - Nós construímos uma parecida com esta.

- Não vamos perder tempo - disse o professor, com a pilha na mão. - Para medir a tensão, cuja unidade é volts, em um multímetro digital, devemos proceder da seguinte forma:

Quando não se conhece a tensão que irá ser medida, selecione o maior fundo de escala, meça e vá reduzindo a escala até obter leitura desejada. Sabido isso, fixaremos o voltimetro na pilha como mostra 0 esquema.

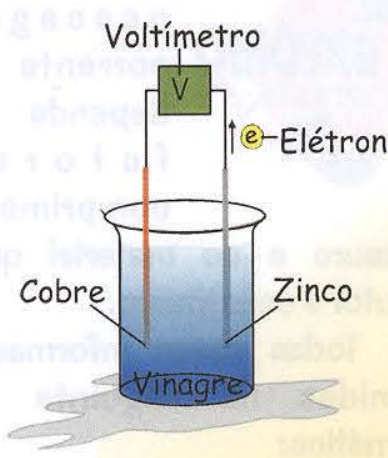

Logo após a explicação do professor, os garotos mediram o valor da tensão da pilha e obtiveram como resultado $0,97 \mathrm{~V}$.

- Agora coloquem outra pilha ligada em série ordenou o professor, mostrando um esquema.

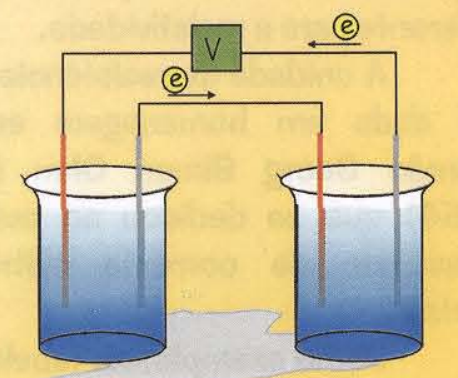

- Puxa! - exclamou Patrícia. - O valor da tensão é $1,94 \mathrm{~V}$. Isso significa que os valores das tensões se somam.

- Ah! - gritou Tales. - A diferença de potencial ou tensão das pilhas ligadas em série, corresponde a dobrarmos a diferença de altura entre as garrafas, na atividade "Diferença de Potencial".

- Muito bem, melhor comparação não poderia ser feita - elogiou Pedro. - Eu tive uma idéia, nós poderiamos medir a corrente elétrica, o que acham? 
- Gostei da sua sugestão, Pedro - falou Mário, que até então estava apenas observando os garotos.

- Professor, precisaremos da sua ajuda para ligaro amperímetro-avisou Pedro.

- É simples - disse ele. - Para medir a corrente elétrica, cuja unidade básica é o Ampère, em um multímetro digital, deve-se colocá-lo na escala de corrente contínua ou DCA (Direct Current Ampère).

A letra $m$ (mili) que encontra-se junto de algumas escalas significam que o valor lido no display deve ser dividido por 1.000 .

Eele prosseguia:

- Qual é o valor da corrente elétrica nessa montagem?-questionou oprofessor.

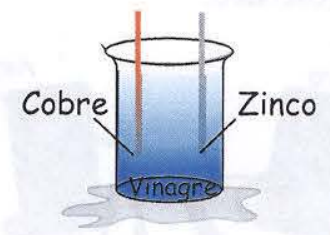
aberto.

- Zero-respondeu Pedro. - Porque o circuito está

- Correto! - disse o professor. - E nessa montagem, qual é o valor da corrente elétrica?

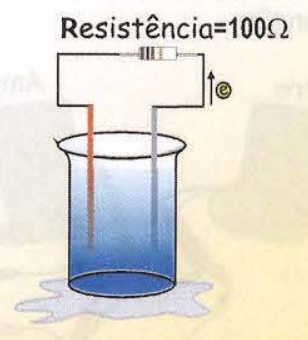

- Não sei-respondeu Pedro.

- O que é isso? - falou Tales, apontando para o novo componente do circuito elétrico.

- Uma resistência elétrica - explicou o professor. Elas são facilmente encontradas em lojas de artigos eletrônicos. Para medir o valor da corrente elétrica nessa montagem ligaremos o amperímetro em série com a resistência elétrica no circuito.

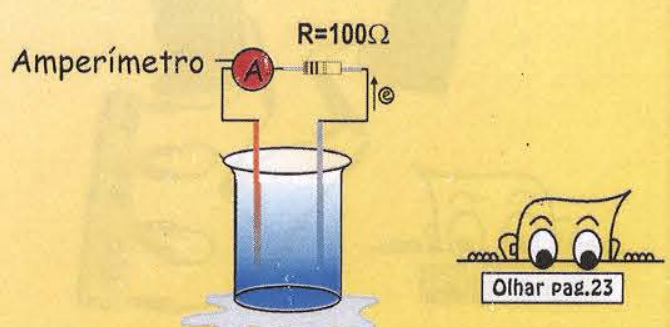

- Vocês sabiam que em nossa casa, temos um aparelho com uma função similar à do amperímetro - falava o professor, enquanto os garotos montavam o circuito.

-Qual?-perguntou Tales.

- O marcador do hidrômetro - respondeu ele. - O hidrômetro é aquele aparelho que normalmente fica no jardim. Ele é colocado em série na tubulação, que distribui a água, e seu marcador medi o consumo de água nas residências.

Fez um pausa e continuou:

- Mas voltemos ao nosso experimento. Agora, com a montagem pronta, liguem o amperímetro no maior valor de fundo de escala, meça e vá reduzindo a escala até obter um valor fácil deler.

- Ok! - exclamou Patrícia. - Olhem que estranho os números marcados no amperímetro estão decaindo!

- Me desculpem, esqueci de dizer que vocês devem esperar o valor da corrente no amperímetro estabilizar-explicou o professor.

Após seguirem as suas instruções os garotos mediram a corrente elétrica.

- Ah! - lembrou Mário. - O tamanho das placas e o contato delas com a solução são fatores determinantes para a corrente elétrica, por isso não esperem obter sempre o mesmo resultado.

E mais, com o passar do tempo, as placas se oxidarão, isto é, criar-se-á uma camada isolante sobre elas. Dado o recado, continuemos: coloquem duas pilhas ligadas em série como mostra 0 esquema. Qual o valor da corrente elétrica nessa montagem?

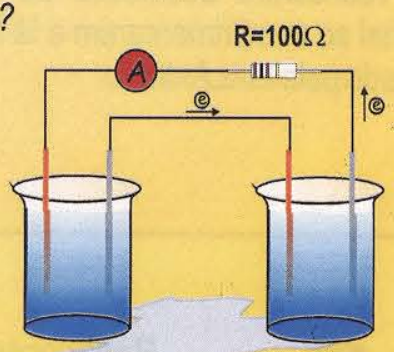

- O valor da corrente elétrica aumentou respondeu Patricia, após fazer a leitura no amperímetro - Pensando bem, esse resultado está correto, afinal se aumentamos o número de pilhas, a corrente também aumentará. Isso é análogo a aumentarmos a altura entre o par de garrafas conectadas por uma mangueira e preenchidas pela metade com água, pois quanto maior a diferença de altura entre elas, maior será o fluxo de água. - Muito bem, garota - elogiou 0 professor.

Páq.11 
- O que são esses riscos coloridos impressos na resistência elétrica? - perguntou Tales, enquanto os garotos desmontavam a pilha.

- Infelizmente essa dúvida será esclarecida em uma outra ocasião, porque eu tenho um compromisso agora. Não se esqueçam! Antes de ligar o amperímetro deixem-no no maior fundo de escala, porque se a corrente elétrica for alta ele não será danificado - enfatizou o professor, saindo do laboratório.

Sairam dali e foram direto para a casa de Marcelo.

- Enquanto caminhava - falou Patrícia, ao chegar na casa de Marcelo - pensei em tudo que aprendemos e ocorreu-me uma dúvida. Qual é a relação entre: diferença de potencial e corrente elétrica?

- Eu adoraria respondê-la - disse Marcelo. Mas meus conhecimentos de física "ainda" são limitados. O melhor a fazer é enviar um e-mail para 0 Luiz Antônio.

- Calma! - disse Pedro - Vamos pensar um pouco, se não acharmos a solução para o problema, aí sim procuramos o Luiz Antônio.

- O Pedro sempre procura o caminho mais difícil-resmungou Tales.

Pensaram, discutiram... mas não encontraram a resposta para a dúvida de Patrícia. Quando Pedro percebeu que os garotos estavam se dispersando, ele reconheceu que o melhor a fazer naquele momento era escrever para o site, mas deixaram para ver a resposta no outro dia, afinal já era tarde.

0 reencontro aconteceu às $14: 00 \mathrm{~h}$ do dia seguinte, mal se cumprimentaram e lá foram eles ler 0 e-mail enviado pelo Luiz Antônio.

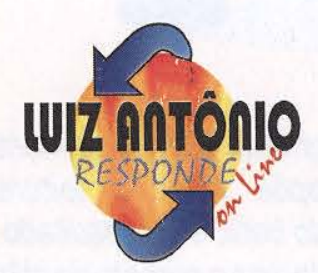

Realmente existe

uma relação entre diferença de potencial e corrente elétrica e, vocês irão

descobrí-Ia

realizando a atividade que estou enviando.

\section{Leide Ohm}

ATIVIDADE 06

Você vai precisar de: 3 suportes para pilhas grandes, 3 pilhas grandes de 1,5V, 7 jacarés, 1 amperimetro, 1 voltimetro e 1 resistência de $100 \Omega$

7 - Monte o circuito como mostra a foto abaixo. A escala deverá ser ligeiramente maior que $100 \mathrm{~mA}$ no amperimetro e $10 \mathrm{~V}$ no voltimetro. Meça o valor da corrente no amperímetro e da tensão no volfimetro.

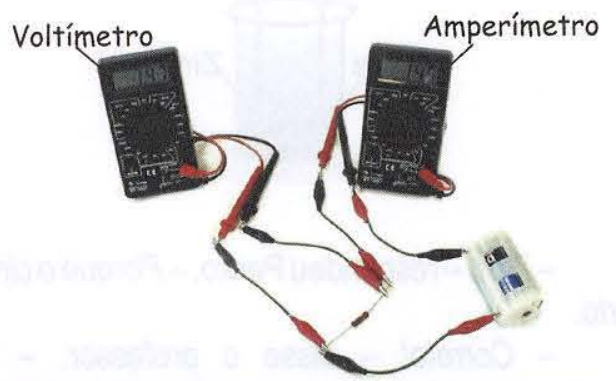

- Monte o mesmo circuito, mas com duas pilhas. Meça o valor da corrente elétrica e da tensão.

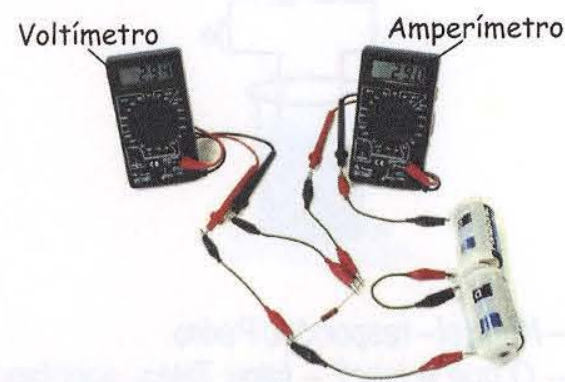

3

Monte o mesmo circuito com três pilhas. Meça o valor da corrente elétrica e da tensão. Em seguida coloque todos os resultados obtidos em uma tabela e observe a relação existente entre os valores da tensão e da corrente elétrica.

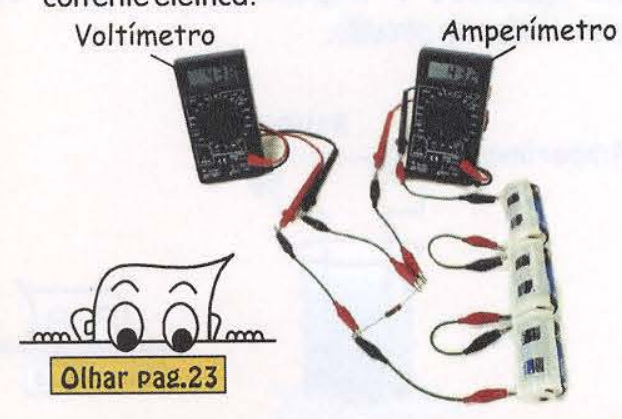


Para facilitar a montagem dos circuitos estou enviando os esquemas.
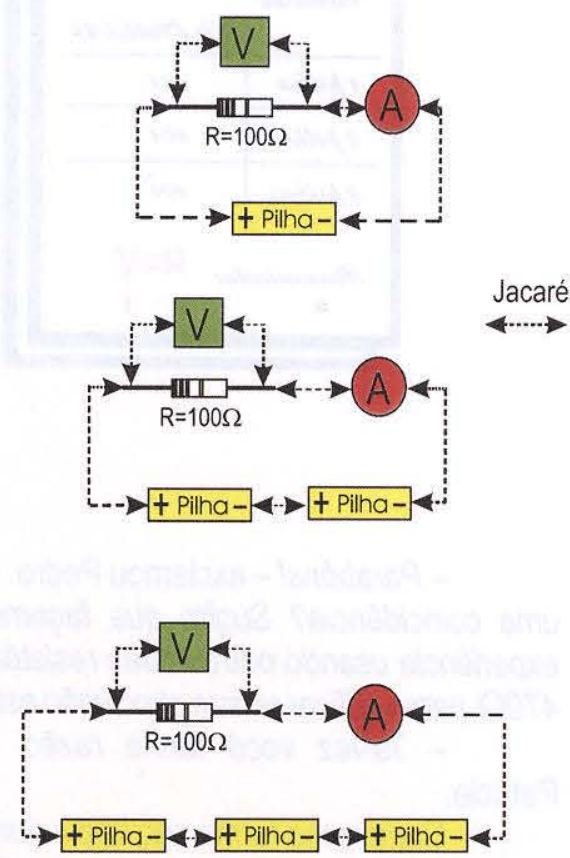

\section{voltímetro.}

A letra $A$ representa o amperímetro e $\mathrm{V}$

Atenção: As pilhas devem ser associadas com o pólo positivo de uma, ligando ao pólo negativo da outra.

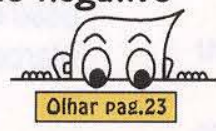

Logo que leram o e-mail saíram à busca dos materiais para executar a atividade. Por sorte, encontraram um vendedor muito prestativo que se prontificou a explicar o código de cores impresso nas resistências.

- Garotada!!! Cada cor dos riscos impressos na resistência representa um número.

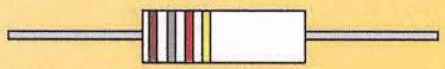

\begin{tabular}{|l|l|l|l|l|l|l|l|l|l|l|l|l|}
\hline Preto & Marrom Vermelho Laranja & Amarelo & Verde & Azul Violeta & Cinza & Branca \\
\hline
\end{tabular} 0

\begin{tabular}{l|l}
3 & 4
\end{tabular}

As faixas devem ser lidas da extremidade esquerda para o centro do resistor. A primeira faixa, representa 0 primeiro algarismo do valor da resistência. $A$ segunda faixa representa o segundo algarismo. A terceira faixa representa a potência de 10 pela qual deve ser multiplicado - número formado pelos dois algarismos anteriores e a quarta faixa representa a imprecisão na fabricação do resistor. Esta imprecisão é dada como uma porcentagem do valor do resistor, por exemplo: se a quarta faixa for prateada o resistor deverá representar 10\% de imprecisão, dourada $5 \%$ de imprecisão e se não houver a Quarta faixa 20\% de imprecisão. Para não ficar dúvidas vamos conferir o valor dessa resistência que vocês estão comprando.

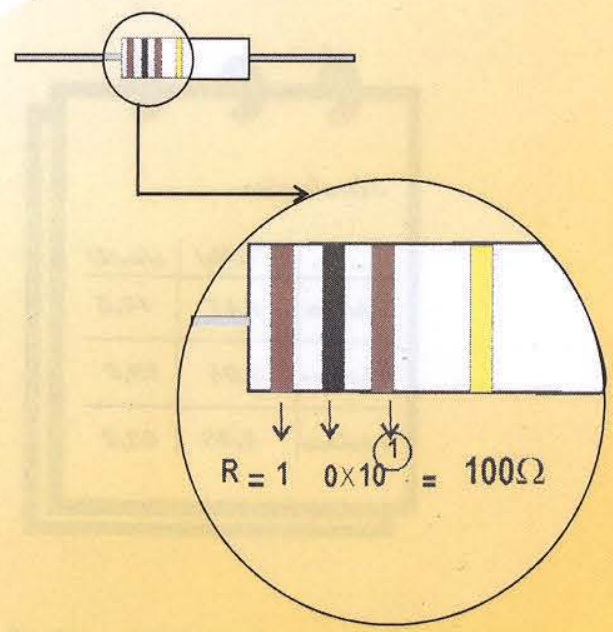

Após a leitura, Patrícia questionou o vendedor sobre a quarta faixa dourada.

- A faixa dourada nos fornece a informação que a tolerância ou imprecisão é de $5 \%$ nessa resistência, isso quer dizer que 0 valor dela pode variar de 95 a 105. Posso embrulhar essa resistência? - perguntou 0 vendedor, depois da explicação.

Sim-respondeu Pedro.

Saíram da loja ainda mais motivados a descobrir a relação entre diferença de potencial e corrente elétrica. Ao chegar na casa de Marcelo foram logo montando o circuito.

Porque colocar o amperímetro em série? - perguntou Tales, enquanto montavam a atividade.

- Tales, é simples, observe esse esquema do circuito - explicou Pedro, sempre com muita paciência.

Pág. 13 


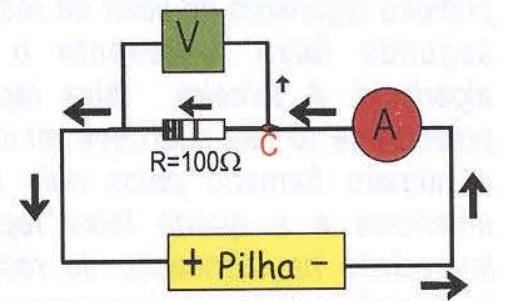

- O amperímetro deve ser colocado em série no circuito para que toda corrente elétrica passe por ele.

Após o esclarecimento da dúvida de Tales, fizeram as medidas.

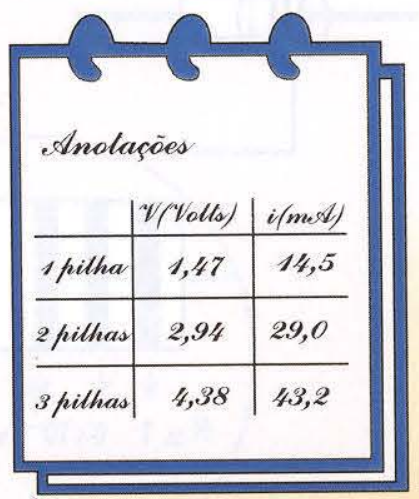

- E agora o que faremos com isso? - perguntou Tales, olhando para os números.

- Vamos olhar para os valores obtidos no voltímetro e no amperímetro e tentar obter uma relação entre, tensão, ou seja, diferença de potencial e corrente elétrica-respondeu Pedro.

Pensaram, pensaram... Mas logo desistiram e resolveram deixar para continuar a discussão no dia seguinte. Na saída Patrícia pegou a tabela, sem que os colegas percebessem e ao chegar em casa persistiu na análise. Quando já estava quase desistindo, percebeu a relação entre a tensão e a corrente elétrica. Mal pôde esperar amanhecer, tamanha era sua satisfação por ter decifrado o enigma.

- Eureca, eureca! - disse Patrícia, imitando Arquimedes e mostrando seu caderno de anotações. Olhem, se nós dividirmos a tensão pela corrente, obteremos números bem parecidos, e eles são justamente o valor da resistência usada no circuito.

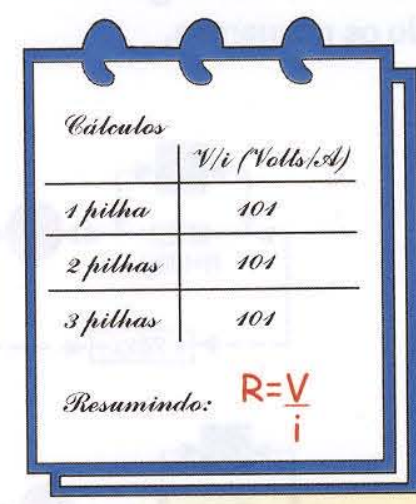

- Parabéns! - exclamou Pedro. - Mas não fol uma coincidência? Sugiro que façamos a mesma experiência usando outras duas resistências $270 \Omega$ e $470 \Omega$ para verificar se sua conclusão está correta.

- Talvez você tenha razão - concordou Patrícia.

Como essa turma não deixa nenhuma dúvida no ar, foram conferir se realmente Patrícia havia decifrado o enigma colocado pelo Luiz Antônio.

- Essa equação vale para essas resistências também! - comentou Pedro. - Após colher o último resultado.

- O Luiz Antônio não vai acreditar quando ler esse e-mail, afinal nós desvendamos o enigma - dizia Marcelo, enquanto escrevia para o site. 
A resposta do site colaborou para aumentar a auto-estima dos garotos. Enquanto gabavam-se com a redescoberta, Marcelo navegava na internet e, por acaso, encontrou um site que tinha várias biografias de físicos.

- Pessoal - gritou ele. - Venham ver esse site.

- Que jóia! - exclamou Patrícia, olhando para a tela do computador. - Procure a biografia de Ohm!

- Aqui está - mostrou Marcelo.

- Nossa! Tem tudo sobre a vida dele comentou Pedro, e em voz alta leu um trecho do texto. - Georg Simon Ohm (1787 - 1854) fez experiências em um condutor, de janeiro de 1825 a janeiro de 1826 , descobrindo após esse período de trabalho a lei de $\mathrm{Ohm}$.

- Eu ainda tenho minhas dúvidas se essa lei vale para todos os condutores - avisou Pedro.

Após o comentário de Pedro, desencadeouse uma discussão entre ele e Patrícia. Ela não tinha dúvidas que a lei valia para todos os condutores. 0 desfecho do episódio terminou com um e-mail para o site, que constava toda discussão sobre a validade da leide Ohm.

A resposta dessa vez, demorou a chegar, enquanto esperavam Marcelo mostrou a primeira música que tinha aprendido a tocar no violão.

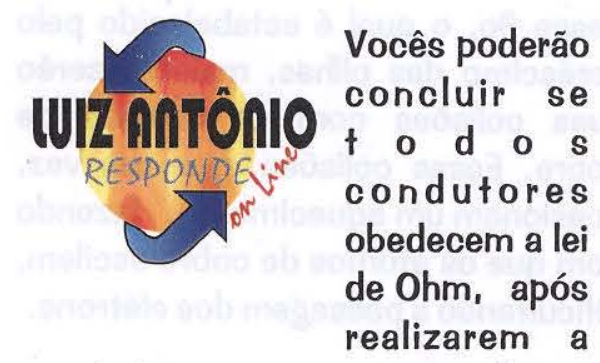

atividade que estou enviando. 0 circuito proposto é semelhante ao da "Atividade 06". Vocês irão averiguar se a relação entre a diferença de potencial e a corrente elétrica é constante para a resistência do fio de tungstênio que se encontra dentro do bullbo da lâmpada.

\section{Resistência de uma lâmpada}

ATIVIDADE 07

Você vai precisar de: 3 suportes para pilhas grandes, 3 pilhas grandes de 1,5V, 7 jacarés, 1 amperímetro, 1 voltimetro, 1 lâmpada de 6V.

\section{7 - Monte o circuito como mostra a foto. A escala deverá ser ligeiramente maior que $100 \mathrm{~mA}$ no amperímetro e $10 \mathrm{~V}$ no voltímetro.}

Meça o valor da corrente no amperímetro e da tensão novoltimetro.

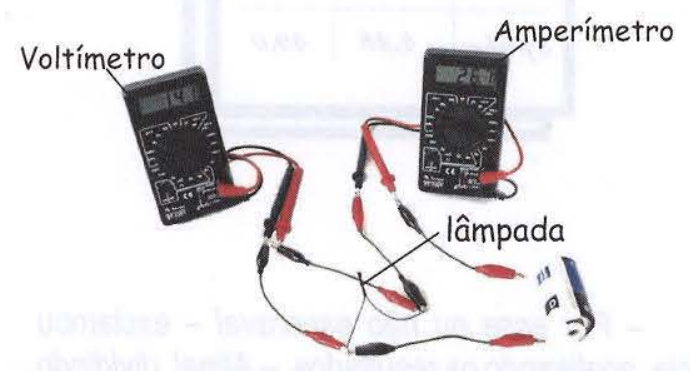

- Monte o mesmo circuito, mas com duas pilhas. Meça o valor da corrente elétrica e da tensão.

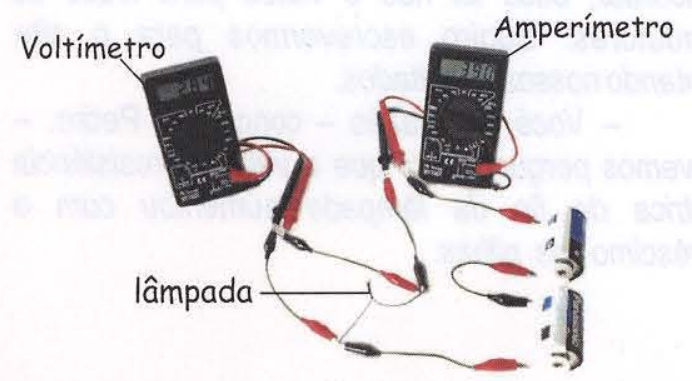

2

- Monte o mesmo circuito, com três pilhas. Meça o valor da corrente elétrica e da tensão. Em seguida coloque todos os resultados obtidos em uma tabela e observe a relação existente entre eles.

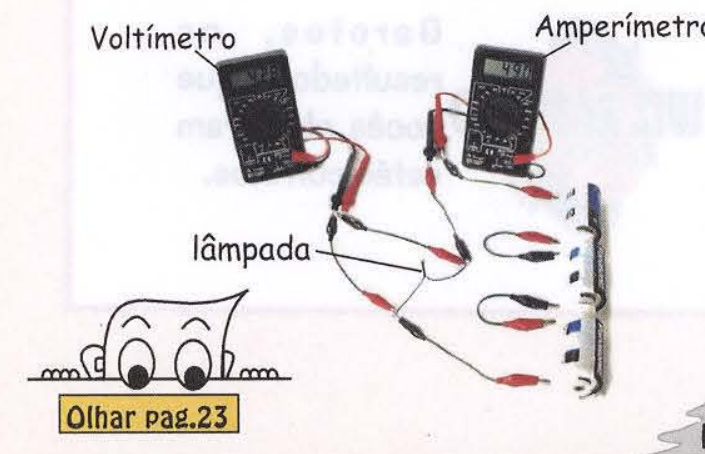


Montaram o circuito e obtiveram os seguintes resultados:

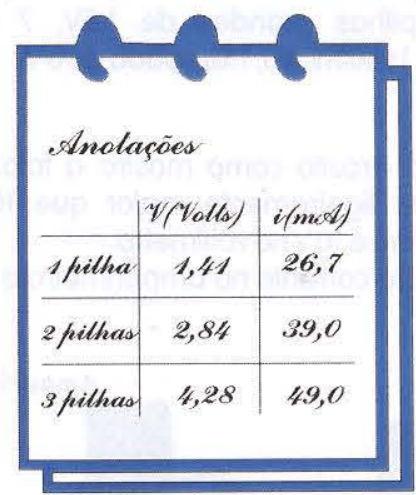

- Por essa eu não esperava! - exclamou Patrícia, analisando os resultados. - Afinal, dividindo a diferença de potencial pela corrente elétrica não obtivemos o mesmo valor. Sou obrigada a concordar, essa lei não é válida para todos os condutores. Sugiro escrevermos para o site contando nossos resultados.

- Você tem razão - concordou Pedro. Devemos perguntar por que o valor da resistência elétrica do fio da lâmpada aumentou com o acréscimo das pilhas.

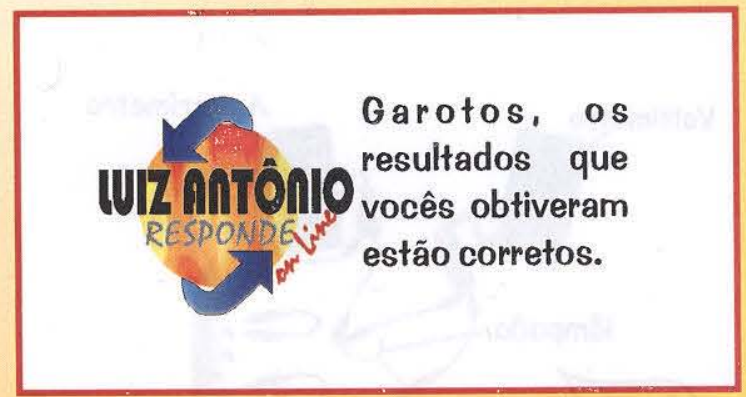

Pág.16

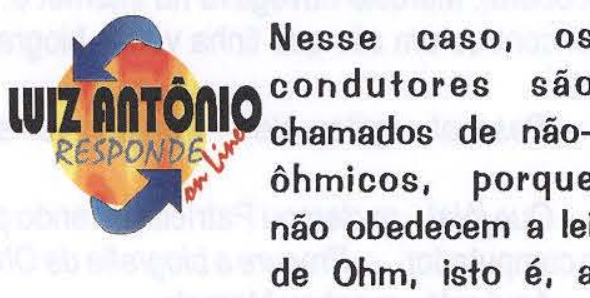

resistência elétrica do filamento da lâmpada não é a mesma para diferentes tensões.

Como uma ilustração desse fato, a figura a seguir representa um fio de tungstênio com os átomos que o compóe e os elétrons circulando por ele quando é estabelecida uma diferença de potencial.

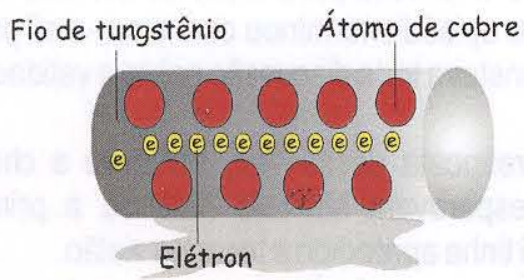

Quanto maior o fluxo de elétrons nesse fio, o qual é estabelecido pelo acréscimo das pilhas, maiores serão suas colisões com os átomos de cobre. Essas colisóes, por sua vez, ocasionam um aquecimento, fazendo com que os átomos de cobre oscilem, dificultando a passagem dos elétrons.

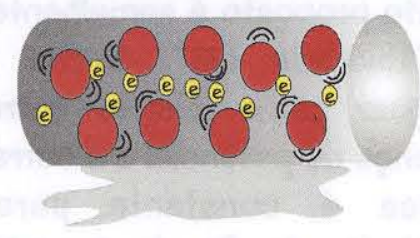

Na lâmpada o aquecimento do fio de tugstênio é em torno de $2.500^{\circ} \mathrm{C}$. 


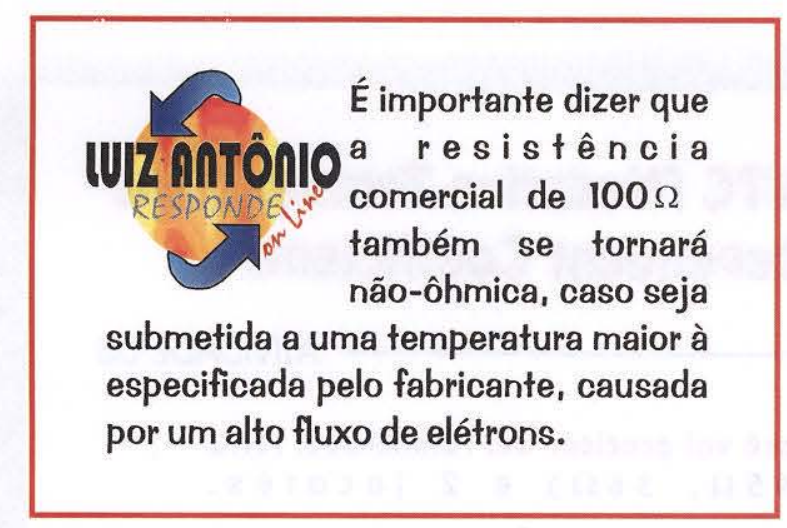

- Essa tal resistência elétrica só atrapalha concluiu Tales, após ler o e-mail.

- Sabe que você tem razão - concordou Patrícia, mas não prosseguiu com a discussão.

Pedro, pensativo, sentou no sofá e ficou refletindo sobre as observações dos colegas. Enquanto isso, os outros navegavam pela internet, procurando joguinhos. Passado algum tempo, ele, ainda muito intrigado, sugeriu que Marcelo enviasse um e-mail para o site do Luiz Antônio perguntando se a resistência elétrica sempre prejudica o funcionamento do circuito.

Todos concordaram e, a resposta dada pelo professor Luiz Antônio veio imediatamente.
Para vocês comprovarem o que foi dito, estou enviando uma atividade. Escrevamme após realizarem a experiência.

\section{LOR flight dependent Resistor)}

\section{ATIVIDADE 09}

Você vai precisar de: 1 ohmimetro, 1 LDR $10,2 \mathrm{~K}$ e $52 \mathrm{~K}) \Omega$ e 2 jacarés.

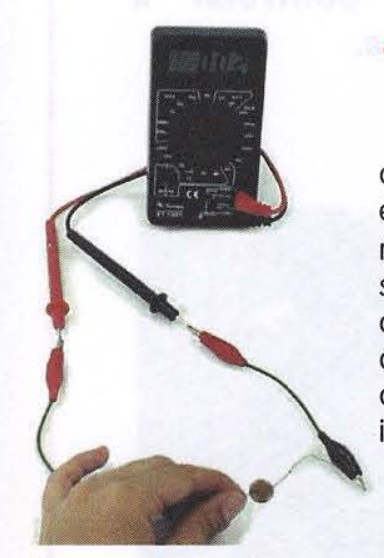

- Monte o circuito como mostra a

foto. O ohmimetro deverá estar em uma escala ligeiramente maior que $100 \mathrm{~K} \Omega \mathrm{Em}$ seguida meça o valor da resistência do LDR, quando ele estiver completamente iluminado.

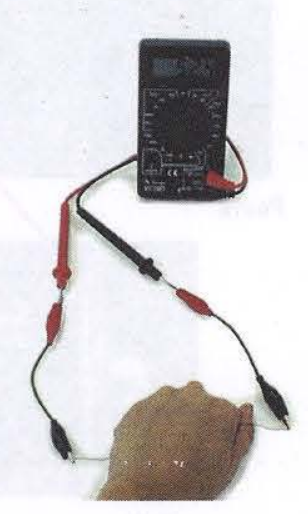

Porém, em determinadas siłuações a resistência pode ser benéfica, como por exemplo, ferro elétrico e chuveiro elétrico, pois ela proporciona geração de calor.

Os cientistas ao comprovarem tal fato, desenvolveram dispositivos que podiam ter sua resistência elétrica controlada externamente. Sendo essas resistências muito usadas nos circuitos atualmente.

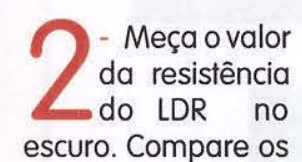
escuro. Compare os resultados obtidos.

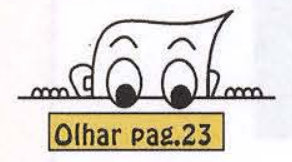

- É verdade! A resistência elétrica do LDR varia com a luz! - exclamou Tales, encantado com a novidade.

- Olhem! Conforme ele vai sendo exposto à luzo valor da sua resistência elétrica aumenta - falou Pedro, fazendo uma demonstração.

- Marcelo envie um e-mail, contando essas observações e pergunte também onde ele é usado pediu Patrícia.

Pág. 17 


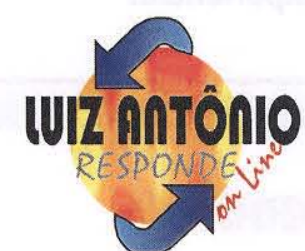

O LDR é um dispositivo feito de um $\mathrm{m}$ a t e ri a semicondutor ch a m a do: sulfeto de chumbo, cuja resistência elétrica varia com a intensidade de luz que incide sobre ele. Uma de suas utilizações é controlar a iluminação pública.

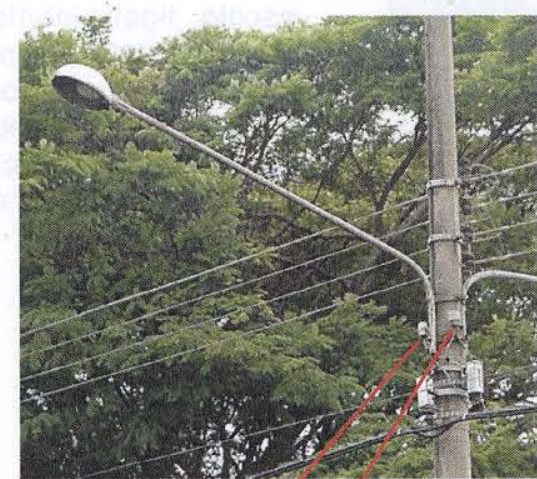

Poste

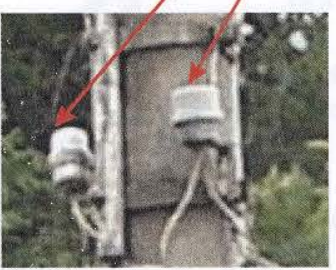

LDR

Estou enviando uma atividade que mostra outro dispositivo cuja resistência elétrica é controlada externamente.

Páq. 18

\section{NTC (Negative Temperature Dependent Coefficient)}

\section{ATIVIDADE 08}

Você vai precisar de: 1 ohmimetro, 1 NTC

$(45 \Omega, 36 \Omega)$ e 2 jacarés.

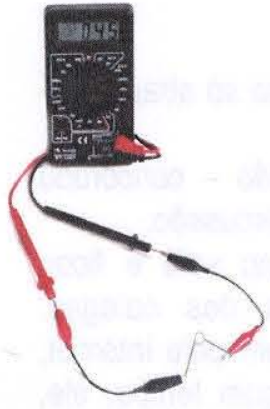

7 - Monte o circuito como mostra a

foto. O ohmímetro deverá estar em uma escala ligeiramente maior que $100 \Omega$ Meça o valor da resistência do NTC.<smiles>c1ccccc1</smiles>
Coloque o NTC entre os dedos para a quecê-lo um pouco. Depois de 1 minuto meça o valor da resistência.
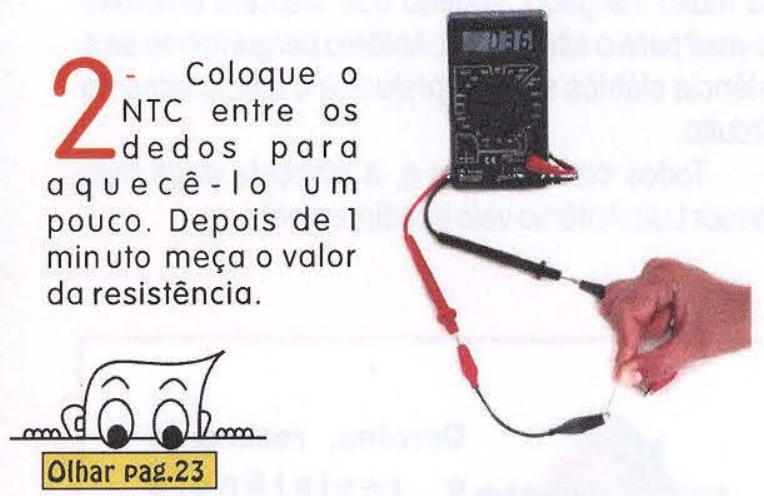

Os garotos assim que leram o e-mail foram comprar o NTC na loja de artigos eletrônicos. Mas, a curiosidade deles era tão grande que logo voltaram para montar o circuito.

- Reparem o valor da resistência do NTC no ohmímetro - disse Marcelo. - Agora irei colocá-lo entre meus dedos, percebam que a resistência diminui como aumento da temperatura, fornecido pelo meu corpo.

- Pessoal já é tarde, eu preciso ir embora - avisou Patrícia.

- Mas não deixemos para amanhã o que podemos fazer hoje - brincou Pedro. - Vamos contar ao Luiz Antônio que a resistência diminuiu com o aumento da temperatura e aproveitamos para perguntar onde esse dispositivo é usado.

Marcelo se prontificou a realizar a tarefa.

No dia seguinte lá estavam eles ansiosos para mais descobertas. 


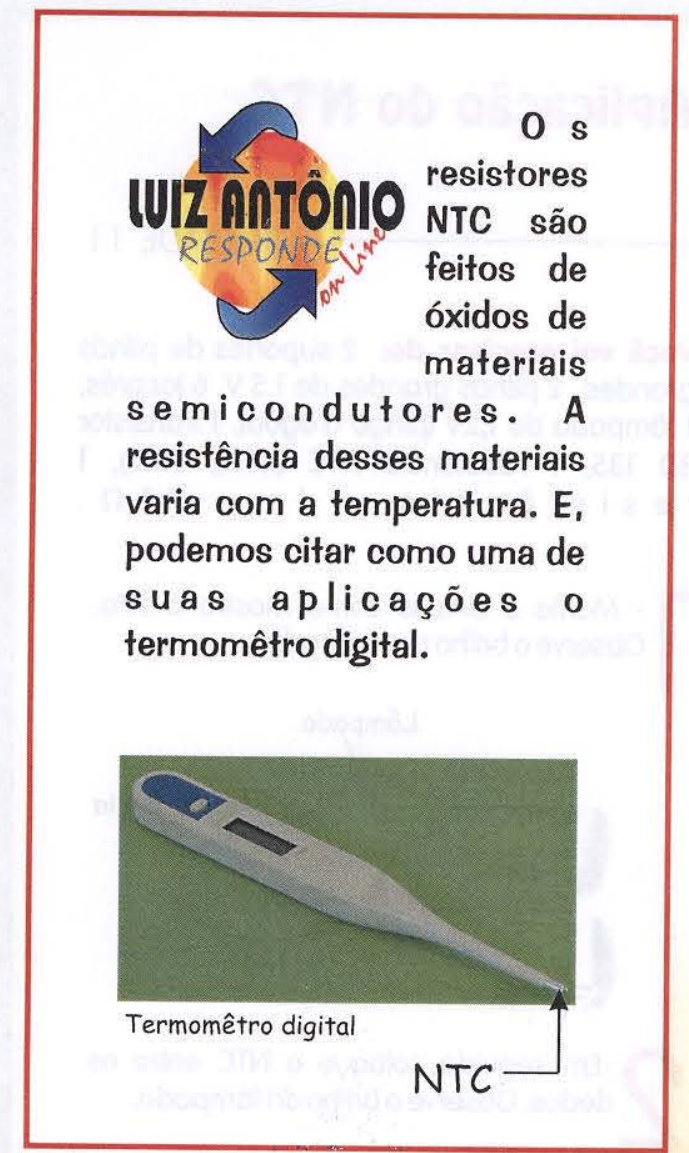

Após lerem o e-mail, foram ao shopping comer um lanche.

- Como estão esses jovens cientistas? - brincou o professor. - Posso me sentar?

- Lógico!-exclamou Patrícia.

Tales, sem esperar qualquer comentário, foi logo contando todas as descobertas, terminando 0 relato com as aplicações do NTC e LDR.

- Vocês sabiam que além desses dispositivos, existe um outro ainda mais interessante chamado transistor, cuja resistência é controlada externamente pelo valor da tensão aplicada entre seus terminais - comentou o professor.

Fez uma pausa e prosseguiu:

- Amanhã me procurem, pois tenho duas experiências interessantes. Mas, antes passem em uma loja de artigos eletrônicos e comprem um transistor BD 135.

No outro dia logo cedo, os garotos foram à busca do transistor. Por sorte, encontraram o mesmo vendedor na loja. um sorriso.

- Vocês por aqui, novamente-saudou o vendedor, com Patrícia.

- Nós viemos comprar um transitor BD 135 - disse

- Aquiestá!-exclamou ele.

- Quanto custa? - questionou Patrícia.

- Um real e cinquenta centavos - respondeu ele-Posso ajudarem mais alguma coisa?

- Pode sim - respondeu Pedro. - Será que o senhor poderia falar um pouco sobre ele, por exemplo, para que serve? De que é feito?

- O transistor é um dispositivo feito de um material semicondutor, isto é, ora comporta-se como isolante e ora comporta-se como condutor. Ele revolucionou a indústria eletrônica, pois até então, utilizávamos apenas válvulas que consomem muita energia. Além disso, elas são grandes, pesadas, frágeis e aquecem bastante.

Graças a invenção do transistor todos esses problemas foram resolvidos, aparelhos tais como, televisores, rádios, computadores etc. reduziram de tamanho, peso e o consumo de energia elétrica. Essa grande descoberta aconteceu em meados de 1940 por William Shockley (1910 - 1989), John Bardeen (1908 - 1991) e Walter H. Brattain (1902 - 1987) - explicou o senhor. Podemos considerá-lo em determinados circuitos como um resistor variável, isso significa que ora ele se comportará como condutor ora como isolante, dependendo da tensão aplicada entre a base e o emissor.

-Que?!-estranhou Tales.

- Como vocês podem perceber ele tem três pontas, chamadas de coletor, emissor e base - falava ele exemplificando com o transistor na mão.

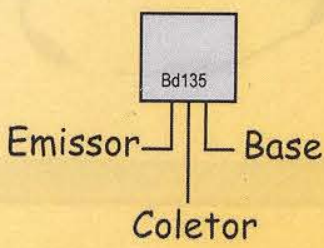

- Essas pontas devem ser conectadas adequadamente no circuito-frisou ele.

- Muito obrigado - agradeceu Pedro, após perceber que a loja estava cheia de pessoas esperando para serem atendidas.

- Sempre que precisarem de ajuda voltem pois será um prazeratendê-los-despediu o vendedor.

- Que velhinho legal! - comentou Patrícia, saindo da loja.

Dali foram direto procurar o professor na escola.

- Meus jovens! Tenho aqui duas experiências - dizia ele entregando o procedimento aos garotos. - Uma delas simula o processo de ativação das lâmpadas dos postes e a outra mostra uma aplicação do NTC. Caso vocês tenham alguma dúvida com a montagem, me chamem, eu estareina sala ao lado. 


\section{Controle de iluminação}

ATIVIDADE 10

Você vai precisar de: 2 suportes de pilhas grandes, 2 pilhas grandes de 1,5 V, 6 jacarés, 1 lâmpada de 1,2 V (pingo d'água), 1 transistor BD 135 , 1 resistência LDR (120.000 $\Omega, 300 \Omega$ ) e 1 resistência de $1000 \Omega$.

- Monte o circuito como mostra a foto. Deixe o LDR exposto à luz. Observe o brilho da lâmpada.

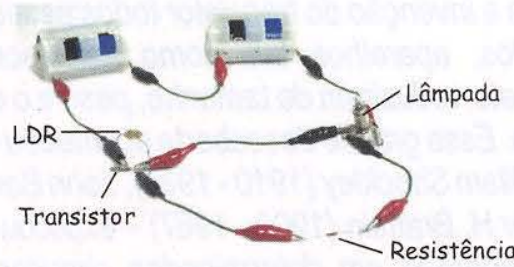

- Em seguida tampe o LDR de modo que não passe luz por ele. Observe o brilho da lâmpada.

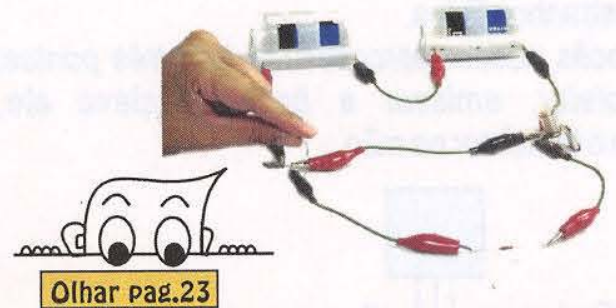

Para facilitar a montagem do circuito utilizem o esquema abaixo.

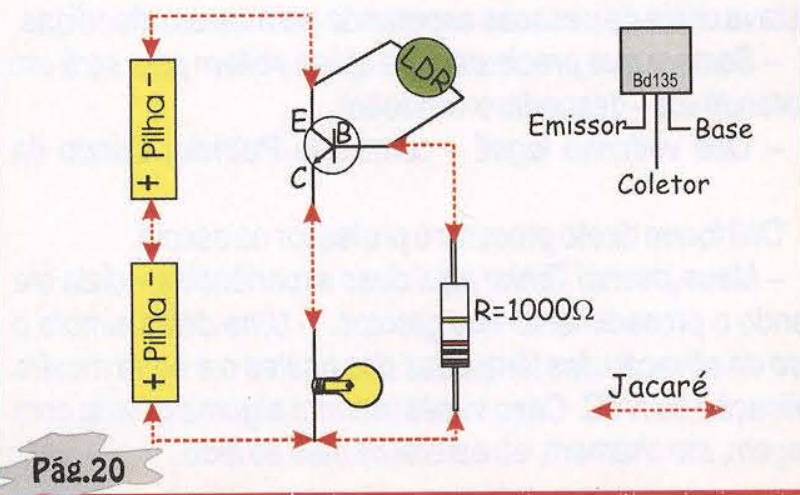

\section{Aplicação do NTC}

ATIVIDADE 11

Você vai precisar de: 2 suportes de pilhas grandes, 2 pilhas grandes de 1,5 V, 6 jacarés, 1 lâmpada de $1,2 \mathrm{~V}$ (pingo d'água), 1 transistor BD 135,1 resistência NTC $(45 \Omega, 36 \Omega), 1$ resistência de $91 \Omega$

7 - Monte o circuito como mostra a foto. Observe o brilho da lâmpada.

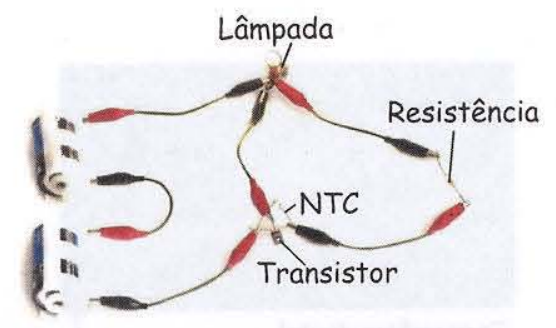

-Em seguida coloque o NTC entre os dedos. Observe o brilho da lâmpada.
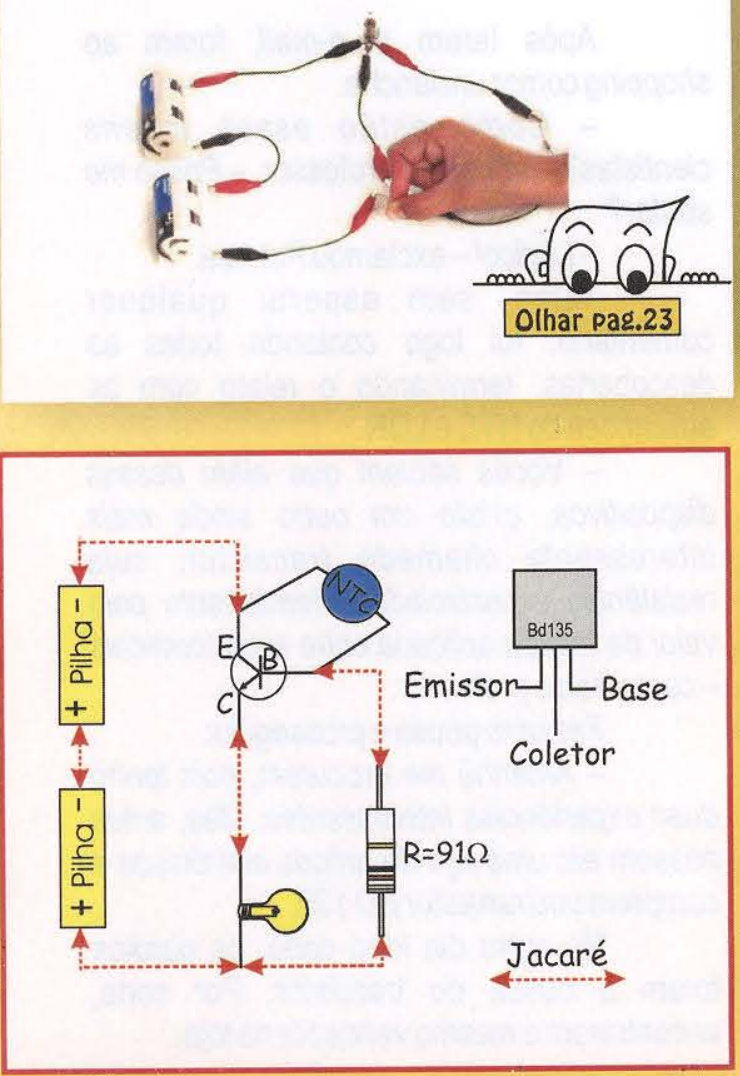
Eles montaram os circuitos, mas a lâmpada não acendia porque tinham ligado o pólo positivo da pilha ao emissor no transistor. Conferindo o esquema perceberam que o correto era ligar o pólo negativo ao emissor como está no circuito.

- Realmente, com esses circuitos podemos controlar a iluminação de um determinado local exclamou Patrícia, fazendo uma demonstração. Utilizando como exemplo, o circuito com LDR, percebemos que ao tampá-lo a lâmpada acende e, quando ele está iluminado a lâmpada apaga. Marcelo.

- Como funciona esse circuito? - questionou

Juntaram todos em torno do circuito, a fim de esclarecer a dúvida de Marcelo. Discutiram durante um tempo sobre as prováveis explicações para 0 fenômeno observado, porém não conseguiram nenhuma boa explicação, então decidiram chamar 0 professor para ajudá-los.

- Para vocês entenderem esse circuito, irei explicá-lo passo a passo - avisou o professor. Primeiramente, montem um circuito segundo esse esquema

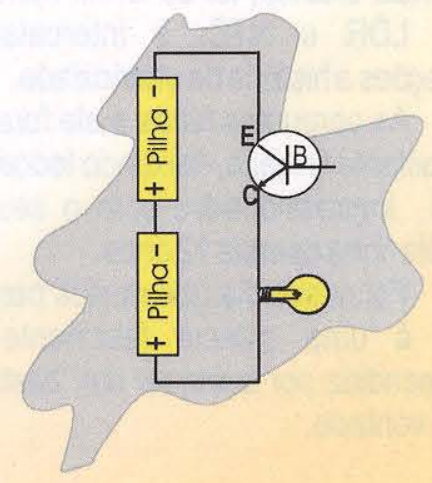
ordens do professor.

Os garotos, mais que depressa cumpriram as

- Ué! A lâmpada não acendeu - estranhou Tales.-Porquê?

- Como vocês podem perceber uma das pontas do transitor não está conectada no circuito, dessa forma, ele comporta-se como isolante, impedindo que passe corrente pela lâmpada respondeu o professor. - Para o transistor se comportar como condutor é necessário que entre a base e o emissor seja estabelecida uma diferença de potencial maior que 0,70 V. Esse valor dependerá do tipo do transistor. Agora montem o circuito como mostra o esquema seguinte- Trazendo consigo um voltímetro. E pediu que medissem o valor da tensão entre o emissor e a base do transistor com o voltímetro, em escala ligeiramente maior que $10 \mathrm{~V}$.

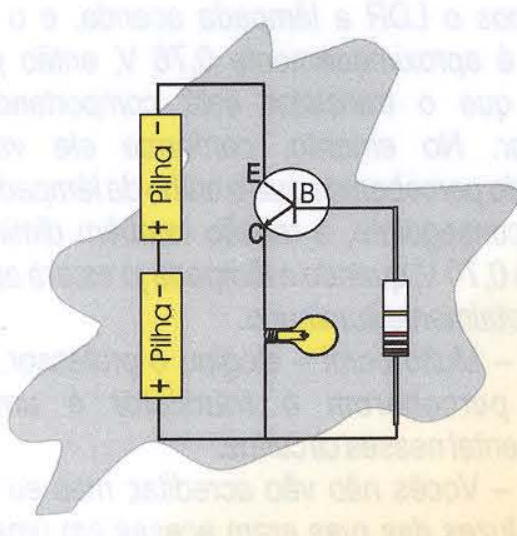

Tales.

- Agora sim, a lâmpada acendeu! - exclamou

Tales mal terminou seu comentário e Patrícia já estava medindo o valor da tensão entre o emissor e a base. Como resultado ela obteve aproximadamente 0,75 V.

- Você tinha razão - disse Pedro ao professor. É necessário que a tensão entre o emissor e a base no transistor seja maior que $0,70 \mathrm{~V}$ para ele tornar-se condutor e como fizemos isto ocorreu.

- Agora troquem a resistência de $1000 \Omega$, por uma de $470 \Omega$ e, depois por uma de $1500 \Omega$ - pediu 0 professor, entregando as respectivas resistências na mão de Patrícia.

- Olhem que interessante! - comentou Pedro. Para cada resistência, temos um brilho diferente para a lâmpada.

- Como vocês podem perceber, independente do valor da resistência, a lâmpada mantém-se acesa comentou o professor.- Mas nós queremos ela apagada quando o local estiver iluminado e acesa apenas quando estiver no escuro. É por esse motivo que o LDR é colocado no circuito. Comprovem o que eu estou dizendo, montando novamente o circuito.

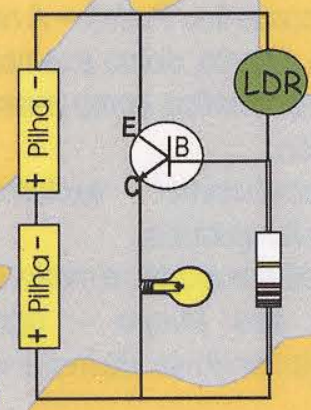

Páq.21 
- Observem! - exclamou Patrícia. - Quando tampamos o LDR a lâmpada acende, e o valor da tensão é aproximadamente $0,76 \mathrm{~V}$, então podemos afimar que o transistor está comportando como condutor. No entanto, conforme ele vai sendo iluminado percebemos que o brilho da lâmpada diminui e, por conseguinte, a tensão também diminui até 0 valor de 0,70 V, quando a lâmpada já estará apagada e o LDR totalmente iluminado.

- Muito bem! - elogiou o professor. - Como vocês perceberam o transistor é uma peça fundamental nesses circuitos.

- Vocês não vão acreditar, mas eu pensava que as luzes das ruas eram acesas em uma mesma central-falou Marcelo, sorrindo.

- Professor, para que serve o circuito que usa oNTC? - perguntou Tales, apontando para o NTC.

- Nós podemos utilizar esse circuito, para controlar a temperatura da água de um aquário. $E$, Tales mas você não deixa passar nada mesmo - disse o professor, passando a mão na cabeça do garoto.

Eprosseguiu:

É importante observar, ainda, que essa tecnologia está dominada pelos cientistas. Nesse momento, eles estão pesquisando materiais que possuam resistências elétricas nulas, chamados de supercondutores, sendo o primeiro material descoberto com essas caracteristicas em meados de 1911 por Kamerling Onnes (1853 - 1926).

Contudo, essas resistências nulas são conseguidas a temperaturas muito baixas, como exemplo, o mercúrio o qual torna-se supercondutor à uma temperatura de $-269^{\circ} \mathrm{C}$. Mas, com o avanço das pesquisas já se descobruiu materiais com resistências nulas a temperaturas mais elevadas, porém, ainda são muito baixas em torno de $-48^{\circ} \mathrm{C}$. No entanto, os cientistas, não cessam suas pesquisas, e o grande desafio é descobrir um material que possua resistência nula à temperatura ambiente, pois assim, o transporte de energia elétrica ocorreria sem perdas por calor na resistência.

- Diante disso, eu cheguei a seguinte conclusão - comentou Pedro. - A resistência ora é um incomodo no circuito, como exemplo, o transporte de energia e ora é benéfica, como vivenciamos no caso do $L D R$, transistor...

- Corretíssimo! - exclamou o professor. Espero então ter ajudado.

- Você nos ajudou e muito, mas não queremos tomar mais seu tempo - agradeceu Patricia,

Páq.22
Saíram de lá encantados com as novas descobertas e foram direto para a lanchonete comemorar.

No dia seguinte, a professora de ciências de Tales, pediu para cada aluno escolher um tema a ser apresentado na feira de ciências da escola. Ele sem pensar, decidiu por "eletricidade". A professora achou estranho aquele título, afinal era um contéudo complicado para um garoto de 12 anos, mas não se colocou objeção.

Na primeira reunião Tales contou a novidade aos colegas, que o apoiaram de imediato.

- Você pode apresentar todas as experiências que fizemos de eletricidade... - disse Pedro, empolgado com a notícia.

Todos gostaram da idéia e começaram logo a colocá-la em prática.

Passaram-se 15 dias, e o dia tão esperado havia chegado.

O trabalho de Tales foi um sucesso, sendo um dos mais visitados por estudantes e professores. Ele, muito vaidoso, explicava com demonstrações 0 que é: corrente elétrica, diferença de potencial, resistência elétrica, lei de Ohm, resistores variáveis como: LDR e NTC, e intercalando entre as explicações a história da eletricidade.

As perguntas feitas a ele foram respondidas com bastante firmeza, deixando todos que passavam por ali impressionados com o seu desempenho, afinal ele tinha apenas 12 anos.

Foi nesse dia que muitos perceberam que a Física é uma ciência fascinante e pode ser compreendida por qualquer um, basta ter um pouco de boa vontade. 


\section{Lista de materiais}

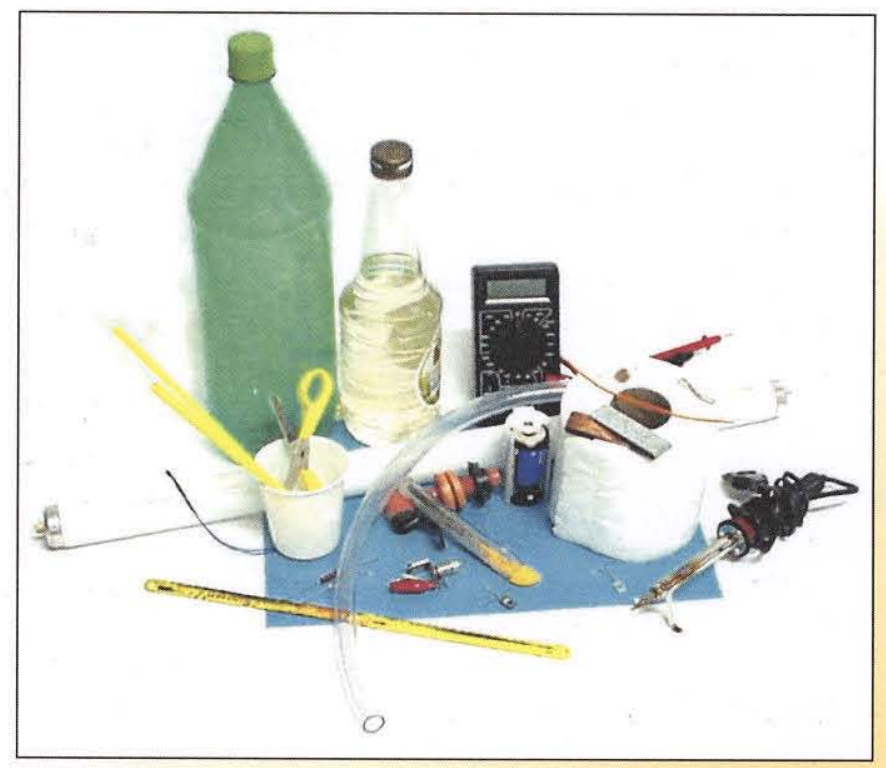

Na foto acima estão todos materiais necessários para a realização das atividades propostas nesse fascículo. Primeiramente faremos algumas recomendações quanto ao uso deles e depois, quando possive,l iremos propor outros materiais.

1- Os seguintes materiais: estanho, garras tipo jacaré tamanho pequeno, soldador, pilha, resistência, multimetro led(vermelho), lâmpada, soquete, LDR, NTC e transistor Bd135 são encontrados em lojas de artigos eletrônicos.

2- Chapas de cobre e zinco são encontradas em lojas que vendem calhas ou lojas de materiais ferrosos. É importante dizer que as chapas de zinco possuem apenas uma camada de zinco.

3-Deve-se ter muito cuidado com o transistor pois seus fios são frágeis e se quebram facilmente.

4- Eu recomendo utilizar os multímetros digitais porque os mais baratos possuem uma boa precisão; ao contrário dos multímetros analógicos.

5- Sempre que vocês estiverem trabalhando com amperímetro, liguem-o na escala $10 \mathrm{~A}$, para evitar que 0 aparelho estrague, caso haja uma corrente alta no circuito. 


\section{Blackout}




\section{Caro Leitor}

A motivação desse trabalho é fornecer um material que estimule você, leitor, a conhecer os fascínios da ciência. Para isso, estamos apresentando com naturalidade, por intermédio de experimentos simples, inseridos numa narrativa ficcional, alguns conceitos complicados, sempre que possível associando-os ao cotidiano .

Esse livro é recomendado tanto para leigos, a partir de 12 anos, quanto para profissionais da área. Queremos deixar claro que a leitura do mesmo não dispensa o acompanhamento de um livro didático para um aprendizado mais formal.

0 conteúdo do livro é apresentado por meio de questionamentos que os personagens fazem entre si $e$, quando não conseguem resolvê-los por si só, procuram um site, que conduzirá toda a hisłória, sempre respondendo o necessário e propondo atividades com as quais serão esclarecidas todas as dúvidas. A história da eletricidade é apresentada no decorrer do texto pelos próprios personagens. Todos os experimentos propostos utilizam materiais simples e de baixo custo que foram rigorosamente testados afim de estimular o interesse do leitor pela ciência.

Para um melhor aproveitamento do conteúdo do livro é recomendado que as atividades sejam efetuadas na ordem que são sugeridas.

Utilizamos a figura para simbolizar que o experimento necessiła da presença de um adulto, pois são atividades que podem trazer danos à integridade física do leiłor. Já o símbolo

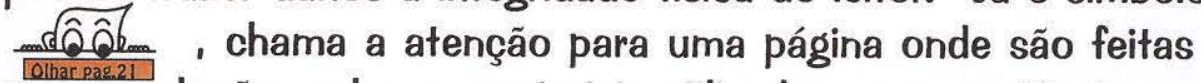
recomendações sobre os materiais utilizados nas experiências e quando possivel a substituição dos mesmos.

Nesse fascículo você construirá um motor elétrico, aprenderá o princípio de funcionamento do cartão magnético entre outros fenômenos. Por isso, convidamos você, caro leitor, a viajar por esse mundo do eletromagnetismo.

\section{Vamos???}




\section{Blackout}

Setembro, os preparativos para festa de aniversário de Tales estão a mil. O tão esperado dia havia chegado.

- Mãe, que horas são? perguntou Tales, ansioso pelo começo de sua festa de aniversário.

- Não se preocupe, ainda faltam 2 horas para os convidados chegarem - respondeu ela. - Porém, acho bom você irtomarbanho.

- Tábom! disse Tales, resmungando.

Quando ele estava quase terminando seu banho, a energia elétrica em sua casa foi interrompida. Tales, desesperado, por achar que sua festa teria ido por "água a baixo", só se acalmou com a noticia que tudo voltaria ao normal em breve. Algum tempo depois os convidados começaram a chegar para a festa. Todos estavam muito animados.

- Pedro! -exclamou Marcelo. - Eu achei muito legal o presente que você deu ao Tales.

- Na verdade, foi uma sugestão do meu pai. Ele disse que seria muito útil para as nossas experiências respondeu Pedro.

- Posso saber do que vocês estão falando? - Patrícia, uma amiga do grupo, intrometeu-se na conversa.

- Do multímetro!-respondeu Tales, feliz com o presente dado por Pedro.

- Pela cara de contente, nem preciso perguntar se você gostou?

- Realmente, Pat, eu adorei - falou Tales. - Vocêsnão vão acreditar, quase não houve festa!

- Quê!? - disseram todos ao mesmo tempo.

- A energia elétrica acabou pouco antes dos convidados chegarem -explicou ele.

- Porquê?-questionou Pedro. irmão de Tales.

- Um funcionário da companhia de energia elétrica disse que foi um problema no gerador-antecipou-se Marcelo,

- Oque é um gerador? - estranhou Tales, com um ponto de interrogação na testa. - Seria uma grande pilha?

- Não é uma bateria - respondeu Marcelo. - Mas eu não sei explicar como ele funciona.

- Pessoal! - disse Patrícia, irritada com aquela conversa. - Vamos curtir a festa! Eu fiz um trabalho sobre usinas elétricas, amanhã eu mostro para vocês verem.

Todos concordaram. Ela sorriu e saiu para buscar um refrigerante.

- A Pat está linda! - comentou Pedro encantado.

Marcelo e Tales começaram a caçoar dele que tentou argumentar;

- Faleiporfalar. Vocêsé que imaginam coisas!

No dia seguinte, lá estava ela com o trabalho em mãos. Tales rapidamente começou a lê-lo em voz alta.

- Há vários tipos de usinas elétricas, tais como:

Usina Hidroelétrica: a maior parte da energia elétrica, no Brasil, é gerada em usinas hidroelétricas porque possuímos uma enorme quantidade de rios. Essa energia é produzida da seguinte forma: a queda d'água move as pás de uma turbina, que por sua vez, aciona o gerador, o qual transformará energia mecânica, fornecida pela queda d'água, em energia elétrica, como mostra a figura.

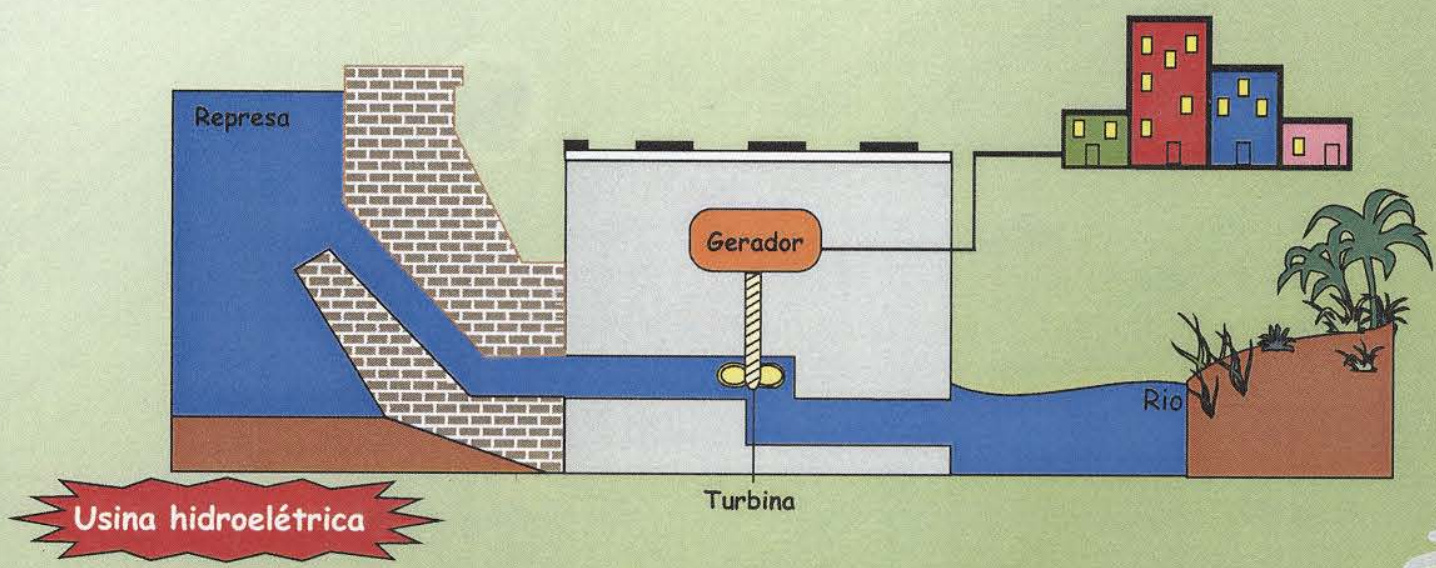


Algumas desvantagens:

- As hidroelétricas dependem de chuvas para terem seus niveis regularizados.

- A formação dos reservatórios em geral prejudica o meio ambiente afetando a fauna e a flora.

Usina Termoelétrica: as termoelétricas possuem uma caldeira com água, que é aquecida através da queima de um combustível: gás natural, óleo, carvão mineral ou residuos vegetais, produzindo vapor d'água a alta pressão, o qual mantém as turbinas em movimento e, por conseqüência, o geradorque produzirá a corrente elétrica.

Vale lembrar, ainda, que nesse sistema a energia térmica, proveniente da queima do combustivel, é transformada em energia mecânica e posteriormente em energia elétrica. Oesquema abaixo mostra osprocessos citados acima.

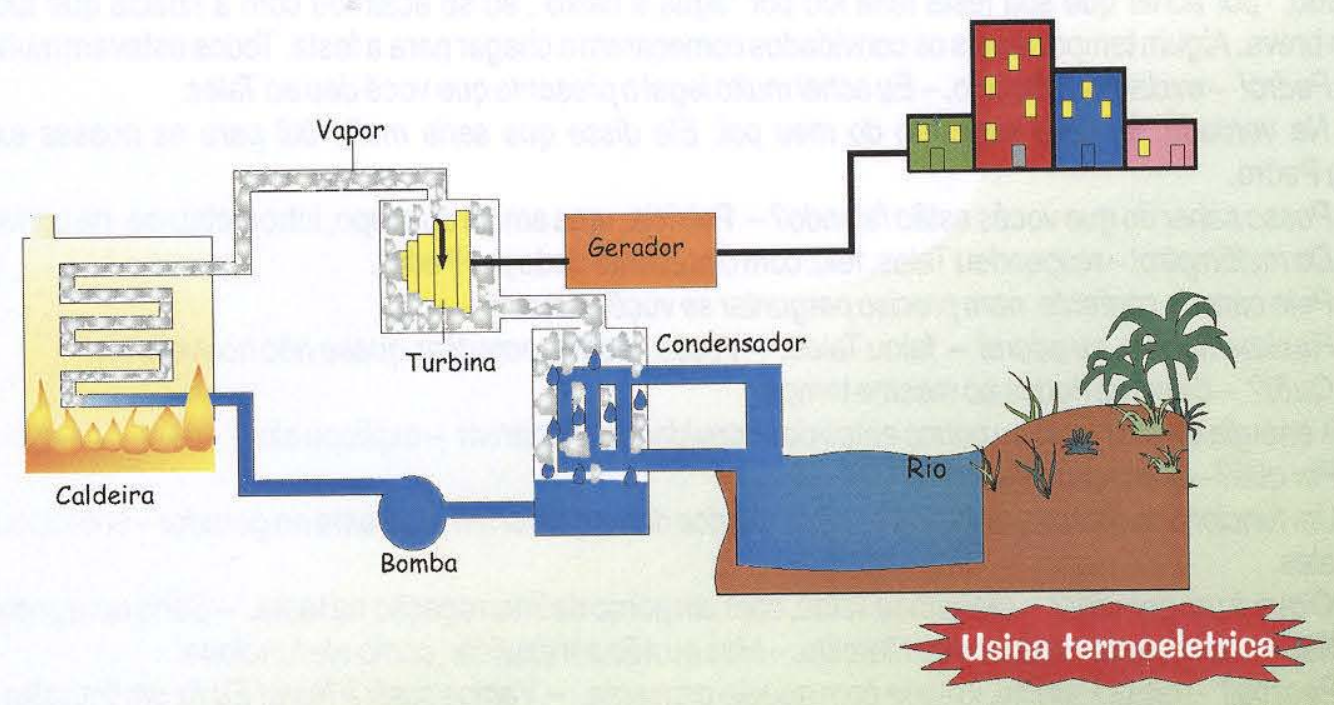

Desvantagens:

- Liberação de gás poluente para a atmosfera, provocando sérios problemas respiratórios na população residente nas vizinhanças da usina termoelétrica.

- Formação de chuvas ácidas que causam danos em florestas, plantações, lagos, peixes, prédios, água de abastecimento, etc, e, como aumento da acidez da terra, os recursos de alimentação e produção diminuem.

- As usinas termoelétricas devolvem ao rio água muito quente, a qual écapaz de destruir a sua fauna e flora.

Usina Nuclear: em um reator ocorre a fissão nuclear, isto é, a divisão de um átomo de urânio, por bombardeamento de nêutron. Após esta quebra há uma enorme liberação de energia.

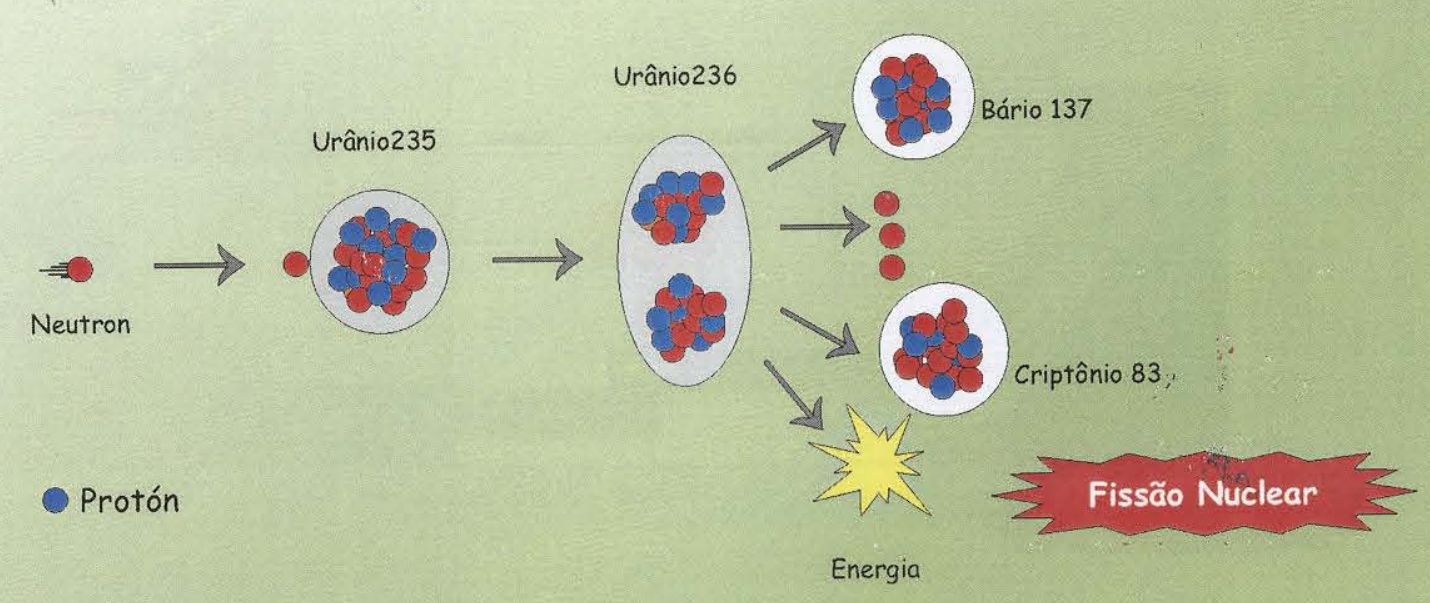


A energia liberada pela fissão nuclear (quebra) aquece a água produzindo vapor d'água a alta temperatura. 0 vapor aciona uma turbina ligada ao gerador, o qual transforma energia mecânica fornecida pela turbina em energia elétrica.

Cabe observar que, os processos de transformações de energia na usina nuclear são semelhantes aos ocorridos na usina termoelétrica, diferem apenas no agente responsável pela produção energia térmica, no caso da termoelétrica é pela queima de um combustivele, na usina nuclear pela fissão nuclear.

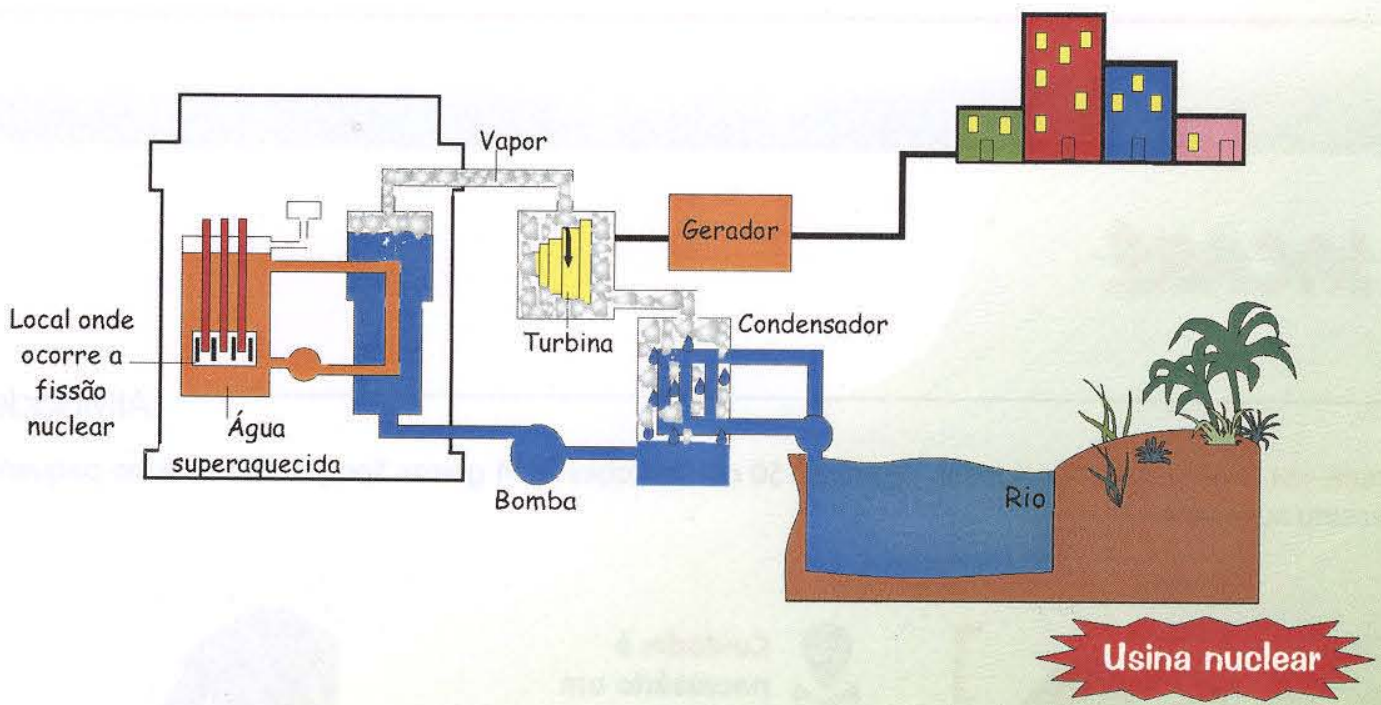

\section{Desvantageins:}

- Uma usina nuclear necessita parar após um ano de uso para a recarga do reator e leva uns 45 dias em média para retornara operação.

- Olixo nuclear produzido pelos destroços da fissão nuclear, causa problemas sérios para o meio ambiente.

- Ela encerrará suas atividades entre 25 a 30 anos de uso, porque o nivel de radiação no prédio do reator atingirá niveis prejudiciais à saúde de empregados responsáveis pela sua operação.

Existem outras usinas elétricas, tal como a usina eólica, cujo principio de funcionamento é o mesmo das hidroelétricas, havendo apenas a troca da água pelo vento, na produção da rotação das turbinas.

É importante enfatizar que o homem não é capaz de criar ou destruir energia, ele apenas desenvolve máquinas que a transforma.

- Muito bem! - elogiou Pedro, após a leitura de Tales. - Mas, ficou uma dúvida: como funciona o gerador?

- Eu não sei - respondeu ela. - Vamos enviar um e-mail para o site, "Luiz Antônio Responde", que esclarece dúvidas de ciências. Primeiramente contaremos o que sabemos sobre as usinas elétricas e depois perguntaremos como funciona o gerador.

- Perfeito! - exclamou Marcelo. - Mandareio e-mail, agora.

Garotos! Gerador de eletricidade é uma máquina que converte energia mecânica em energia elétrica, sendo a peça fundamental das usinas elétricas. 
A título de ilustração estou enviando uma atividade que demonstrará UIzตกTôno processos de transformações de energia. Mas, para a melhor compreensão dos processos de transformação de energia, proponho que vocês construam alguns materiais necessários para o desenvolvimento da atividade. E, a propósito, parabéns pelo aniversário Tales!

\section{JACARÉ}

Atividade 01

Você vai precisar de: 1 soldador, estanho, $50 \mathrm{~cm}$ de cabinho, 14 garras tipo jacaré tamanho pequeno e tesoura ov estilete.

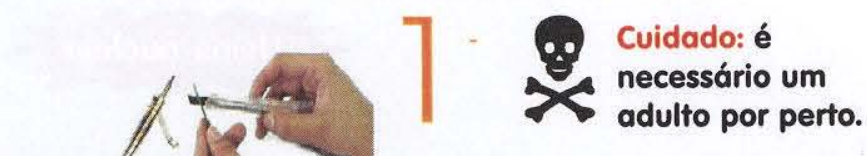

Primeiramente, leia atentamente 0 manual de instruçōes do soldador. Após feito isso, ligue o soldador. Depois corte, com a tesoura, 7 pedaços de cabinho de $10 \mathrm{~cm}$ cada. Em seguida desencape $0,5 \mathrm{~cm}$ de cada lado do cabinho.

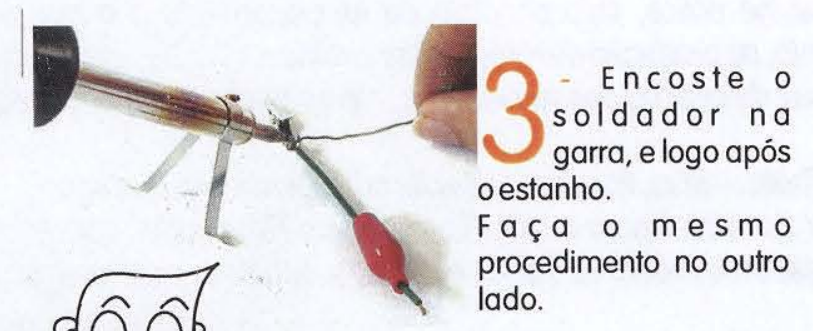

a ça mesmo ado.

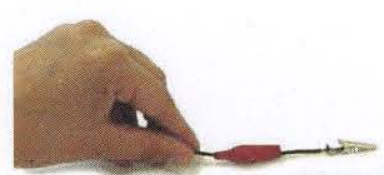

- Enfie 1 capinha em cada um dos lados do cabinho. Coloque a porção desencapada do cabinho na parte maior da garra.

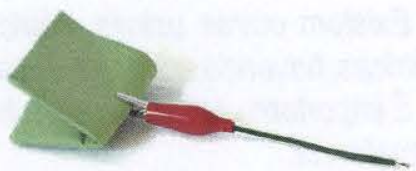

Espere uns dois minutos, até o estanho e a garra esfriarem.

Coloque a capinha na garra. Façam 3 jacarés.

Perigo! É necessário muito cuidado com o soldador, quando em contato com a pele causará queimaduras graves, porque sua temperatura atinge $300^{\circ} \mathrm{C}$. Para maior segurança, peça para um adulto soldar os cabinhos nas garras. 
- A pilha é um ótimo exemplo - disse Pedro, em frente da tela do computador.

Os garotos não entenderam 0 comentário, mas preferiram não prolongar a conversa porque estavam ansiosos para montar a pilha.

- Agora eu entendo porque você achou

\section{Atividade 02}

Você vai precisar de: 2 chapas de cobre, 2 chapas de zinco, 2 copos de plástico de $180 \mathrm{ml}$, 1 led (vermelho), coca-cola, 3 jacarés.

Coloque uma chapa de zinco e uma de cobre em cada copo. Em seguida, encha-os com coca-cola.
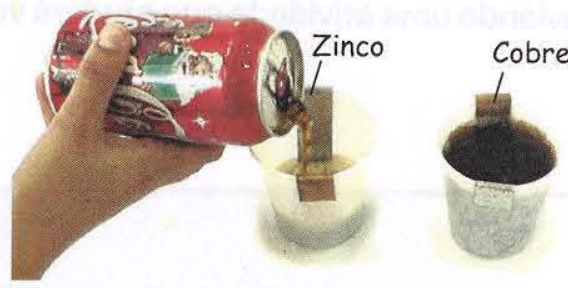

( )

igue as chapas de zinco e cobre utilizando o jacaré.

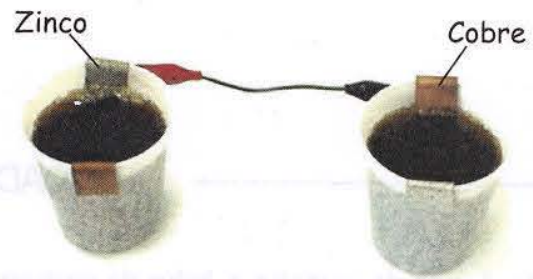

-Ligue uma chapa de zinco, 1 led e uma chapa de cobree com osjacarése observeo led.

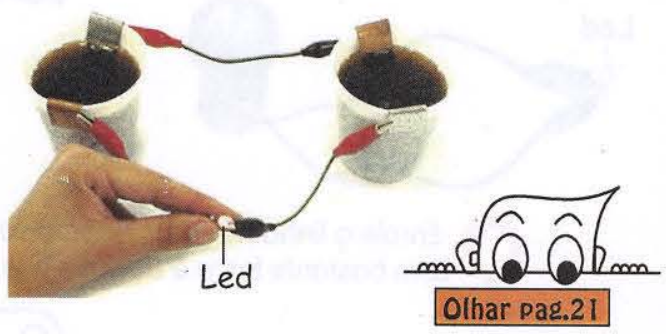
a pilha uma boa sugestão - disse Patrícia, olhando para o led aceso. - Afinal, a energia química produzida pelas reações químicas ocorridas entre as placas e a coca-cola, foi transformada em energia elétrica, acendendo 0 led.

- Muito bem, garota! - elogiou Pedro.

- Será que vocês poderiam responder o que é um led? - falou Tales, irritado com a falta de atenção dada a ele, pelos colegas.

- Não fique enciumado - brincou

Pedro. - Coincidentemente, ontem eu estava lendo um livro sobre esse assunto. Led é a sigla de "Light Emiting Diode", quer dizer diodo emissor de luz. Eles são confeccionados com materiais semicondutores.

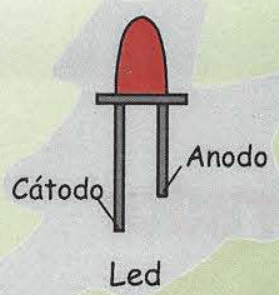

- Existe um detalhe a ser falado, como você pode perceber, ele possui uma ponta maior, chamada de cátodo. Ela deverá ser ligada à placa de cobre, isto é, ao pólo positivo da sua pilha, conseqüentemente, a ponta menor, chamada anodo, deverá ser ligada à placa de zinco, ou seja, ao pólo negativo. Por isso, é dito que ele possui polaridade ou seja, o led conduz corrente elétrica apenas em um sentido, diferentemente da lâmpada. E mais, o led possui a vantagem de transformar em luz, quase toda energia fornecida a ele, ao contrário da lâmpada incandescente, onde grande parte da energia é perdida na forma de calor.

प्रु Maiores detalhes podem ser obtidos no livro "As aventuras de Pedro".

Pác.05 
- Mas e o gerador? - perguntou Patrícia, após a explicação de Pedro.

- É mesmo, nos empolgamos com a pilha e acabamos nos esquecendo da dúvida inicial - disse Marcelo. Vamos escrever para o site contando nossas observações e terminamos perguntando novamente como funciona 0 gerador.

Todos acharam uma boa idéia e, enquanto esperavam a resposta do professor Luiz Antônio, Pedro contou uma última curiosidade, para encerrar o assunto sobre transformação de energia.

- Pessoal! Energia não pode ser criada nem destruída, nós podemos apenas transformá-la, de um tipo em outro. Esta é a lei da conservação da energia e, já foi verificada várias vezes pelos cientistas - concluiu Pedro, repetindo as palavras de sua professora.

- Chegou o e-mail do professor! - gritou Marcelo, ao ouvir o barulho que anuncia a chegada de novas mensagens.

Parabéns, garołos! As suas conclusões estão correłas. Quanto ao

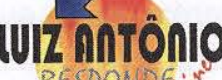
RESPON E a entendê-lo.

funcionamento do gerador, esłou enviando uma atividade que ajudará vocês

\section{Gerador}

Você vai precisar de: 1 motor elétrico, 1 led vermelho, 2 jacarés, 1 roda de carrinho e linha de costura.
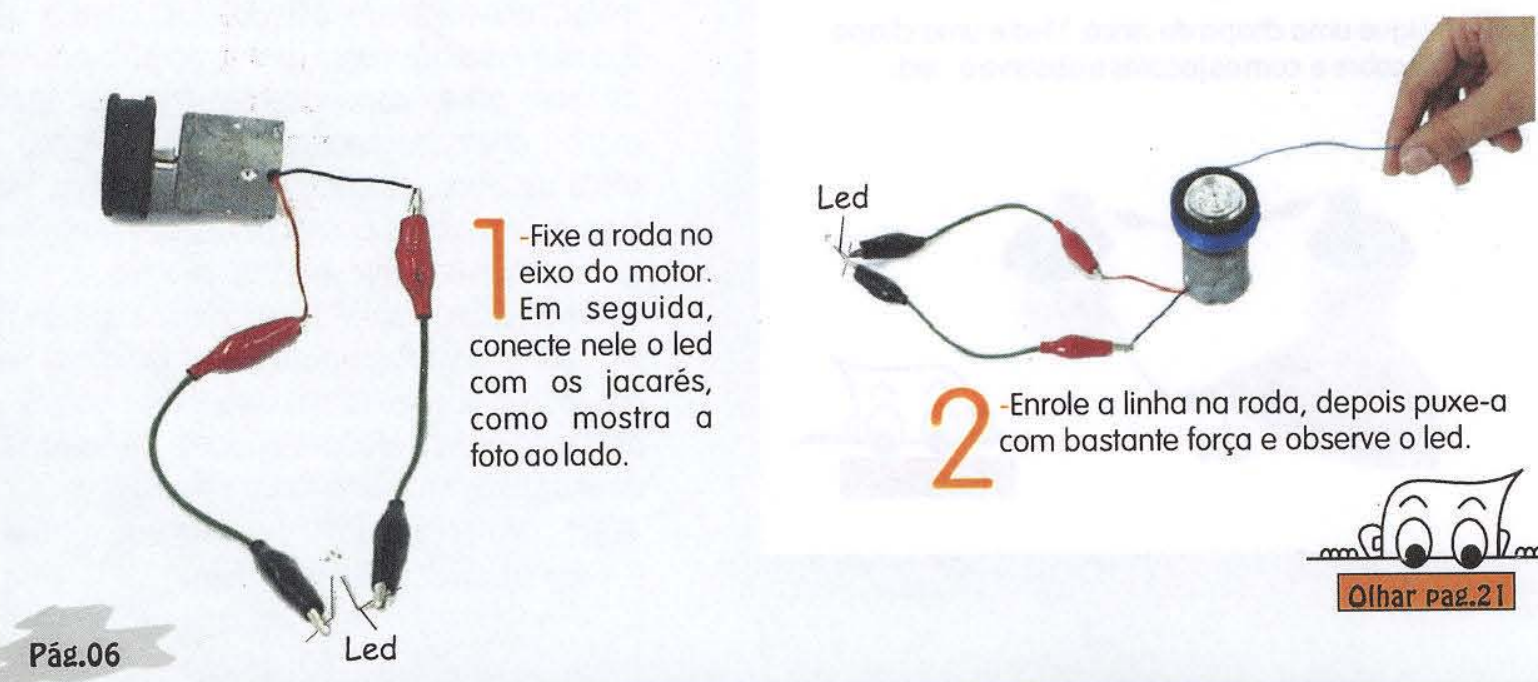

-Enrole a linha na roda, depois puxe-a com bastante força e observe o led.

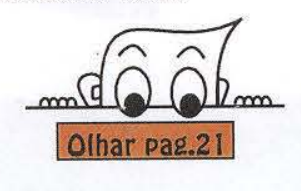


- Já sei! Nós podemos pegar o motor do meu carrinho - avisou Tales, saindo correndo.

Pouco tempo depois, lá estava ele com o carrinho desmontado e o motor na mão.

- Olhem! Quando giramos a roda, o led acende demonstrou Pedro, após montar o gerador. - Isso mostra uma transformação de energia mecânica em energia elétrica.

- Não estou entendendo mais nada - disse Patrícia, com a mão na cabeça. - Qual a diferença entre motore gerador?

Logo em seguida, Tales perguntou. não consegui.

- O que tem dentro do motor? Já tentei abrí-lo mas

- Não vejo outra alternativa, a não ser enviar umemail para o Luiz Antônio contanto nossas observações e perguntando qual é a diferença entre gerador e motor, em seguida perguntamos o que tem dentro desse motor sugeriu Pedro.

Todos concordaram e Marcelo enviou o e-mail.

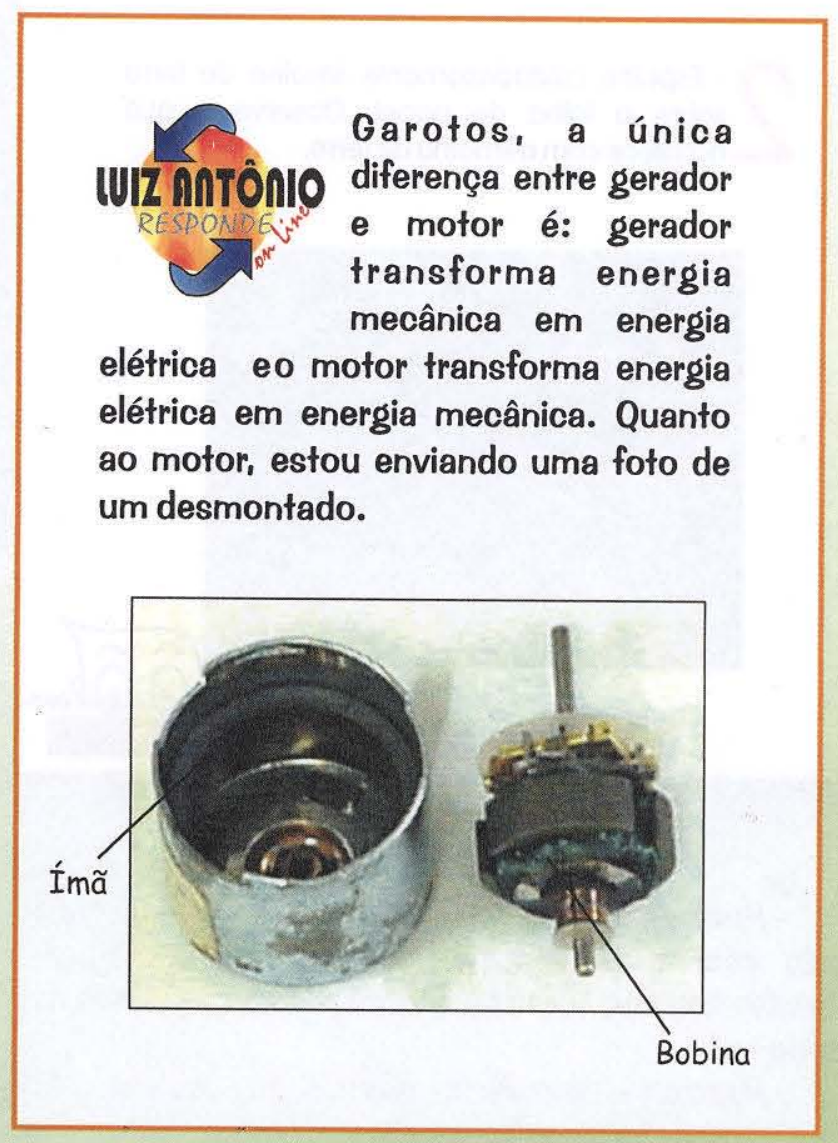

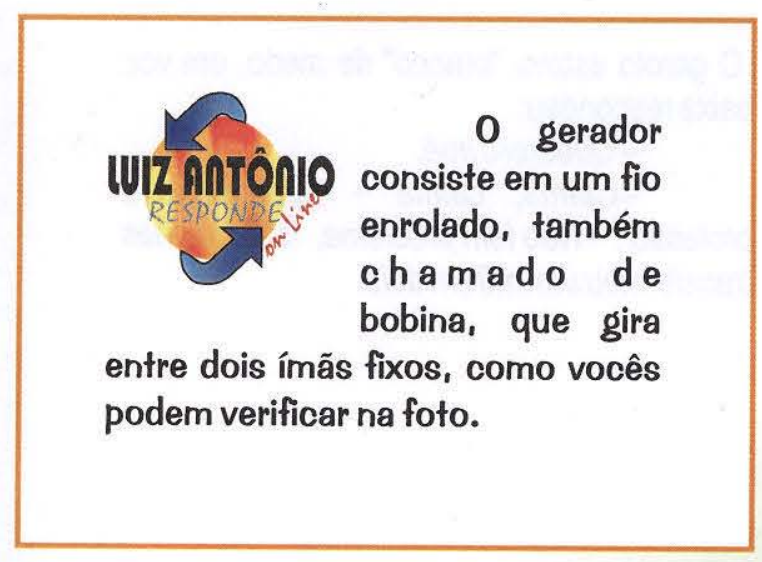

- Não entendinada! - exclamou Tales.

- Eu também não - disse Pedro. Poderíamos procuraro professor Mário e pedir ajuda, o que acham?

Todos concordaram e lá foram eles em busca do professor. Os garotos tiveram que esperálo terminar uma aula.

- O que aconteceu para esses jovens virem até a escola, numa sexta-feira à tarde? - brincou ele.

Os garotos começaram contando todos os questionamentos ocorridos na festa de Tales, depois mostraram a foto enviada pelo site e finalizaram perguntando como funciona o gerador.

- Por coincidência estou indo preparar uma aula de laboratório sobre esse assunto - disse 0 professor.-Sigam-me!

Ao chegar no laboratório, o professor pegou; imã, limalha de ferrol e papel sulfite em um armário e colocou-os em cima da mesa. Tales, muito inquieto, começou a brincar com o ímã, quando de repente deixou-o cair. Ao vê-lo partido ao meio, se desesperou. Marcelo, acostumado com as travessuras do irmão, percebeu algo errado e foi verificar.

- Tales, o que você aprontou dessa vez? 
O garoto estava "branco" de medo, em voz baixa respondeu:

-Quebreioímã.

-Calma, calma - apaziguou o professor. - Não tem problema, Tales apenas transformou um ímã em dois.

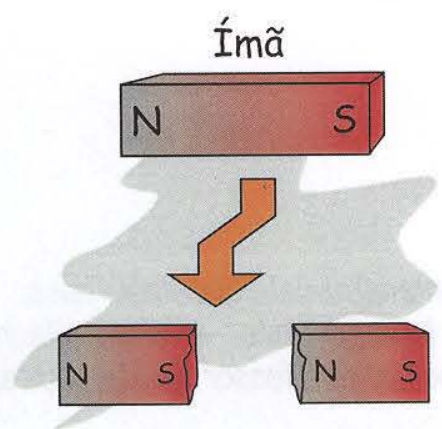

A cor vermelha representa o pólo norte e a cinza o pólo sul do ímã.

- Quê!? exclamou Patrícia.

- Tales apenas redescobriu o que foi observado há 800 anos atrás por Petrus Peregrinus de Maricourt (1240 - ?), um grande pesquisador de imãs naturais - explicou ele.

- Professor, afinal qual é a função do ímã no gerador? - questionou Patrícia, ansiosa para entender o princípio de funcionamento do gerador.

Prefiro não dizernada por enquanto. Façam essa experiência - disse o professor, entregando o roteiro e os materiais necessários.

Páq.08

\section{Linhas de Campo}

ATIVIDADE 04

Você vai precisar de: Limalha de ferro, 1 ímã e 1 folha de papel sulfite.

- Coloque o ímã embaixo e no centro da folha de papel.

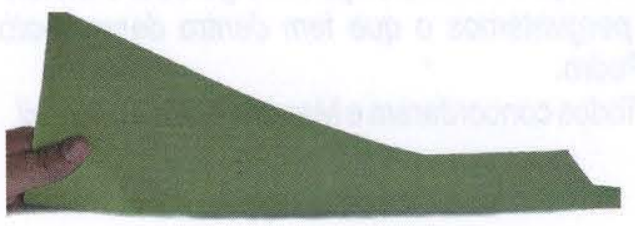

$=$

- Espalhe cuidadosamente limalha de ferro sobre a folha de papel. Observe o que acontece com a limalha de ferro.

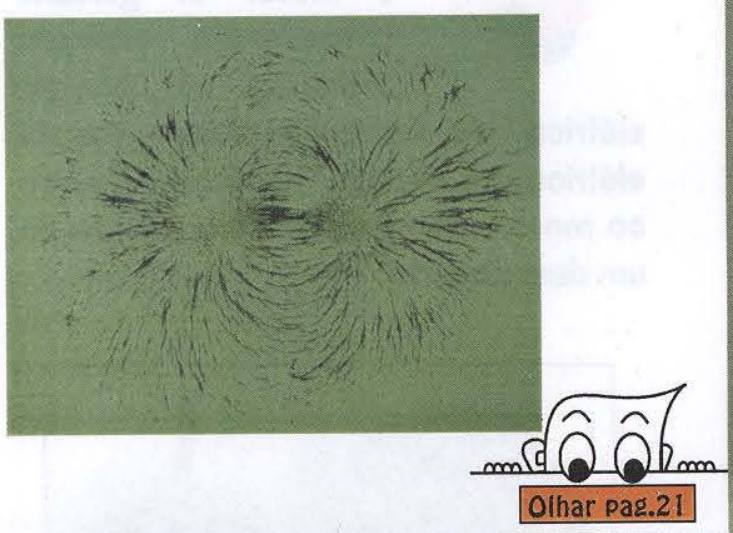

- Puxa que legal! - exclamou Tales, ao ver o desenho formado com a limalha de ferro no papel.- Mesmo movimentando o ímã, a limaha continuam se acumulando nas pontas do ímã.

- Reparem - disse Pedro, fazendo um esquema. 


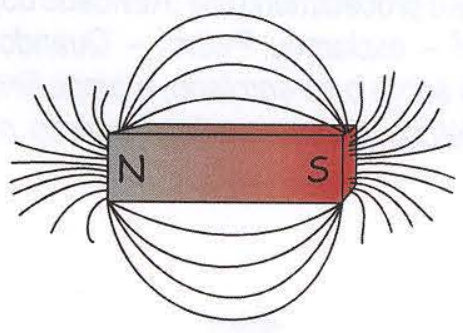

Representação das linhas de campo magnético de um ímã.

- Como podemos notar, as linhas saem de uma ponta do ímã e entram na outra-continuou ele.

- Por que as linhas se acumulam nas extremidades do ímã? - perguntou Patrícia.

0 professor, que até então estava apenas observando a conversa dos garotos, resolveu intervir.

- O acúmulo da limalha de ferro nas extremidades do imã indica que 0 campo magnético é mais intenso nessas regiões.

- Campo magnético! estranhou Patrícia. - Oque éisso?

- Campo magnético é um campo de força que existe ao redor do imã, que atua provocando uma força de atração sobre elementos que contêm ferro, aço, cobalto ou níquel (sozinhos ou combinados). Essa figura formada com a limalha de ferro é chamada linhas de campo magnético, sendo elas uma forma imaginária de representá-lo lembrou ele. - São justamente essas linhas de campo magnético, que induzem corrente elétrica no gerador. Para vocês comprovarem esse fato, façam a seguinte experiência.

\section{Experiência de Faraday}

ATIVIDADE 05

Você vai precisar de: 2 jacarés, 1 prego grande de $6 \mathrm{~cm}$ de comprimento aproximadamente, fio de cobre $\mathrm{n}^{0} 37$, 1 imã, 1 amperímetro e 1 estilete.

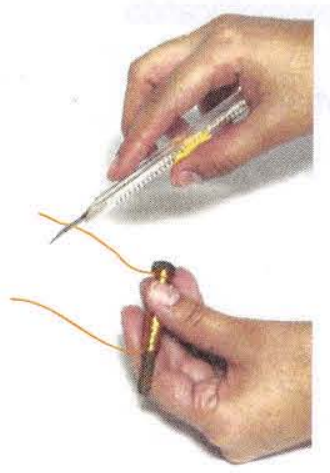

- Enrole em torno do prego
aproximadamente 400
voltas de fio de cobre $n^{\circ} 37$, deixando duas pontas de $10 \mathrm{~cm}$. Raspe com um estilete $1 \mathrm{~cm}$ de cada extremidade do fio.

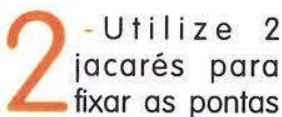
do fio de cobre no multímetro. Use o amperímetro com fundo de escala ligeiramente maior que $10 \mathrm{~mA}$.

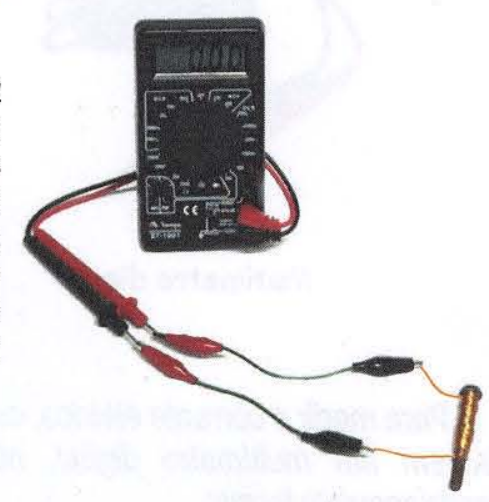

- Passe o ímã sobre o prego, fazendo um movimento de ida e volta sem encostá-lo no fio de cobre. Observe ovisor do amperimetro.

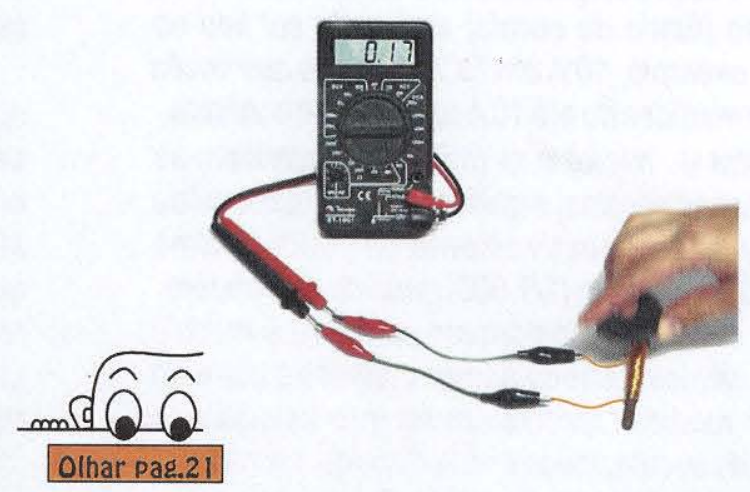


- Tales, venha ver um amperímetro digital igual ao seu - gritou Marcelo, chamando o irmão que estava distraído procurando na sala os objetos que eram atraídos pelo ímã.

- É verdade! - exclamou Tales. - Professor esse aparelho também é chamado de multímetro, não é?

- Você tem razão - concordou o professor. Esse aparelho pode ser usado para medir corrente elétrica, diferença de potencial e resistência elétrica. Mas, hoje, o utilizaremos apenas para medir corrente elétrica. Devo alertá-los, ele é muito sensivel, por isso deve-se tomar muito cuidado, porque qualquer descuido poderá estragá-lo. - E ele prosseguia exemplificando como multímetro na mão.

䟚 Maiores detalhes podem ser obtidos no livro "As aventuras de Pedro".

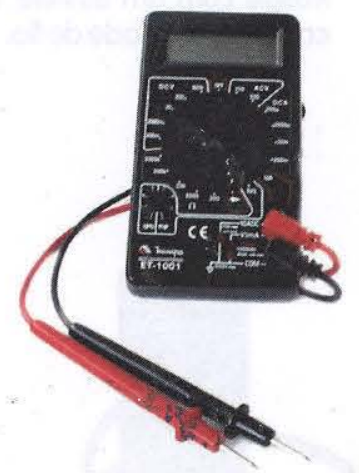

Mutímetro digital

- Para medir a corrente elétrica, cuja unidade é Ampère, em um multímetro digital, nós devemos proceder da seguinte forma:

Primeiro selecionaremos com o botão que está ao centro com uma seta, a escala DCA (Direct Current Ampére), isto é, corrente contínua. Os valores que aparecem em cada posição do botão seletor informamo valor máximo (fundo de escala) que pode ser lido no display. Por exemplo, 10 A em DCA significa que vocês podem fazer medidas de até $10 \mathrm{~A}$ em corrente contínua.

A letra $\mu$ micro) e $m$ (mili) que encontram-se junto de algumas escalas, significam que o número lido no display é respectivamente a milionésima (1/1.000.000) e milésima (1/1.000) parte de um Ampère.

Um outro aviso importante se refere à medida da corrente elétrica: quando não se conhece a corrente que irá ser medida, recomenda-se que selecione o maior fundo de escala, meça e vá reduzindo a escala até obter leitura apropriada. E, também, nunca

Pác.10 ligue o amperímetro na tomada.
Agora pessoal, façam o que está sendo proposto - pediu o professor, apontando para uma folha onde estava o procedimento da (Atividade 05).

- Olhem! - exclamou Pedro. - Quando eu movimento o ímã sobre o fio enrolado, o amperímetro acusa corrente elétrica, porém se o deixo parado, nada acontece.

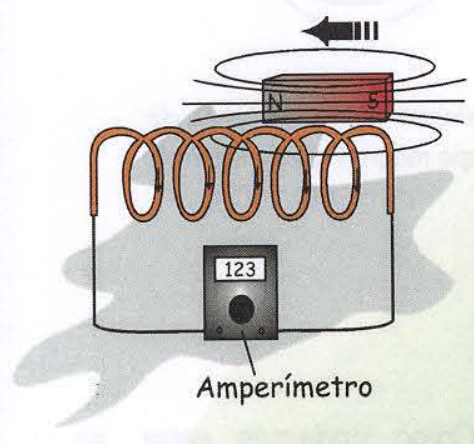

- Mas no gerador o ímã está parado - avisou Marcelo.

- Você tem razão - concordou Pedro. Simples, vamos deixar o ímã parado e movimentar apenas a bobina, para ver o que acontece.

- Parabéns, garoto esperto - brincou Marcelo. - Afinal, essa montagem também gera corrente elétrica, pois basta o movimento relativo entre o ímã $e$ abobina.

- Professor, quem descobriu esse fenômeno? - perguntou Patrícia, enquanto os garotos brincavam como ímãe abobina.

- O responsável por essa descoberta foi Michael Faraday (1791 - 1867) - disse o professor. Ele nasceu em uma familia humilde, era o terceiro filho de um ferreiro. Aos treze anos de idade foi obrigado a largar os estudos. Por sorte, foi trabalhar com um livreiro, que the ensinou a arte de encadernar e, também Ihe facilitou o acesso aos livros.

Dai por diante, Faraday aproveitou todas as oportunidades que surgiram em sua vida, e fez descobertas brilhantes, como essa que vocês observaram. Mas não pensem que elas foram obtidas facilmente, necessitou muita persistência e dedicação, qualidades essas que o tornaram um pesquisador reconhecido mundialmente e membro, na época, de uma instituição de que só os grandes cientistas faziam parte, chamada "Royal Institution da GrãBretanha". 
Eele prosseguia:

- Garotos, no encerramento das minhas aulas eu costumo mostrar uma aplicação tecnológica. No caso do ímã, além do gerador, mostrarei como aplicação a bússola - falava o professor, mexendo em um armário.

Ah! Aqui está o procedimento - disse o professor, entregando um papel nas mãos dos garotos.

- Uma bússola, que legal! - disse Tales, ao ler o nome da experiência.

\section{Construção de uma bússola}

\section{ATIVIDADE 06}

Você vai precisar de: 1 agulha de costura, 1 pires, 1 pedaço de rolha, imã, fita adesiva e água.

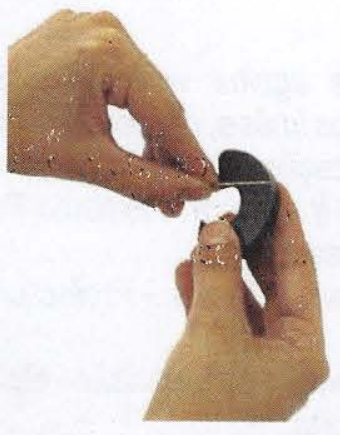

- Faça uma marca em uma das pontas da agulha. Depois magnetize a agulha passando o ímã ao longo dela por alguns minutos.

- Fixe a agulha no
rolha com fita adesiva.
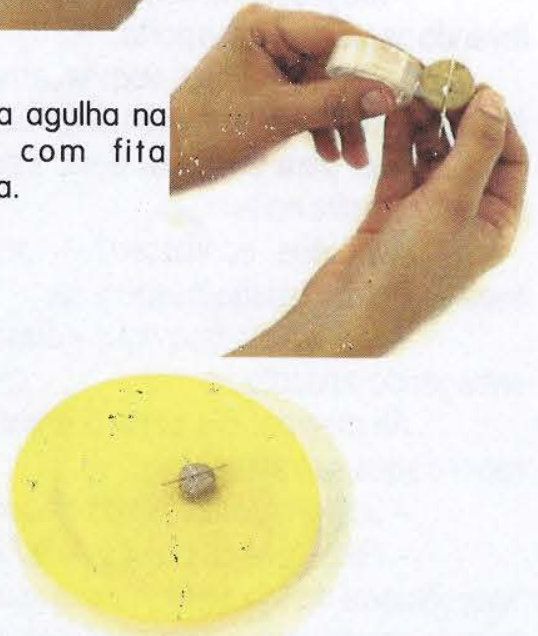

Encha um pires com água. Em seguida coloque a rolha com a agulha sobre a água e observe o que acontece.

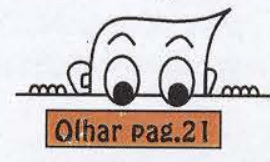

Os garotos montaram a bússola com bastante rapidez.

- Nossa! Que legal! - exclamou Patrícia. - Reparem, mesmo virando o pires ela continua apontando ao longo do mesmo sentido.

- Olhem! - exclamou Tales, fazendo uma demonstração. - A bússola fica "louca" quando eu aproximo o ímã.

- Muito bem, vocês fizeram tudo direitinho! - elogiou o professor. - A extremidade do ímã que aponta para o norte geográfico, é chamada de pólo norte magnético do ímã e a outra extremidade, de pólo sul magnético.

-Porquê? - questionou Patrícia.

-A Terra é um ímã gigantesco explicava o professor, fazendo desenhos.

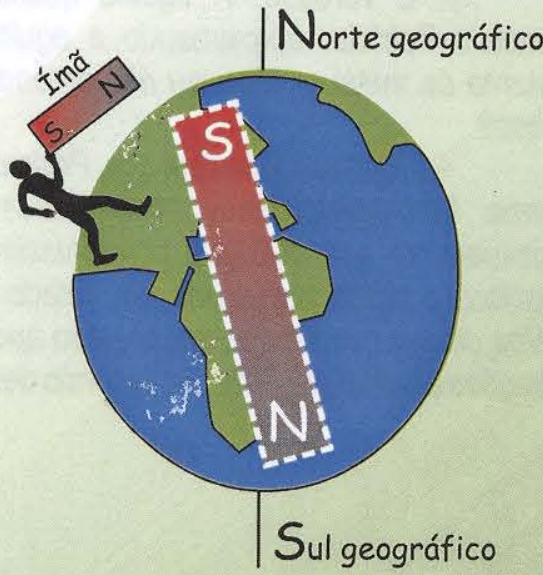

- Como vocês podem observar pelo desenho, o pólo norte geográfico é o pólo sul magnético da Terra.

- E o pólo sul geográfico é o pólo norte magnético da Terra - Tales continuou a explicação.

- Vale lembrar que o magnetismo da Terra é muito maior do que o da agulha magnetizada, permitindo dessa forma, que ela oriente a bússola-lembrou o professor.

- Professor, por que a bússola é tão utilizada na orientação? - questionou Pedro, logo em seguida.

- A vantagem de se usar uma bússola deve-se ao fato, do magnetismo da Terra ser considerado praticamente constante, isto é, ele não varia. Portanto, isso a torna um aparelho de boa precisão. 
- Antes que me perguntem quem descobriu a bússola - disse o professor, olhando para a Patrícia e sorrindo. - Acredita-se que os chineses passaram a idéia para os árabes e esses por sua vez para os europeus. Seu uso só se tornou possível em meados de 1300 , onde ela foi usada em viagens marítimas. Porém, a descoberta que a Terra comportava como um grande ímã, só ocorreu mais tarde por William Gilbert (1544 - 1603), que também se dedicou a estudaràs propriedades dos ímãs.

- Professor! Como eu desmagnetizo a agulha? - perguntou Marcelo, na primeira oportunidade.

- Basta levá-la ao fogo - respondeu ele mas tenham cuidado para não se queimarem.

Após a dica dada pelo professor eles foram verificar se realmente a agulha magnetizada perdia suas propriedades magnéticas ao ser aquecida.

- É verdade! A agulha desmagnetiza concluiu Patrícia, aproximando a agulha de uma estante de metal. - Mas, eu não entendi, o porquê disso?

- A agulha é feita com aço. Podemos dizer de forma bem simplificada, que esses materiais possuem na sua estrutura pequeníssimos ímãs explicou o professor. - Em seu estado natural, os pólos destes minúsculos ímãs, estão apontando em direções aleatórias-dizia ele, fazendo desenhos.

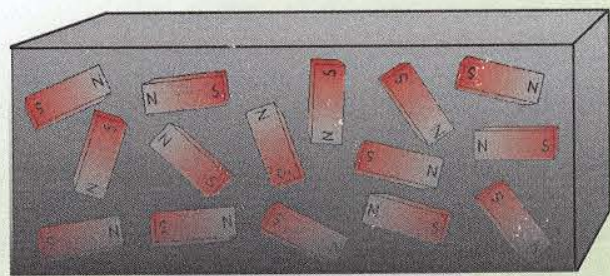

Representação microscópica de uma barra de ferro não imantada.
- Porém, quando a agulha é deixada próxima de um ímã, esses pequenos ímãs alinham-se, de modo que todos passam a apontar para a mesma direção, resultando na magnetização da mesma.

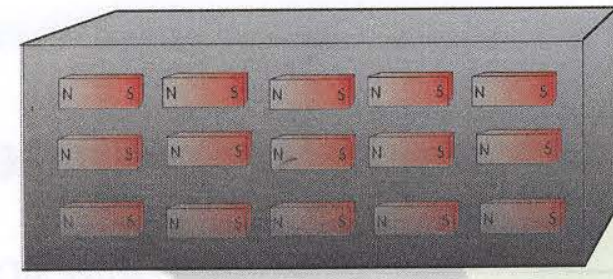

Representação microscópica de uma barra de ferro imantada.

- Ao aquecer a agulha vocês desordenam novamente esses pequenos ímãs e, consequentemente a agulha perde sua magnetização.

- Nossa! Preciso ir embora - lembrou Patrícia, após a explicação do professor.

- Vamos todos-avisou Pedro. - Professor, muito obrigado pela explicação.

- Me procurem sempre que precisar - ele avisou levando os garotos até a porta.

- Pessoal, nos vemos amanhã na casa de Marcelo - disse Patrícia, saindo apressadamente.

Mas para surpresa dela, Pedro foi a sua casa naquela mesma noite.

- O que aconteceu? - perguntou a garota, espantada com a visita inesperada.

- Vim trazer isso aqui - disse ele, timidamente, entregando o pacote.

Ali mesmo, ela abriu o embrulho, ansiosa para saber do que se tratava.

- Um livro de história da ciência! Adorei!

- Eu estava passando pela livraria e ao ver esse livro, lembrei-me de você - disse ele. - Mas não conte para os garotos que estive aqui hoje, porque você sabe... Eles irão ficar fazendo piadinhas sem graça.

- É uma pena - respondeu ela. - Adoraria contar para todos, sobre esse maravilhoso presente, mas se você prefere assim.

Páq.12 
- Já vou indo, está tarde - justificou ele. -Amanhã nos vemos!

Despediram-se com um beijo no rosto.

Pedro.

Naquela noite, ela adormeceu em cima do livro, tamanho era seu entusiasmo com o presente e a atitude de

No dia seguinte, eles reuniram-se novamente na casa de Marcelo.

- Pessoal! Ontem eu estava relembrando tudo que aprendemos até agora e, surgiu uma dúvida - comentou Pedro - nós aprendemos que a corrente elétrica produzida em um gerador, é causada pelo movimento de um ímã sobre um fio condutor, não é verdade? - e sem esperar a resposta dos colegas continuou. - Já o motor elétrico precisa de corrente elétrica para funcionar, como por exemplo o liquidificador. Eu não consigo entender a diferença entre esse dois aparelhos....-comentou Pedro.

- Eu acho que tenho a resposta para essa sua dúvida - disse Patrícia, abrindo o livro dado por Pedro. - Um professor de física dinamarquês chamado Hans Christian Oersted (1777 - 1851) em meados de 1819, dando uma aula, descobriu que um fio condutor quando percorrido por corrente elétrica, desviava a agulha magnética de uma bússola. Com isso, ele comprovou que cargas elétricas em movimento provocavam o aparecimento de um campo magnético. Mais tarde, tendo conhecimento desse fato, Faraday também mostrou que o campo magnético variável produzia corrente elétrica, como observamos na experiência de Faraday - ela lembrou os colegas da atividade já executada por eles e, complementou. - No final dessa história, o autor finaliza dizendo que esse é o príncipio de funcionamento do motor elétrico.

- Será que essa história é verdadeira? - duvidou Pedro.

-Poderíamos fazera mesma experiência! - sugeriu Tales, atento nas palavras da colega.

- Tales, tem razão - concordou Marcelo.- Assim saberemos se essa história é verdadeira.

E lá foram eles à montar novamente a bússola, ensinada pelo professor.

\section{Experiência de Oersted}

Você vai precisar de: $30 \mathrm{~cm}$ de cabinho, 1 pilha de 1,5V, 2 jacarés, 1 bússola e 1 suporte para uma pilha.

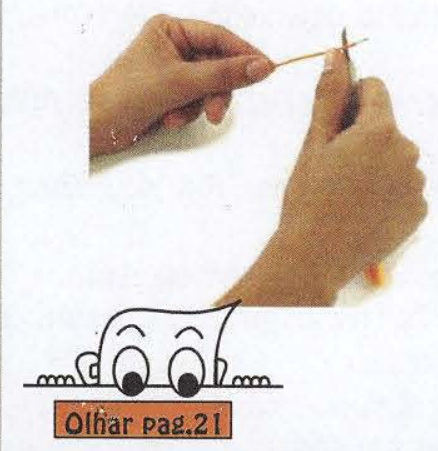

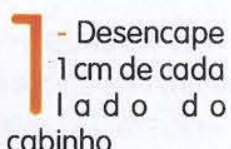

cabinho.

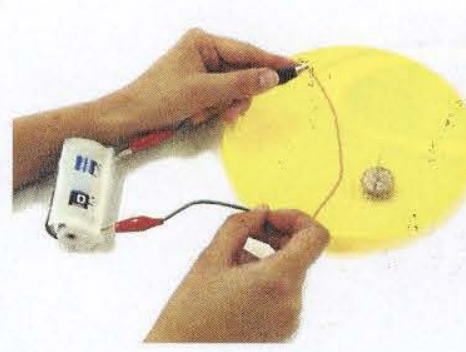

- Ligue 0 cabinho na pilha com os iacarés. Em seguida coloque 0 cabinho perto da bússola. Observe 0 movimento da agulha.

- Enquanto montavam a experiência, Marcelo perguntou a Patrícia onde ela tinha comprado aquele livro. Ela desconversou, mas ele percebeu que alguma coisa estava errada.

- Estranho! - exclamou Tales. - Alguma coisa está errada? A bússola não mexeu. 
- Deixe-me tentar? - pediu Pedro, colocando o cabinho preso a pilha, paralelo à agulha da bússola o contrário de Tales, que o tinha colocado perpendicular.

- Consegui! - gritou ele. - Realmente, quando passa corrente elétrica no fio a agulha da bússola movimenta-se.

- Porque? perguntou Tales.

- Vamos esquematizar o problema, quem sabe não entendemos o porquê disso - disse Patrícia, com papel e lápis na mão. - Primeiramente, sabemos que o campo magnético provoca uma força magnética sobre alguns materiais, como o ferro ou objetos magnetizados que se encontram imersos na sua região de atuação, não é mesmo!

E ela continuou sem esperar a resposta dos colegas.

- Observamos que a agulha não se moveu, quando colocamos o cabinho sobre ela, formando um ângulo de 90 graus.

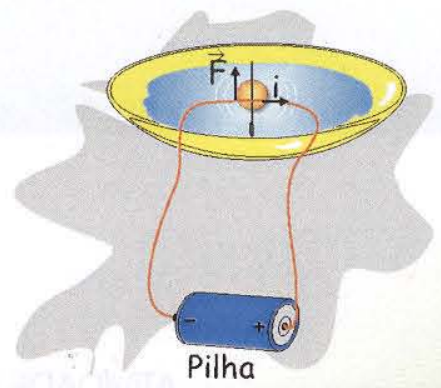

Já em qualquer outra posição ela se movimentou, porque a força magnética estava atuando na agulha.

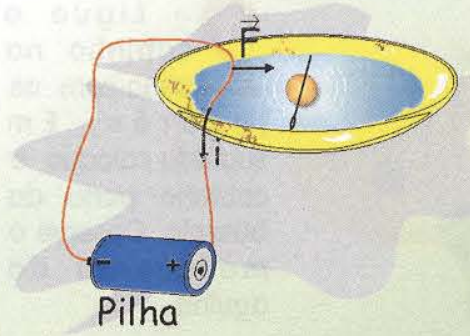

- Acho que você tem razão - comentou Marcelo. - Mas vamos enviar um e-mail para o site, para verificar se sua explicação está correta.

- Boa idéia! - disseram todos ao mesmo tempo.

Por sorte, a resposta não tardou a chegar.

\section{Garotos, suas conclusões estão corretas. Vocês sabiam que essa experiência é considerada uma} das maiores descobertas científicas, porque liga os fenômenos elétricos aos magnéticos, isto é, corrente elétrica gera campo magnético e campo magnético gera corrente elétrica.

Ah! Existe uma regra simples para determinar a direção da força magnética e do campo magnético, vocês poderão encontrá-la em livros textos de física.

- Hora do lanche! - gritou a mãe de Marcelo. Afinal "saco vazio não pára em pé".

- Pessoal! Vamos assistir um filme depois do lanche? - falava Marcelo, enquanto colocava cauda de chocolate sobre o sorvete.

- Ótima idéia-disse Patrícia.

Dali foram direto para a sala, onde passaram o resto da tarde.

- Esse filme foi muitolegal! - exclamou Pedro.

- Eu também gostei muito - comentou Patrícia. Vocês viram aquele aparelho gigantesco que atraia os robôs?

- É verdadel - concordou Pedro. - Mas é muito estranho um imã daquele tamanho!

- Nossa! Já anoiteceu - disse Patrícia, olhando pelajanela.- Preciso ir.

- Patricia, eu te acompanho - avisou Pedro.

Passaram-se três dias, para se reunirem novamente na casa de Marcelo.

- Vocês lembram daquele ímã enorme que vimos no filme? - recordou Pedro, ao chegar. - Meu pai disse que ele é chamado eletroímã.

- Vamos enviar um e-mail para o site perguntando como se constrói um! - sugeriu Marcelo.

- Boa idéia! - concordou Patrícia. - Por favor, faça isso Marcelo e pergunte também como ele foi descoberto.

Pág. 14 


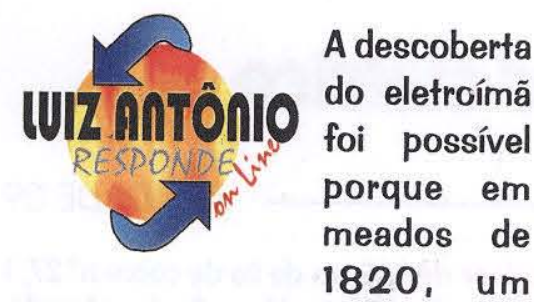

físico francês chamado André Ampère (1775 - 1836), demonstrou que um fio em espiral ou bobina, quando percorrido por uma corrente elétrica comportava-se como um ímã.

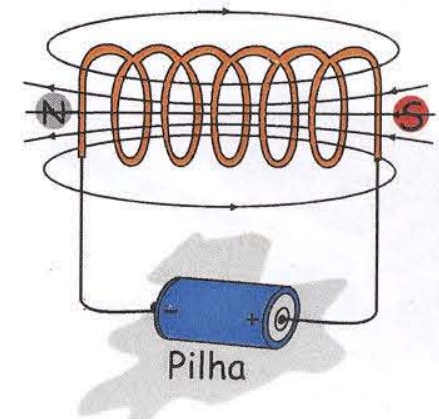

Pouco depois, William Sturgeon (1783 - 1850) descobriu que a força do eletroímã aumentava quando inseria uma barra de ferro no interior da bobina. Mais tarde, essa descoberta foi aperfeiçoada por Joseph Henry (1797 - 1878), fazendo um eletroímã capaz de levantar $1000 \mathrm{Kg}$.

Estou enviando uma atividade que ensina como construir um eletroímã.

\section{Transportador mą̧nético}

ATIVIDADE 08

Você vai precisar de: 1 pilha grande de $1,5 \mathrm{~V}$ com suporte, 1 prego grande de aproximadamente 6 $\mathrm{cm}, 2$ jacarés, fio de cobre $n$. $^{\circ} 37$, estilete, alfinete ou clipes

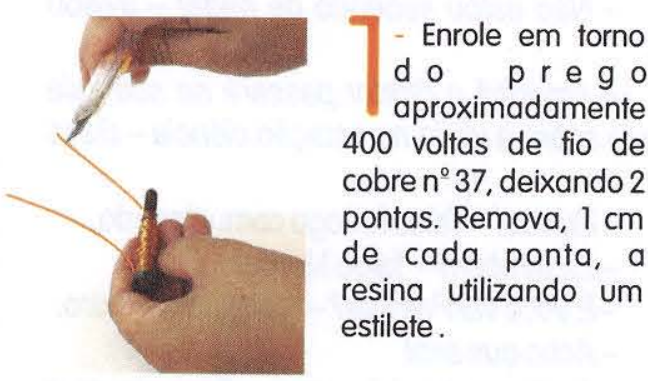

Utilize 2 jacarés para fixar as pontas do fio de cobre numa pilha.

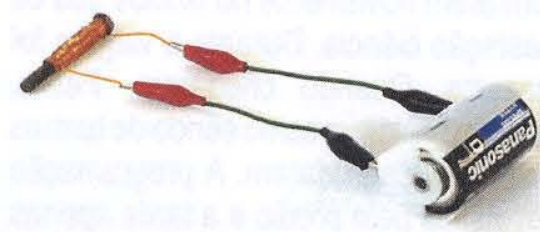

- Aproxime alfinetes ou clipes do fio de cobre enrolado no prego. Observe o que acontece com os alfinetes.

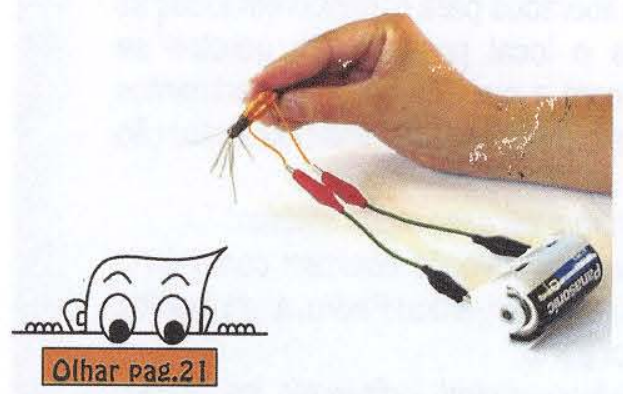

- Nossa uma tonelada! - exclamou Pedro. - Esse eletroímã de Henry era capaz de levantar o carro do meu pai, que pesa aproximadamente $500 \mathrm{Kg}$.

Enquanto os garotos conversavam, Patricia montava o eletroimã. 
- Que legal! A bobina atraiu os alfinetes! Reparem, quando eu desconecto a pilha os alfinetes caem. Porque?

- O fio enrolado quando percorrido por uma corrente elétrica comporta-se como um ímã. Nós já comprovamos isso na experiência de Oersted - lembrou Pedro. - Se você interrompera corrente elétrica, conseqüentemente o campo magnético cessa e os alfinete caem.

- Mudando um pouco o assunto, vocês vão à excursão da escola? - perguntou Patrícia.

- Não estou sabendo de nada! - avisou Pedro.

- Amanhã o diretor passará na sua sala avisando sobre a visita na estação ciência - disse ela.

- Eu vou! - Tales foi logo comunicando.

- Eu também - falou Marcelo.

- Evocê vai Patrícia? - perguntou Pedro.

-Acho que sim!

- Então, eu também vou - disse ele, com um belo sorriso.

No dia seguinte, o diretor passou em todas as salas convidando os alunos para a excursão. Os garotos confirmaram sua presença de imediato e se reencontraram novamente no ônibus que os levariam à estação ciência. Durante a viagem foi aquela algazarra. Quando chegaram, Pedro, Patrícia, Marcelo e Tales, mesmo sendo de turmas diferentes, não se desgrudaram. A programação constava em visitas pelo prédio e a tarde apenas palestras.

Primeiramente, um monitor contou-lhes toda a história da estação ciência e só depois os jovens foram liberados para conhecerem todas as atrações que o local possuía. Os garotos se encantaram com a quantidade de experimentos de física, mas um em especial chamou a atenção de Tales.

- Venham veresse motor elétrico!

- Muito jóia! Vocês ensinam como fazer um igual a esse? - perguntou Pedro, a um monitor que estava por perto.

- Ensinamos sim! - disse ele, apontando para uma sala. - Naquela sala estão todos os materiais necessários para a construção de alguns experimentos, e por sorte é possivel construir esse. Dêem uma olhada lá!

Os garotos não perderam tempo.

\section{Motor elétrico}

ATIVIDADE 09

Você vai precisar de: $55 \mathrm{~cm}$ de fio de cobre $\mathrm{n}^{2} 27,1$ pedaço de ímã de alto-falante, $15 \mathrm{~cm}$ fio de cobre de $1,5 \mathrm{~mm}^{2}$ (fio usado em instalação elétrica), fita crepe, 2 jacarés, 1 caixa de fósforo vazia, 1 pilha grande com suporte de 1,5 Vel alicate.

1 - Construa uma bobina móvel, enrolando 5 voltas de fio de cobre $n^{0} 27$ em torno de dois de seus dedos, deixando duas pontas livres de $2 \mathrm{~cm}$ de fio. Retire totalmente o verniz que recobre uma das pontas com o estilete. Na outra deixe uma faixa com verniz ao longo do comprimento e retire o resto.

Atençāo: O verniz deverá ser retirado corretamente, como foi proposto, para que o motor funcione.
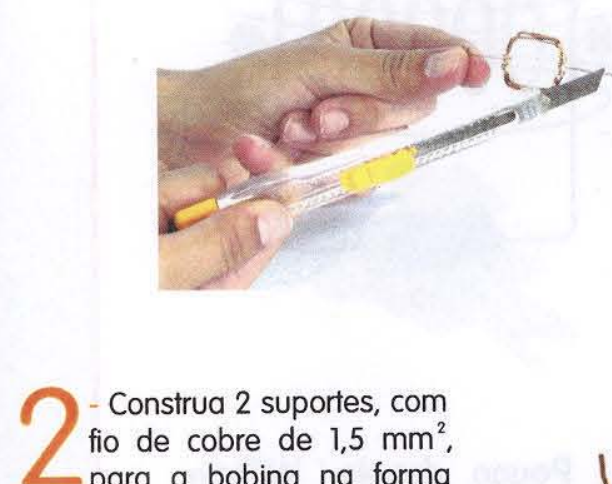

Construa 2 suportes, com fio de cobre de $1,5 \mathrm{~mm}^{2}$, para a bobina na forma mostrada. Pregue os anteparos nas laterais da caixa de fósforos. Em seguida raspe o local, onde a bobina será apoiada.
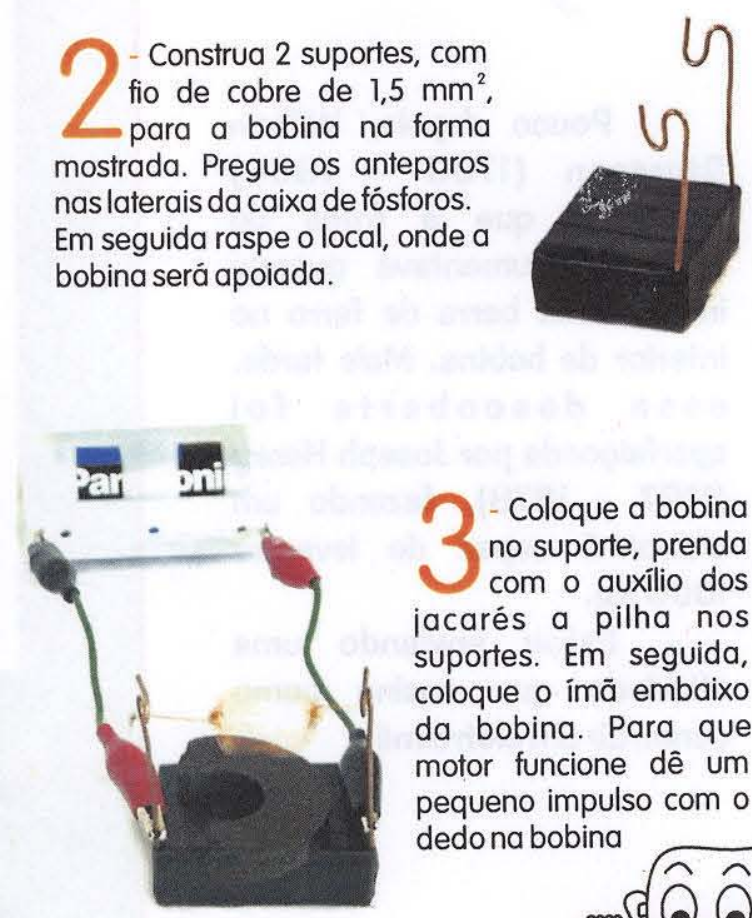

- Coloque a bobina no suporte, prenda com o auxilio dos jacarés a pilha nos suportes. Em seguida, coloque o ímã embaixo da bobina. Para que motor funcione dê um pequeno impulso com 0 dedona bobina

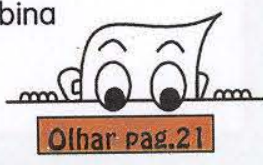

Páq. 16 
Na primeira tentativa o motor não funcionou porque eles não tinham raspado o verniz completamente de uma das pontas mas, com persistência, eles conseguiram fazê-lo funcionar.

- Que jóia! Está funcionando - disse Tales, com os olhos arregalados. O que está acontecendo?

- Parabéns! - elogiou a monitora aproximando dos garotos e, muito atenciosa, se prontificou a ajudá-los a entender o funcionamento do motor.

- Saibam que um fio condutor percorrido por uma corrente elétrica e imerso num campo magnético sofre a ação de uma força.

Fez uma pausa e continuou:

- Para facilitar o entendimento, vamos analisar o funcionamento do motor passo a passo. Separarei os processos que ocorrem no motor elétrico em 3 etapas:

1 - Na posição mostrada na figura abaixo, há contato entre a parte descascada do eixo da bobina e o suporte, possibilitando a passagem de corrente elétrica por ela. Como a bobina está imersa no campo magnético, gerado pelo ímã, isso provoca o aparecimento de forças que atuam sobre ela, fazendo-a girar.

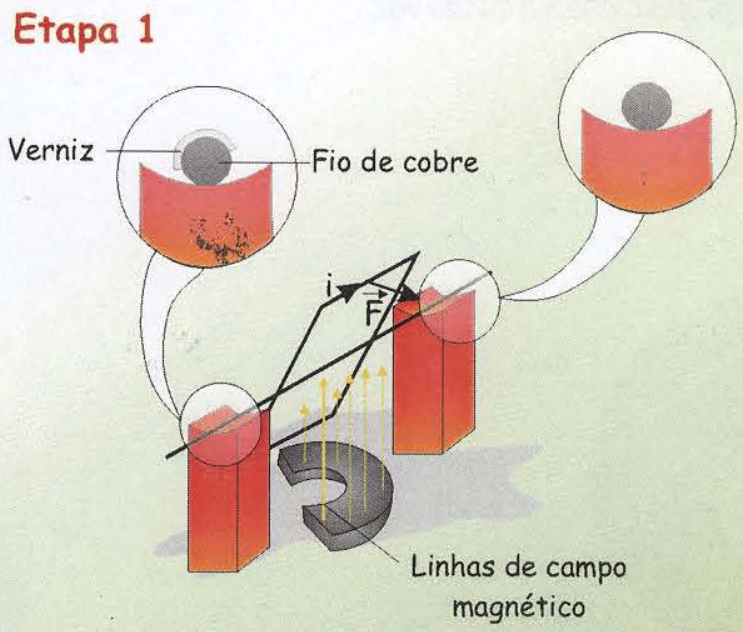

2-Ao girar, o eixo da bobina se apóia na faixa com verniz, que é isolante, interrompendo a passagem de corrente elétrica, mas ela continua movimentando por causa da inércia (propriedade que os corpos têm de não poderem, por si, alterar o seu estado de repouso ou o seu movimento).

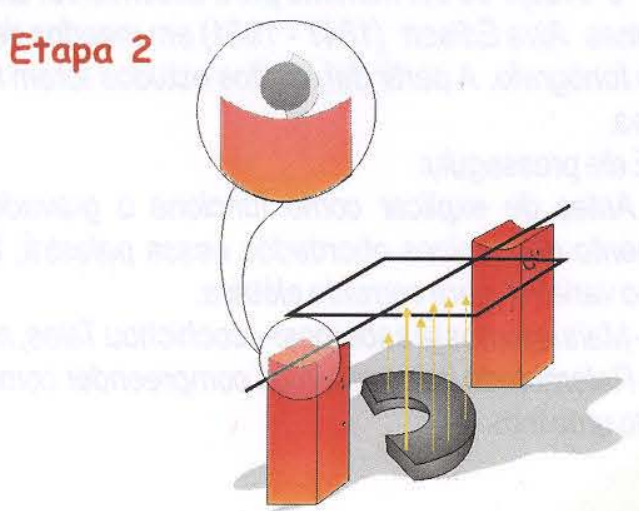

3- Porém, o contato entre a parte descascada do eixo da bobina e o suporte é novamente estabelecido, surgindo novamente as forças responsáveis por manter a bobina girando. Esses processos se repetem indefinidamente. Vocês entenderam?

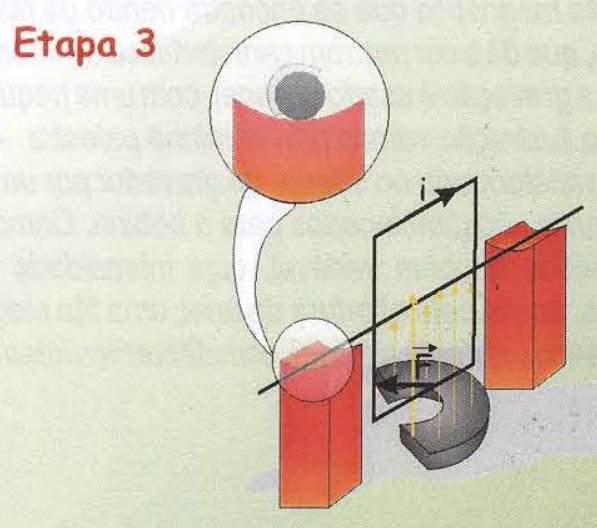

Todos fizeram um gesto com a cabeça dizendo que sim. Em seguida, eles agradeceram a monitora pela explicação e foram em busca de mais novidades. Pararam apenas para almoçar.

As atividades programadas para o período da tarde eram compostas por várias palestras, das quais os jovens poderiam escolher uma:

- Eu jă escolhi a palestra que vou assistir - disse Patrícia, olhando para a programação. - É essa aqui, "Aplicações do eletromagnetismo no cotidiano".

- Você tem razão, essa palestra tem tudo a ver com as nossas experiências recentes - concordou Pedro.

- Para o bem geral de todos, digo a vocês que eu também vou-brincou Tales.

Dali foram direto para o local da palestra. 
- O desejo do ser humano para desenvolver um aparelho que pudesse gravar sons em casa, foi concretizado com Thomas Alva Edison (1847 - 1931) em meados de 1880. Ele esboçou o primeiro aparelho que reproduzia o som, chamado fonógrafo. A partir daí, muitos estudos foram feitos para chegar ao gravador, sendo os alemães os pioneiros nessaárea.

Eele prosseguiu:

Antes de explicar como funciona o gravador, relembrarei alguns conceitos físicos importantes para o entendimento dos tópicos abordados nessa palestra, tais como: corrente elétrica gera campo magnético e, campo magnético variável gera corrente elétrica.

- Mais isso nósjá sabemos!-cochichou Tales, no ouvido de Patrícia.

- Relembrado isso, podemos compreender como são gravadas as informações em uma fita cassete - dizia ele, mostrando uma foto.

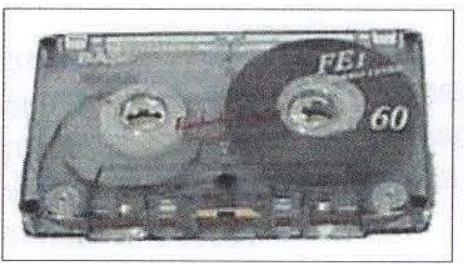

Fita cassete

- A fita magnética que se encontra dentro da fita cassete é composta por uma película plástica recoberta com óxido de ferro, que dá a cormarrom característica à maioria das fitas magnéticas.

Para a gravação é usado um anel, com uma pequena abertura, feito de aço, e nele é acoplada uma bobina.

Como ilustração vamos gravar minha palestra - dizia o professor, com o gravador na mão. - Quando eu falo, minha voz é transformada no interior do gravador por um circuito eletrônico em sinais elétricos, isto é, corrente elétrica variável, os quais são direcionados para a bobina. Como já é sabido, a corrente elétrica que percorre a bobina produz campo magnético também variável, cuja intensidade dependerá da corrente elétrica produzida pela minha voz. Enquanto isso, passa pela abertura do anel, uma fita magnética, com velocidade constante, a qual se magnetiza como campo magnético existente no local, com diferentes intensidades e proporcionais à minha voz.

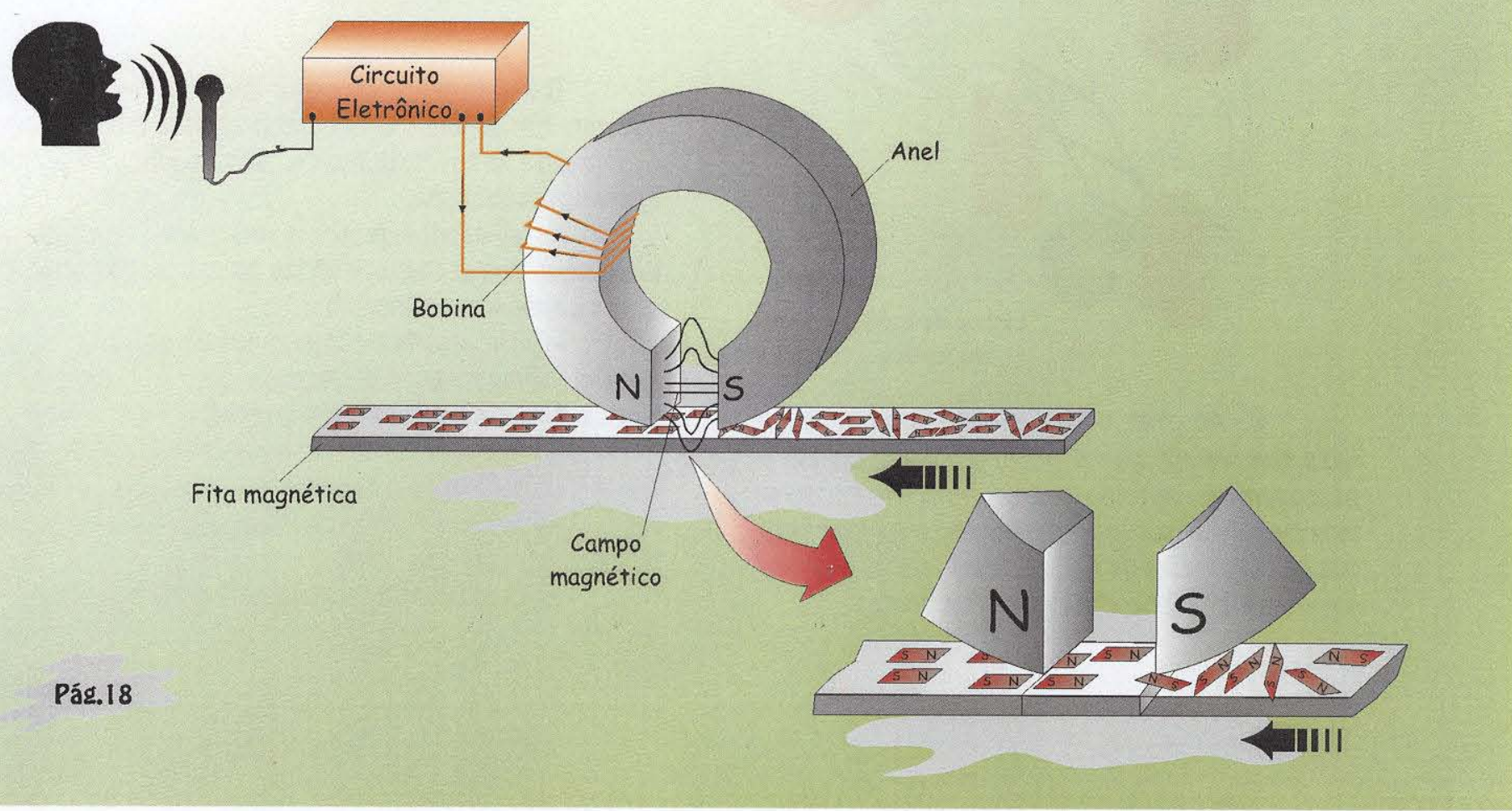


Portanto, o registro na fita magnética corresponde às mudanças ocorridas no campo magnético produzido pela corrente elétrica do que se quer gravar. Após esse processo, a fita magnética estará magnetizada e por consequência, minhas palavras estarãogravadas nela.

Agora, para ouvir as informações registradas na fita magnética, é necessário que ela passe por uma outra montagem semelhante à usada na gravação.

A fita magnetizada ao passar pela abertura do anel induzirá uma corrente elétrica na bobina, causada pela variação do campo magnético. Tais correntes elétricas são então amplificadas e reproduzem o sinal original quando repetidas em aparelhos como o alto-falante.

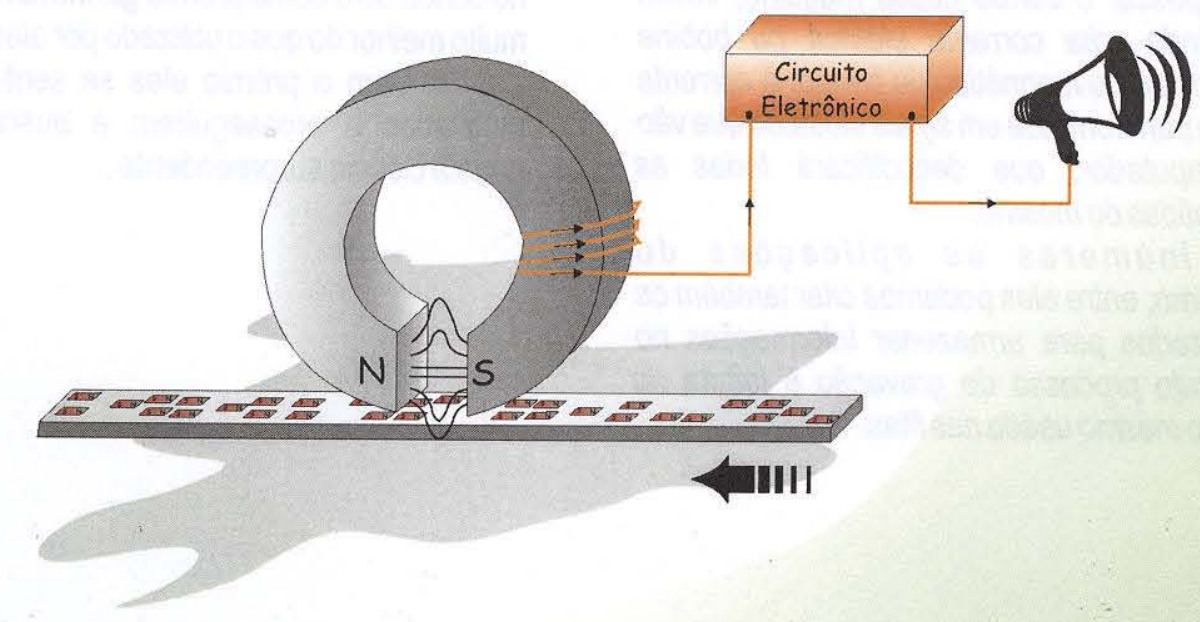

A fita magnética poderá gravar sons inúmeras vezes, porque a orientação dos pequenos imãs existentes nela, não é afetado no processo de reprodução.

Antes de terminar, quero homenagear Oersted e Faraday - dizia ele, enquanto mostrava a foto dos cientistas. Foram eles os primeiros a perceberem todos os fenômenos associados com a gravação de sons.

- Mas isso nós também já sabemos-Tales murmurou novamente no ouvido de Patrícia.

- Alguma pergunta? - perguntou o professor, após a explicação.

Como ninguém se manifestou, ele desafiou a plateia com uma pergunta.

- Já que vocês entenderam tudo! O que acontecerá com a fita magnetica gravada, se eu passar por ela um imã?

- Ela perderá a gravação no ponto onde houver contato com imã -respondeu Tales, rapidamente.

- Muito bem, jovem! Vejo que você aprendeu tudo.

Tales ficou todo convecido com o elogio do professor.

- Para terminar, começarei a segunda etapa fazendo uma pergunta. Por acaso, alguém aqui já viu um cartão como esse? - brincou o professor.

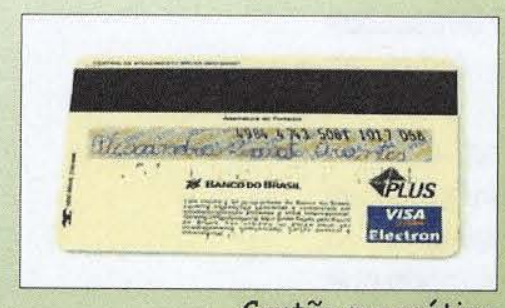

Cartão magnético

O pessoal deu risada.

- Era o que eu esperava, afinal atualmente eles estâo por toda parte. Ehoje eu irei explicar porque esses cartões são tão utilizados.

O principio de funcionamento do cartão magnético é semelhante ao do gravador de fitas. 
Todos os cartões magnéticos possuem uma faixa marrom no verso. Essa faixa é composta por um material magnético, na qual são gravadas todas as informações do portador, através de um código. Ao final da gravação essa faixa possuirá regiões magnetizadas e não magnetizadas.

A máquina utilizada para a leitura do cartão magnético possui uma bobina enrolada em um núcleo de ferro. Ao passar o cartão nessa máquina, vocês estarão induzindo uma corrente elétrica na bobina provocada pelo campo magnético do cartão. A corrente elétrica é então transformada em sinais elétricos que vão para um computador, que decodificará todas as informações obtidas do mesmo.

São inúmeras as aplicações do eletromagnetismo, entre elas podemos citar também os disquetes utilizados para armazenar informações no computador, cujo processo de gravação e leitura de informações é o mesmo usada nas fitas.

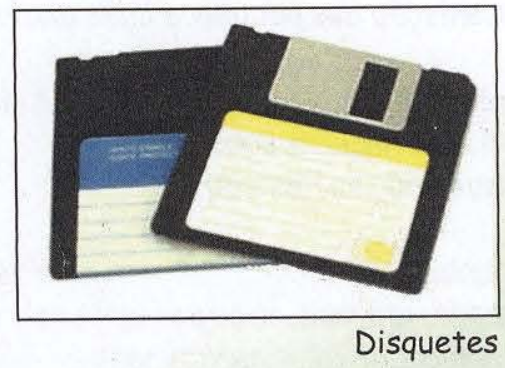

Pessoal, então por hoje é só, espero vê-los aqui novamente mês que vem, quando comemoraremos 10 anos de existência. Deixo avisado que haverá um evento denominado "O Cientista do Amanhã" onde serão premiados trabalhos científicos. Os interessados peguem na portaria um folheto com todas as informações.

Na saída os garotos não resistiram e foram conversar com o professor para obter mais informações sobre 0 concurso. Inicialmente, eles relataram 0 primeiro contato com a física e finalizaram falando que tinham feito alguns experimentos de eletromagnetismo com materiais simples e de baixo custo sob a orientação de um site e um professor. O professor ficou impressionado com as histórias contadas pelos garotos e incentivou-os a participar do evento.
Muito estimulados, eles confirmaram a presença e prometeram manter contato com 0 professor.

Passado um mês, lá estavam eles apresentando o trabalho na estação ciência. Foram dois dias muito cansativos para os garotos, porque contaram sua história para umas cinqüenta pessoas, mas valeu a pena, porque obtiveram o segundo lugar no concurso e como prêmio ganharam um computador muito melhor do que o utilizado por eles.

Com o prêmio eles se sentiram ainda mais motivados a prosseguirem a busca de respostas aquela ciência surpreendente .

\section{Páq.20}




\section{Lista de materiais}

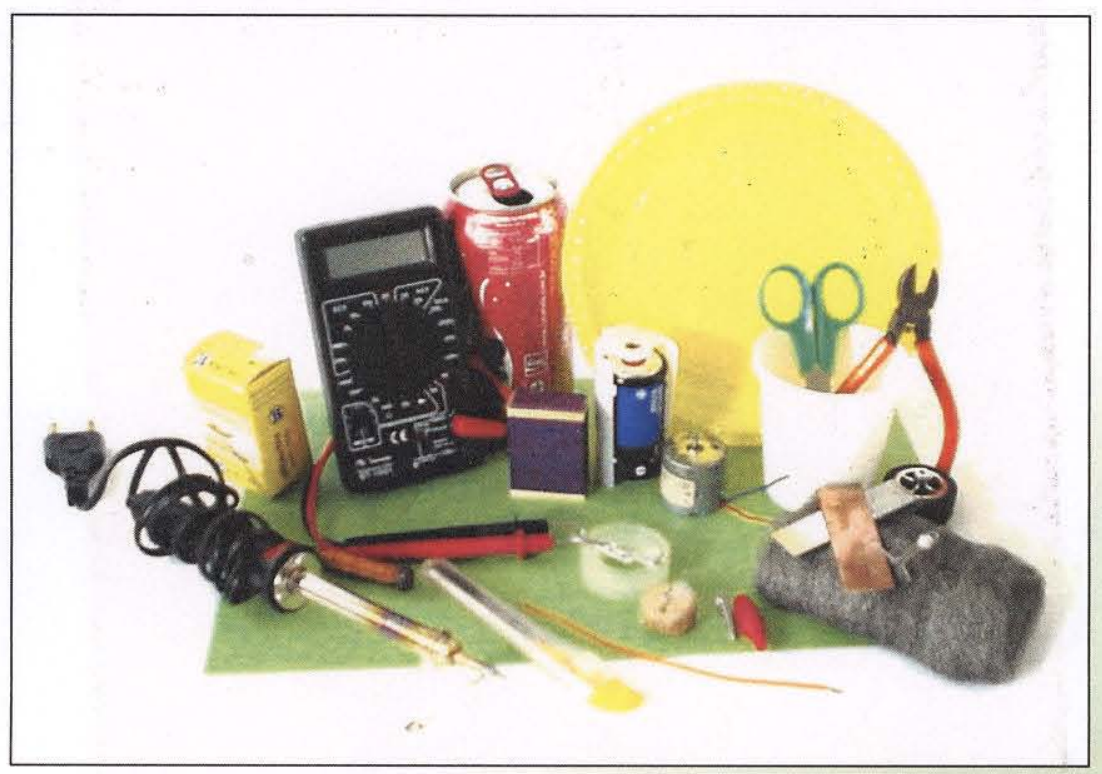

$\mathrm{Na}$ foto acima estão todos materiais necessários nas atividades propostas nesse fascículo. Primeiramente faremos algumas recomendações quanto ao uso deles e depois quando possível iremos propor outros materiais.

1- Os seguintes materiais: estanho, cabinho, garras tipo jacaré, soldador, pilha, led(vermelho), soquete são encontrados em lojas de artigos eletrônicos.

2- Chapas de cobre e zinco são encontradas em lojas que vendem calhas ou lojas de materiais ferrosos. É importante dizer que as chapas de zinco possuem apenas uma camada de zinco.

3- Sempre que vocês estiverem trabalhando com amperímetro, ligue-o, na escala 10A, para evitar que 0 aparelho estrague, caso haja uma corrente alta no circuito.

4-A limalha de ferro poderá ser trocada por bombril.

5-O prego poderá ser substituido por outro objeto de ferro.

6-0 fio de cobre utilizado para a construção do eletroímã não necessita ser n 37 , é recomendável que seja fino.

7-A agulha usada na construção da bússola é encontrada em lojas que vendem aviamentos para costura.

8-A caixa de fósforo pode ser substituída por uma base de madeira.

9. O motor elétrico é encontrado em carrinhos de brinquendo a pilha. 